\title{
On measurements of aerosol-gas composition of the atmosphere during two expeditions in 2013 along the Northern Sea Route
}

\author{
S. M. Sakerin ${ }^{1}$, A. A. Bobrikov ${ }^{2}$, O. A. Bukin ${ }^{2}$, L. P. Golobokova ${ }^{3}$, Vas. V. Pol'kin ${ }^{1}$, Vik. V. Pol'kin ${ }^{1}$, K. A. Shmirko ${ }^{4,5}$, \\ D. M. Kabanov ${ }^{1}$, T. V. Khodzher ${ }^{3}$, N. A. Onischuk ${ }^{3}$, A. N. Pavlov ${ }^{4}$, V. L. Potemkin ${ }^{3}$, and V. F. Radionov ${ }^{6}$ \\ ${ }^{1}$ V. E. Zuev Institute of Atmospheric Optics, Siberian Branch, Russian Academy of Sciences, Tomsk, Russia \\ ${ }^{2}$ Admiral G. I. Nevelsky State Marine University, Vladivostok, Russia \\ ${ }^{3}$ Limnology Institute, Siberian Branch, Russian Academy of Sciences, Irkutsk, Russia \\ ${ }^{4}$ Institute of Automatics and Control Processes, Far East Branch, Russian Academy of Sciences, Vladivostok, Russia \\ ${ }^{5}$ Far East Federal University, Vladivostok, Russia \\ ${ }^{6}$ Arctic and Antarctic Research Institute, St. Petersburg, Russia
}

Correspondence to: S. M. Sakerin (sms@iao.ru)

Received: 29 December 2014 - Published in Atmos. Chem. Phys. Discuss.: 22 June 2015

Revised: 21 September 2015 - Accepted: 23 October 2015 - Published: 10 November 2015

\begin{abstract}
We presented the results of expedition measurements of the set of physical-chemical characteristics of atmospheric aerosol in areas of the Arctic and Far East seas, performed onboard RV Akademik Fedorov (17 August22 September 2013) and RV Professor Khljustin (24 July7 September 2013). The specific features of spatial distribution and time variations of aerosol optical depth (AOD) of the atmosphere in the wavelength range of $0.34-2.14 \mu \mathrm{m}$ and boundary layer height, aerosol and black carbon mass concentrations, and disperse and chemical composition of aerosol are discussed. Over the Arctic Ocean (on the route of RV Akademik Fedorov) there is a decrease in aerosol and black carbon concentrations in a northeastern direction: higher values were observed in the region of Spitsbergen and near the Kola Peninsula; and minimum values were observed at northern margins of the Laptev Sea. Average $\operatorname{AOD}(0.5 \mu \mathrm{m})$ values in this remote region were 0.03; the aerosol and black carbon mass concentrations were 875 and $22 \mathrm{ng} \mathrm{m}^{-3}$, respectively. The spatial distributions of most aerosol characteristics over Far East seas show their latitudinal decrease in the northern direction. On transit of RV Professor Khljustin from the Japan Sea to the Chukchi Sea, the aerosol number concentration decreased on average from 23.7 to $2.5 \mathrm{~cm}^{-3}$, the black carbon mass concentration decreased from 150 to $50 \mathrm{ng} \mathrm{m}^{-3}$, and AOD decreased from 0.19 to 0.03 . We analyzed the variations in the boundary layer height, measured by ship-based lidar: the average value
\end{abstract}

was $520 \mathrm{~m}$, and the maximal value was $1200 \mathrm{~m}$. In latitudinal distribution of the boundary layer height, there is a characteristic minimum at a latitude of $\sim 55^{\circ} \mathrm{N}$. For water basins of eight seas, we present the chemical compositions of the water-soluble aerosol fraction (ions, elements) and small gasphase species, as well as estimates of their vertical fluxes. It is shown that substances are mainly (75-89\%) supplied from the atmosphere to the sea surface together with gas-phase species. The deposited ions account for from 11 to $24.5 \%$, and trace elements account for $0.2-0.4 \%$ of the total sum of water-soluble components. The average vertical fluxes of aerosol substance are a factor of 4-7 larger in the Japan Sea than in the water basins of Arctic seas.

\section{Introduction}

Studies of environment, including aerosol, in polar regions are urgent for two main reasons: (1) climate changes, which are most apparent just at high latitudes (Alekseev et al., 2011; Eisenman et al., 2007; IPCC, 2007); and (2) the development of the Arctic Basin. One of the most dynamical environmental components is aerosol, which plays an important role in radiative transfer and mass exchange processes in the continent-atmosphere-ocean system. The radiative processes are usually separated into direct and indirect effects of aerosol (Haywood and Boucher, 2000; Kondratyev, 2002 , 
2006). The direct radiative effects are manifested in the redistribution of scattered and absorbed solar radiation in the Earth's atmosphere. The indirect effects are associated with aerosol influence on the processes of cloud formation, cloud microphysical properties, rainfall, etc. (Twomey, 1977; Albrecht, 1989; Johnson et al., 2004).

Aerosol also substantially influences the processes of exchange of chemical compounds and elements between continent and ocean. Studies, performed by different authors, showed that transport of substances in aerosol composition via atmospheric channel is ranked second behind river discharge in significance (e.g., Shevchenko et al., 2000; Rahn, 1981). Transport of Saharan dust to the Atlantic Ocean (as far away as American coasts) by the trade wind, and the transport of Asian aerosol to Pacific and Indian oceans by monsoons, are examples of the most powerful continental flows.

As for air transports from Eurasia to high latitudes, they are unstable and less intense; however, the aerosol sources in the neighboring regions, i.e., in polar and mid-latitude zones, are very contrasting. On the one hand, aerosol that originates in the Arctic is practically absent because of snow-covered surfaces and low temperatures and insolation; on the other hand, the aerosol content is relatively high in the boreal zone and, especially, in industrially developed regions of Europe. Under the influence of various circulations, the Arctic atmosphere is enriched by aerosols of different types: smoke (forest fires), industrial, sulfate, organic, and other aerosols, including their absorbing component, black carbon (e.g., Vinogradova, 2014; Vinogradova and Veremeichik, 2013; Huang et al., 2010; Wang et al., 2011). The long-range meridional transports of aerosol substance occur predominately during winter and in the submicron particle size range. For this reason, situations with elevated aerosol turbidity of the atmosphere, known since last century as "Arctic haze", are observed in the winter-spring period.

Recent studies (Roiger et al., 2015; Law et al., 2014; Stohl et al., 2013, and references therein) have shown that a number of other factors, overlooked or underestimated in previous climate modeling, should be taken into consideration. Primarily, there had been an accelerated development of northern territories, associated with extraction and processing of mineral resources, combustion of petroleum gas in the regions of oil and gas production, and intensification of sea and air transportation. Climate changes (growth in temperature and duration of blocking anticyclones) gave rise to more frequent severe forest fires, leading to the formation of large masses of smoke aerosol and its transport to the Arctic (e.g., Stohl et al., 2006; Stone et al., 2008; Eck et al., 2009). For instance, in the boreal zone of Russia, large-scale events of extreme smoke haze were observed in 2002, 2010, and 2012 (e.g., Chubarova et al., 2012; Gorchakov et al., 2014; Kozlov et al., 2014). Moreover, aerosol-gas (including black carbon) emissions from heating systems in the cold period enhanced due to the development of the Arctic.
Thus, ever-growing emission of natural and anthropogenic aerosol in subarctic regions is added to far-range aerosol transport from Eurasia in the modern period. A consequence of all of the above is the change in radiative characteristics of the Arctic atmosphere (including clouds); while sedimentation of absorbing aerosol leads to a reduction in snow surface albedo, temperatures rise, and ice and snow melt, i.e., those processes of which roles are least studied at present (IPCC, 2013).

Even if ecological requirements are satisfied, the development of the Arctic shelf and the Northern Sea Route will elevate the aerosol-gas loading to at least some degree, and will lead to additional effects which are still difficult to predict due to data shortage. Therefore, it is important to have more complete information on the present-day state of the Arctic atmosphere, even at the initial stage, and to subsequently control its dynamics.

The aerosol observations are most long-term at the Arctic stations in Barrow (Alaska), Alert (Canada), Ny-Ålesund and Hornsund (Spitsbergen), and Sodankylä (Finland). The obtained results were reviewed in other studies (Tomasi et al., 2007, 2012). The characteristics of the Arctic aerosol were extensively studied by Russian scientists on a few high-latitude islands and at North Pole drifting stations in the 1970s-1990s (Radionov et al., 1994; Radionov and Marshunova, 1992; Tomasi et al., 2007). The results of the studies of polar aerosol in the next decade were summarized in a reviewing monograph (Shevchenko, 2006).

The geography of aerosol studies in polar and subpolar regions of Russia has been substantially extended in recent years. In 2003-2007, a few cycles of expedition measurements of microphysical and chemical composition of aerosol were performed onboard research vessels in water basins of the White and Kara seas (Pol'kin et al., 2007, 2011a; Golobokova et al., 2013). Regular observations of the aerosol optical depth (AOD) of the atmosphere in the regions of Tiksi (since 2010) and Yakutsk (since 2004) (Sakerin et al., 2005) were initiated with the use of the AERONET network CE318 Sun-sky radiometer. Integrated studies of aerosol characteristics at the Russian polar station in Barentsburg (Spitsbergen) were resumed (Sakerin et al., 2012; 2014).

In the summer of 2013, the aerosol characteristics were measured in two Arctic cruises of research vessels (RV) Akademik Fedorov and Professor Khljustin. The physicalchemical characteristics of aerosol seem to be obtained for the first time within a relatively short (about 1 month) time interval along the entire Northern Sea Route from Arkhangelsk to Vladivostok. The main results of these studies are discussed in this work. These studies allowed us to ascertain the optical and microphysical aerosol characteristics in the present-day period. The AOD value in an extended wavelength range of $0.34-2.14 \mu \mathrm{m}$ was determined for the first time. Quantitative data on the decrease of AOD and aerosol concentration during the warm period (polar day) were obtained. At the same time, we noted opposite seasonal 
variations in the mass concentration of black carbon (with a larger concentration during summer than in spring). The elevated concentrations of black carbon during the summer period seem to be due to a blowout of coarsely dispersed particles of coal origin from the bared underlying surface.

\section{Characterization of expedition measurements}

The route of RV Akademik Fedorov (Fig. 1) followed predominately in a latitudinal direction: from Arkhangelsk to Kirkenes across the White and Barents seas, and then across the Arctic Ocean to northeastern margins of the Laptev Sea and back. The route of RV Professor Khljustin followed in the meridional direction from Vladivostok to the Bering Strait and then westward up to the port of Pevek (East Siberian Sea). The total periods of measurements were from 17 August to 2 September (2013) onboard RV Akademik Fedorov and from 24 July to 7 September (2013) onboard RV Professor Khljustin. The research program included the measurements of microphysical characteristics and chemical composition of aerosol in the near-ground layer, spectral AOD, and water vapor content of the atmosphere. The height of the atmospheric boundary layer was additionally measured onboard RV Professor Khljustin.

The measurements of AOD $\left(\tau^{\mathrm{a}}\right)$ and water vapor content $(W)$ of the atmosphere were performed using portable Sun photometers, SPM, operating in the wavelength range of 0.34-2.14 $\mu \mathrm{m}$ (Sakerin et al., 2013). The main technical characteristics of SPM are presented in Table 1. The measurements of direct solar radiation in the atmospheric "transparency windows" were used to calculate the spectral AOD and the parameters $\alpha, \beta$ of Angström formula, which well describes the wavelength dependence of AOD in the wavelength region of $\sim 0.3-1 \mu \mathrm{m}$ :

$\tau^{\mathrm{a}}(\lambda)=\beta \cdot \lambda^{-\alpha}$,

where $\lambda$ is the wavelength.

The measurements in the IR wavelength range (1.2$2.14 \mu \mathrm{m}$ ) made it possible to extract the coarsely dispersed AOD component $\tau^{\mathrm{c}}$, caused by quasi-neutral attenuation of radiation by large particles (larger than $1 \mu \mathrm{m}$ ), as well as the selective finely dispersed AOD component $\tau^{\mathrm{f}}(\lambda)$. For instance, in the region of $0.5 \mu \mathrm{m}: \tau^{\mathrm{f}}(0.5)=\tau^{\mathrm{a}}(0.5)-\tau^{\mathrm{c}}$.

The total water vapor content of the atmosphere was determined on the basis of differential methods according to the data of measurements in the water vapor absorption band $(0.94 \mu \mathrm{m})$ and in the neighboring "transparency window" of $0.87 \mu \mathrm{m}$. The methods for determining AOD (including $\tau^{\mathrm{c}}$, $\tau^{\mathrm{f}}$ ) and water vapor content of the atmosphere, as well as the results of their analysis in different ocean regions, were considered in more detail in other works (Kabanov et al., 2009; Sakerin and Kabanov, 2002; Sakerin et al., 2008).

The microphysical characteristics of aerosol in the nearground atmospheric layer were determined using two sets of

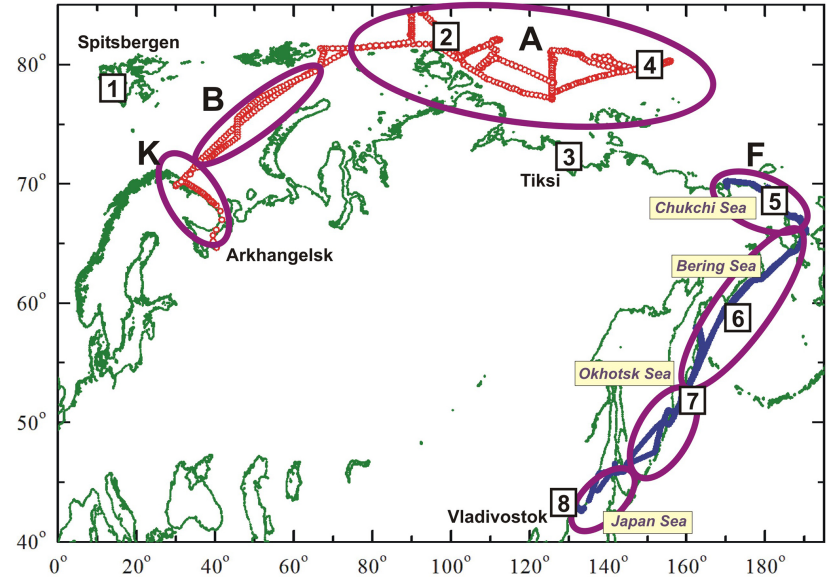

Figure 1. Map of the routes of Arctic cruises of RV Akademik Fedorov and Professor Khljustin. Numbers indicate the regions where AOD values were calculated; letters and ovals indicate the sections of the routes within which the aerosol microphysical parameters were determined.

instrumentation (Kozlov et al., 2010), comprising the photoelectric particle counters and aethalometers (see Table 1).

The mass concentration of absorbing substance (black carbon, BC) in the composition of aerosol particles $M_{\mathrm{BC}}$ $\left(\mu \mathrm{g} \mathrm{m}^{-3}\right)$ was measured with the MDA-02 aethalometer at the wavelengths of $0.46,0.53,0.59$, and $0.63 \mu \mathrm{m}$ developed by IAO SB RAS (Kozlov et al., 2008, 2014). The concentration sensitivity of the aethalometer at $30 \mathrm{~L}$ of air pumped through the optical cell was about $10 \mathrm{ng} \mathrm{m}^{-3}$. The aethalometer was calibrated under laboratory conditions through comparison of the data of synchronous optical and gravimetric measurements with a pyrolysis generator of soot particles. Additionally, intercalibration measurements of BC mass concentrations were performed with a MAAP-5012 aethalometer (Thermo Fisher Scientific Inc., Franklin, TN, USA).

The mass $M_{\mathrm{A}}\left(\mathrm{ng} \mathrm{m}^{-3}\right)$ and number $N_{\mathrm{A}}\left(\mathrm{cm}^{-3}\right)$ concentrations of aerosol particles with diameters from 0.3 to $20 \mu \mathrm{m}$ were determined with the help of photoelectric particle counters GRIMM 1.108 (Peters et al., 2006; Grimm and Eatough, 2009) and AZ-10 (Manual AZ-10, 2010), which were calibrated under factory conditions with the help of polystyrene latexes with known sizes. The intercalibration of photoelectric counters, performed before the expeditions, confirmed that data compare well within the uncertainties of the instruments.

The samples of the studied air were taken through silicon hoses with lengths up to $1 \mathrm{~m}$ for aethalometers and up to $0.5 \mathrm{~m}$ for particle counters. The heights of air sampling above the sea surface level were about $8 \mathrm{~m}$ onboard RV Professor Khljustin and $20 \mathrm{~m}$ onboard RV Akademik Fedorov. The aerosol parameters were measured round-the-clock, with the periodicity of the measurement cycles of $1 \mathrm{~h}$ and a duration of 10 to $30 \mathrm{~min}$, depending on the total particle con- 
Table 1. Brief characteristics of instruments in aerosol complex.

\begin{tabular}{|c|c|c|}
\hline \multirow[t]{2}{*}{ Instruments } & \multicolumn{2}{|c|}{ Main characteristics } \\
\hline & RV Akademik Fedorov & RV Professor Khljustin \\
\hline \multirow[t]{2}{*}{ SPM Sun photometers } & \multicolumn{2}{|c|}{$\begin{array}{c}\text { AOD and water vapor content of the atmosphere with uncertainties of } 0.01-0.02 \\
\text { and } 0.1 \mathrm{~g} \mathrm{~cm}^{-2} \text {, respectively. Field of view angle is } 1.5-2.5^{\circ} \text {. Passband maxima of } \\
\text { filters are at }\end{array}$} \\
\hline & $\begin{array}{l}381,373,405,500,550,673,775,870 \\
933,1045,1249,2132 \mathrm{~nm}\end{array}$ & $\begin{array}{l}341,367,439,501,547,676,777,871 \\
938,1044,1553,2136 \mathrm{~nm}\end{array}$ \\
\hline \multirow[t]{2}{*}{ Particle counters } & GRIMM 1.108. & $\mathrm{AZ}-10$ \\
\hline & $\begin{array}{l}\text { Particle number and mass concen- } \\
\text { trations in } 15 \text { size ranges from } 0.3 \\
\text { to } 20 \mu \mathrm{m}: 0.3-0.4 ; 0.4-0.5 ; 0.5-0.65 \\
0.65-0.8 ; 0.8-1.0 ; 1.0-1.6 ; 1.6-2.0 ; \\
2.0-3.0 ; 3.0-4.0 ; 4.0-5.0 ; 5.0-7.5 ; 7.5- \\
10 ; 10-15 ; \text { and } 15-20 \mu \mathrm{m} \text {. Tolerance } \\
\text { ranges: count correlation at } 1 \mu \mathrm{m} \pm 5 \% \text {; } \\
\text { relative mass deviation } \pm 5 \% \text { to refer- } \\
\text { ence unit. }\end{array}$ & $\begin{array}{l}\text { Particle number and mass concentra- } \\
\text { tions in six diameter ranges from } 0.3 \text { to } \\
10 \mu \mathrm{m}: 0.3-0.4 ; 0.4-0.5 ; 0.5-1.0 ; 1.0- \\
2.0 ; 2.0-5.0 ; \text { and } 5.0-10 \mu \mathrm{m} . \\
\text { Tolerance ranges: } \pm 30 \% \text {. }\end{array}$ \\
\hline Aethalometers (Kozlov et al., 2008) & \multicolumn{2}{|c|}{$\begin{array}{l}\text { Mass concentration of black carbon in particles of submicron range. } \\
\text { Sensitivity is } 10 \mathrm{ng} \mathrm{m}^{-3}\end{array}$} \\
\hline The vacuum diaphragm pump HBM 1.2 & Bleeding the air at a $\mathrm{s}$ & eed of $0.02 \mathrm{~m}^{3} \mathrm{~min}^{-1}$ \\
\hline $\begin{array}{l}\text { One-frequency polarization lidar } \\
\text { (Bukin et al., 2007; Shmirko et al., } \\
\text { 2010) }\end{array}$ & & $\begin{array}{l}\text { S- and p-polarization of backscattered } \\
\text { signal was recorded with a spatial res- } \\
\text { olution of } 1.5 \mathrm{~m} \text { along a laser beam. } \\
\text { Maximal height of sounding was about } \\
4000 \mathrm{~m} \text { in the daytime and about } \\
5000 \mathrm{~m} \text { at nighttime. Temporal resolu- } \\
\text { tion of recorded profiles was approxi- } \\
\text { mately } 7 \mathrm{~s} \text {. }\end{array}$ \\
\hline $\begin{array}{l}\text { Automated meteorological complex } \\
\text { AMK-03 (http://meteosap.ru) }\end{array}$ & & $\begin{array}{l}\text { Meteorological parameters: } \\
\text { air temperature }(T) \text {; relative humidity } \\
\text { of air }(\mathrm{RH}) \text {; atmospheric pressure }(P) \text {; } \\
\text { horizontal wind speed (WS) and wind } \\
\text { direction; and vertical wind speed }(w) \text {. }\end{array}$ \\
\hline
\end{tabular}

centration. The process of measurements is automated: it is performed in a programmatically specified mode, with data being saved to files on a computer. Processing was performed by sorting out separate measurements, distinctly burdened by the effect of local sources of aerosols of anthropogenic origin (exhausts from pipes of internal combustion engines, ventilation shafts, etc.). Sometimes, 20-30\% of the total data volume was sorted out with respect to separate parameters.

About $8001 \mathrm{~h}$ cycles of $M_{\mathrm{A}}, N_{\mathrm{A}}$, and $M_{\mathrm{BC}}$ measurements were performed onboard RV Akademik Fedorov for 30 days of measurements. After sorting, $72 \%$ of $M_{\mathrm{A}}, N_{\mathrm{A}}$ values and $50 \%$ of $M_{\mathrm{BC}}$ values were left for analysis. About 900 measurement cycles were performed onboard RV Professor Khljustin for 46 days. A total of $77 \%$ of $M_{\mathrm{A}}, N_{\mathrm{A}}$ values and $67 \%$ of $M_{\mathrm{BC}}$ values were left for analysis after sorting out.

Samples of aerosol and gas admixtures for chemical analysis were collected on filter packs with the use of the filterpack method, adopted in international monitoring networks
(EMEP, 1996). The total aerosol of coarsely and finely dispersed fractions was accumulated on PTFE filters (Teflon, Japan) with pore diameters of $0.8 \mu \mathrm{m}$ (filter no. 1). The gas admixtures $\left(\mathrm{SO}_{2}, \mathrm{HCl}, \mathrm{NO}_{x}, \mathrm{NH}_{3}\right)$ were collected on polyamide filter ULTIPOR $\mathrm{N}$ with pore diameter of $0.45 \mu \mathrm{m}$ (filter no. 2) and Whatman ${ }^{\circledR}$ cellulose filter papers, impregnated with an alkaline solution (filter no. 3) and an acid solution (filter no. 4).

In aqueous extracts of filter no. 1, we determined the water-soluble fraction of aerosol substance, i.e., the ions of calcium $\left(\mathrm{Ca}^{2+}\right)$, magnesium $\left(\mathrm{Mg}^{2+}\right)$, sodium $\left(\mathrm{Na}^{+}\right)$, potassium $\left(\mathrm{K}^{+}\right)$, ammonium $\left(\mathrm{NH}_{4}^{+}\right)$, and nitrate $\left(\mathrm{NO}_{3}^{-}\right)$, chloride $\left(\mathrm{Cl}^{-}\right)$, and sulfate $\left(\mathrm{SO}_{4}^{2-}\right)$ ions. The analysis was performed by a ion chromatography method on the ion chromatography system ICS-3000 (Dionex, USA) (ICS-3000 Ion, 2008). The method of mass spectrometry with inductively coupled plasma on the Agilent 7500ce device (USA) was used to determine the content of water-soluble microelements $\mathrm{Al}, \mathrm{Ti}$, V, Cr, Fe, Co, Ni, Cu, Zn, As, Se, Mo, Cd, Sb, Pb, Ba, Be, B, 
$\mathrm{Li}, \mathrm{Mn}, \mathrm{Sr}$, and U. In aqueous extracts of filter no. 2, we measured the concentrations of ions $\mathrm{SO}_{4}^{2-}, \mathrm{Cl}^{-}, \mathrm{NO}_{3}^{-}$, and $\mathrm{NH}_{4}^{+}$ with a subsequent recalculation to give $\mathrm{SO}_{2}, \mathrm{HCl}, \mathrm{HNO}_{3}$, and $\mathrm{NH}_{3}$; and in aqueous extracts of filter no. 4 we measured the concentrations of ion $\mathrm{NH}_{4}^{+}$, recalculated to give $\mathrm{NH}_{3}$. The exposed filter no. 3 was extracted by $0.05 \%$ hydrogen peroxide $\left(\mathrm{H}_{2} \mathrm{O}_{2}\right)$ with a subsequent determination of concentration of ion $\mathrm{SO}_{4}^{2-}$ in the extract with recalculation to give $\mathrm{SO}_{2}$ (EMEP, 1996). Before chemical analysis, all samples were filtered through an acetate filter (Vladisart, Russia) with a pore diameter of $0.2 \mu \mathrm{m}$.

Aerosols were accumulated on filters for $8-10 \mathrm{~h}$ using air pumps (see Table 1). The air analyzed was taken through a silicon hose with a diameter of $5 \mathrm{~mm}$. The effect of the ship engine exhaust plume was eliminated through a constant control of wind direction and synchronization of measurements with meteorological parameters obtained from meteorological station. In all, 38 samples of aerosols and gas admixtures were collected during expedition onboard RV Professor Khljustin, and 18 samples onboard RV Akademik Fedorov.

We note that the reliability of chemical analysis results, obtained with these methods and instruments, was repeatedly confirmed through participation in data quality control (QA/QC) as part of international programs (http://www.qasac-americas.org; http://www.acap.asia/ interlab/os/; http://www.nilu.no; http://kvina.niva.no/intercomparison2). The obtained data largely deviate from true values by no more than $10-15 \%$, indicating the high quality of personnel and reliability of the results.

In addition to aerosol characteristics, the height of the atmospheric boundary layer (BL) was measured in the expedition cruise of Professor Khljustin with the help of onefrequency polarization lidar (see Table 1). The receiver system of lidar comprised a Maksutov system $150 \mathrm{~mm}$ telescope, coupled with a Hamamatsu R7400 photomultiplier tube (PMT) and high-speed two-channel analog-todigital converter (ADC) of LA-n10-12USB-U trademark (http://www.rudshel.ru/board_with_USB.html). The Quantel Brilliant-Ultra Nd:YAG laser (http://www.lambdaphoto.co. uk/pdfs/Ultra.pdf) with the generator of second harmonics was used as transmitter. The full overlap range was $80 \mathrm{~m}$. The BL height was measured in the absence of dense low-level clouds, under calm sea conditions three times a day: in the morning (08:00 UTC + 11), at dinnertime (13:00 UTC + 11), and in the evening $(22: 00$ UTC +11$)$ hours. One time measurement series lasted for about $8 \mathrm{~min}$, during which we recorded 80 profiles at a laser pulse repetition rate of $20 \mathrm{~Hz}$. The backscattered signal with parallel and perpendicular polarizations was recorded by accumulating 100 shots. The measurements were performed along the slant path with a zenith angle of $42^{\circ}$. Each measurement series was accompanied by a recording of the profile, obtained with a closed telescope, to correctly account for the background signal and various induced noises.
The optical experiments onboard Professor Khljustin were supplemented by measurements of meteorological parameters with the help of the AMK-03 automated meteorological complex (see Table 1). The meteorological complex makes it possible to measure the air temperature with the uncertainty of $\pm 0.3{ }^{\circ} \mathrm{C}$ at temperature $T<|30|^{\circ} \mathrm{C}$, and with the uncertainty of $\pm 0.5^{\circ} \mathrm{C}$ at temperature $T>|30|^{\circ} \mathrm{C}$, with working temperatures ranging from -50 to $+50^{\circ} \mathrm{C}$; the horizontal wind speed WS in the range from 0.1 to $40 \mathrm{~m} \mathrm{~s}^{-1}$ with uncertainty of $\pm(0.1+0.02 \cdot \mathrm{WS}) \mathrm{m} \mathrm{s}^{-1}$; the horizontal wind direction with uncertainty of $\pm 2^{\circ}$; the vertical wind speed $w$ in the range from -15 to $15 \mathrm{~m} \mathrm{~s}^{-1}$ with uncertainty of $\pm(0.1+0.02 w) \mathrm{m} \mathrm{s}^{-1}$; the relative humidity (RH) of air in the range from 15 to $100 \%$ with uncertainty of $\pm 2.5 \%$ at $T>0$, and with uncertainty of $\pm 5 \%$ at $T \leq 0$; and the atmospheric pressure in the range from 693 to $1067 \mathrm{hPa}$ with uncertainty of $\pm 1 \mathrm{hPa}$.

The data of back trajectory analysis were provided by the Hybrid Single Particle Lagrangian Integrated Trajectory model (https://ready.arl.noaa.gov/HYSPLIT.php). The boundary layer height was calculated from meteorological parameters, using reanalysis data of European Center for Medium-Range Weather Forecasts (ECMWF, http: //data-portal.ecmwf.int/).

\section{Atmospheric AOD and boundary layer height}

\subsection{Specific features of spatial distribution of AOD and water vapor content of the atmosphere}

Sun photometer measurements of atmospheric AOD are difficult to make at Arctic latitudes due to the low elevation (or absence) of the Sun for a considerable part of the year, severe weather conditions, clouds, and fog. Therefore, data of coastal observations for the same period of time in Barentsburg (Spitsbergen), Tiksi, and Vladivostok were included in the analysis of ship-based measurements to gain a more complete understanding of AOD along the route of expeditions.

The AOD measurements were performed using an SPM photometer in Barentsburg and an SP-9 photometer in Vladivostok (Sakerin et al., 2013); and the AOD measurements in the region of Tiksi were performed using the CE 318 Sunsky radiometer (AERONET), operating in the wavelength range of $0.34-1.02 \mu \mathrm{m}$ (Holben et al., 1998). The coordinates of the main regions and periods of measurements are presented in Table 2. The total period of photometric observations was 21 August-14 September 2013.

The average characteristics of atmospheric depth, calculated for different maritime regions, are presented in Table 3 and in Fig. 2. Comparative analysis of data obtained led to the following conclusions. In the Arctic zone, higher values of spectral AOD and water vapor content of the atmosphere were observed in the region of Barentsburg: for instance, the average values were $\tau_{0.5}^{\mathrm{a}}=0.053$ in the visi- 
Table 2. Geographic positions of regions and periods of Sun photometer measurements.

\begin{tabular}{cllll}
\hline $\begin{array}{c}\text { Area } \\
\text { no. }\end{array}$ & $\begin{array}{l}\text { Geographic } \\
\text { characteristic }\end{array}$ & Latitude & Longitude & Time \\
\hline 1 & Coastal station Barentsburg (Spitsbergen archipelago) & $78^{\circ} \mathrm{N}$ & $14^{\circ} \mathrm{E}$ & 21 Aug-7 Sep \\
2 & Northeastern margin of Kara Sea & $82^{\circ} \mathrm{N}$ & $98^{\circ} \mathrm{E}$ & $14 \mathrm{Sep}$ \\
3 & Coastal station Polyarka (Tiksi) - coast of Laptev Sea & $72^{\circ} \mathrm{N}$ & $129^{\circ} \mathrm{E}$ & 26 Aug-21 Sep \\
4 & Northeastern margin of Laptev Sea & $80^{\circ} \mathrm{N}$ & $150^{\circ} \mathrm{E}$ & $2 \mathrm{Sep}$ \\
5 & De Long Strait - Chukchi Sea & $69^{\circ} \mathrm{N}$ & $179^{\circ} \mathrm{W}$ & $13 \mathrm{Aug}$ \\
6 & Bering Sea (along coasts of Russia) & $60^{\circ} \mathrm{N}$ & $170^{\circ} \mathrm{E}$ & 4 Sep, 26-28 Sep \\
7 & Near the Pacific coast of Kamchatka & $52^{\circ} \mathrm{N}$ & $159^{\circ} \mathrm{E}$ & 31 Jul, 1-3 Sep \\
8 & Coastal station Vladivostok - coast of Japan Sea & $43^{\circ} \mathrm{N}$ & $132^{\circ} \mathrm{E}$ & 27 Jul-6 Sep \\
\hline
\end{tabular}

Table 3. Average characteristics of AOD and water vapor content in Arctic and Far East seas (the geographic positions of regions 1-8 are presented in Fig. 1 and in Table 2).

\begin{tabular}{|c|c|c|c|c|c|c|c|c|c|}
\hline \multirow[t]{2}{*}{ Characteristics } & \multicolumn{6}{|c|}{ Arctic regions } & \multicolumn{3}{|c|}{ Far East seas } \\
\hline & 1 & 2 & 3 & 4 & 5 & $<2-5>$ & 6 & 7 & 8 \\
\hline$\tau_{037}^{\mathrm{a}}$ & 0.078 & 0.041 & 0.056 & 0.031 & 0.044 & 0.043 & 0.043 & 0.096 & 0.242 \\
\hline$\tau_{0.5}^{\mathrm{a}}$ & 0.053 & 0.029 & 0.038 & 0.026 & 0.028 & 0.030 & 0.033 & 0.058 & 0.186 \\
\hline$\tau_{0.87}^{\mathrm{a}}$ & 0.030 & 0.016 & 0.015 & 0.019 & 0.014 & 0.016 & 0.023 & 0.034 & 0.101 \\
\hline$\tau_{2.14}^{\mathrm{a}}$ & 0.023 & 0.013 & - & 0.014 & 0.009 & 0.012 & 0.016 & 0.022 & 0.044 \\
\hline$\alpha^{2.14}$ & 1.06 & 1.17 & 1.72 & 0.52 & 1.26 & - & 0.67 & 0.85 & 1.04 \\
\hline$\beta$ & 0.026 & 0.013 & 0.011 & 0.018 & 0.012 & - & 0.021 & 0.031 & 0.089 \\
\hline$\tau_{05}^{\mathrm{f}}$ & 0.030 & 0.020 & 0.033 & 0.012 & 0.020 & 0.021 & 0.018 & 0.037 & 0.142 \\
\hline$\tau^{\mathrm{c}^{\mathrm{S}}}$ & 0.023 & 0.011 & 0.006 & 0.012 & 0.008 & 0.009 & 0.015 & 0.022 & 0.044 \\
\hline$W$ & 1.11 & 0.74 & 0.92 & 0.87 & 0.61 & 0.79 & 0.80 & 1.03 & 2.83 \\
\hline
\end{tabular}

ble wavelength range. These atmospheric turbidities seem to be due to aerosol outflows from the direction of Europe and due to the effect of local sources located at Spitsbergen archipelago. Close average AOD values $\left(\tau_{0.5}^{\mathrm{a}}=0.046\right)$ have been reported in other research studies (Herber et al., 2002; Tomasi et al., 2012) for another station on Spitsbergen, namely, Ny-Ålesund, according to observations in the summer-fall periods of 1991-2010.

The AOD characteristics in other Arctic regions, extending from Kara Sea to Chukchi Sea, differ insignificantly and have small values, a factor of 1.7-2.5 smaller than in the European sector of the Arctic (Spitsbergen). For instance, the average AOD values in the regions 2-5 were in the range of $0.026-0.038$ in the wavelength region of $0.5 \mu \mathrm{m}$. In the shortwave part of the spectrum, slightly larger AOD values were observed on the coast of the Laptev Sea (Polyarka), seemingly due to the effect of finely dispersed continental aerosol, like in Barentsburg. We also note that the characteristics of atmospheric depth in the Asian sector of the Arctic and in the subpolar Bering Sea (region 6) are practically the same.

The average AOD values in the Arctic zone (even including Spitsbergen) are approximately a factor of 5 smaller than in background mid-latitude regions: for instance, AOD $(0.5 \mu \mathrm{m})$ is 0.15 and, in particular, $\tau^{\mathrm{c}}=0.04$ and $\tau^{\mathrm{f}}=0.11$ in Tomsk in August-September (Andreev et al., 2012). The small AOD values in the studied regions were because during summer 2013 in the boreal part of Eurasia there were no severe forest fires, which affect the Arctic atmosphere appreciably (Stohl et al., 2006; Eck et al., 2009). These events in the Eurasian part of Russia were last observed in 2010 and 2012 (Chubarova et al., 2012; Sakerin et al., 2014).

Results of AOD measurements onboard RV Professor Khljustin in Far East seas exhibited much stronger variations (Fig. 2b). In the spatial distribution, there is a well apparent latitudinal dependence, with AOD and water vapor content increasing southward. All characteristics in the Bering Sea were the same as in the Arctic, they were a factor of 1.5-2 larger near the southern coasts of Kamchatka, and the difference reached a factor of 4-6 in the region of Vladivostok.

Comparison of finely and coarsely dispersed components of AOD showed that their minimal values $\tau^{\mathrm{f}} \approx 0.02$ and $\tau^{\mathrm{c}}=0.01-0.015$ are characteristic of the Siberian Arctic and the subarctic Bering Sea. The $\tau^{\mathrm{c}}$ value increases by about a factor of 2 , and the $\tau^{\mathrm{c}}$ increases by about a factor of 1.5-2 in the regions of Spitsbergen and southern coasts of Kamchatka; and their largest values are recorded in the region of Vladivostok. Given the general latitudinal decrease of two components of AOD from the Arctic to the Japan Sea, the finely dispersed component varies more appreciably (by a factor of 7). 

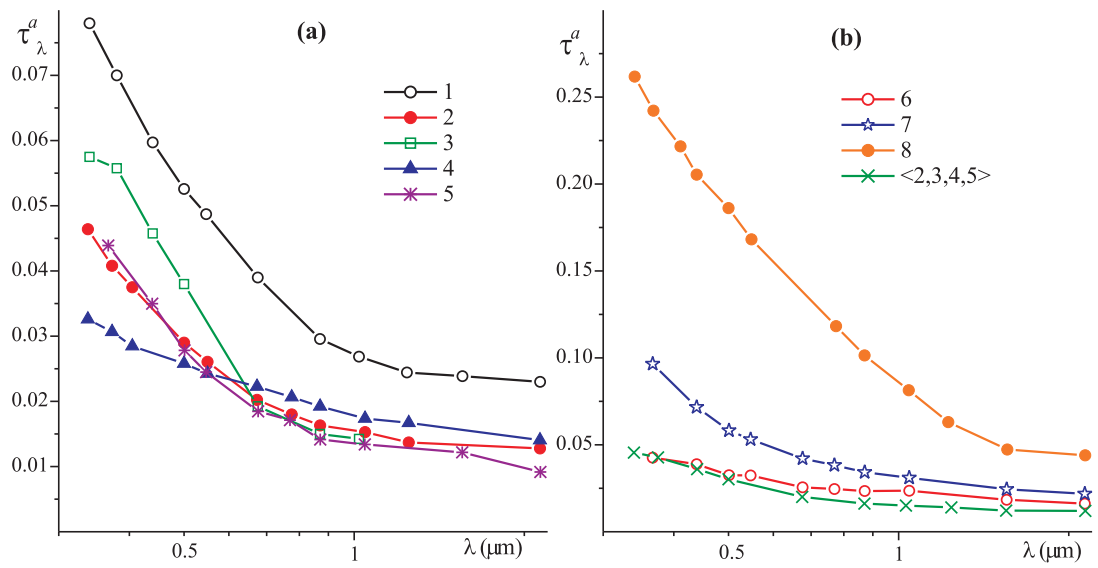

Figure 2. Average spectral dependences of AOD in the regions of (a) the Arctic and (b) Far East seas (symbols $<2,3,4,5>$ indicate the average AOD values for the Arctic regions 2-5).

\subsection{Variations in the atmospheric boundary layer height}

Recent studies by different authors (Kay et al., 2011; Deser et al., 2010; Boé et al., 2009) shown that the processes flowing in the lower atmosphere are key to understanding and modeling the climate changes in Arctic. The climate models in northern regions are often much worse, because parameterizations of atmospheric boundary layer are largely based on observations at more southern latitudes. Studies of the boundary layer height in the Arctic atmosphere will make it possible to improve our understanding and to estimate the scale of the processes of momentum, energy, and water vapor exchange between the underlying surface and the free troposphere.

\subsubsection{Experimental data and method of boundary layer height determination}

Atmospheric aerosol was used as a tracer of the boundary layer (BL). The BL height was determined by gradient (threshold) method according to measurements of the profiles of total depolarization of laser radiation:

$\delta(h)=\frac{P_{\perp}(h)}{P_{\|}(h)}=\frac{\beta_{\perp}^{\pi}(h)}{\beta_{\|}^{\pi}(h)}$.

Here, $P_{\perp}(h)$ and $P_{\|}(h)$ are the cross- and parallel-polarized components of backscattered signal, $\beta_{\perp}^{\pi}(h)$ and $\beta_{\|}^{\pi}(h)$ are the total (aerosol + molecular) backscattering coefficients of cross- and parallel-polarized radiation, respectively, and $\delta(h)$ is the coefficient of total depolarization of laser radiation.

The boundary layer height was assumed to be the height within the first $3000 \mathrm{~m}$, for which the first derivative $\mathrm{d} \delta(h) / \mathrm{d} h$ had the global minimum. This method was successfully applied in our early works (Bukin et al., 2013; Pavlov et al., 2013; Shmirko et al., 2012). It is based on two statements: (1) concentration of aerosol particles sharply jumps at the BL boundary; and (2) the depolarization degree of the aerosol atmosphere is larger than the depolarization degree of the purely molecular atmosphere.

Ship-based measurements of the marine BL height, carried out during the cruise, were compared against measurements with Cloud-Aerosol Lidar with Orthogonal Polarization (CALIOP) satellite lidar. The general characterization of the satellite measurement system, as well as the description of the products obtained, is presented at http://www.nasa. gov/calipso and in Powell et al., 2013. In this case, the BL height was identified by using a modification of the method (Balin et al., 2003), based on the representation of the BL as the ground-adjacent air layer, the properties of which, due to intense turbulent mixing, are determined mainly by thermal and dynamical effects of the underlying surface.

The BL height is determined by calculating the matrix of interlevel correlation (3) of time series of attenuated ratio $P^{\prime}(z, t)$ (typed total_attenuated_backscatter_532 L1B CALIPSO (Cloud-Aersol Lidar and Infrared Pathfinder Satellite Observations) data) of scattering at the wavelength of $532 \mathrm{~nm}$ for different heights in a specified time window:

$$
\begin{aligned}
& \eta_{i, j}=\frac{\sum_{k=1}^{M}\left[\left(P_{i, k}^{\prime}-\overline{P_{i}^{\prime}}\right)\left(P_{j, k}^{\prime}-\overline{P_{j}^{\prime}}\right)\right]}{\sqrt{\sum_{k=1}^{M}\left(P_{i, k}^{\prime}-\overline{P_{i}^{\prime}}\right)^{2} \cdot \sum_{k=1}^{M}\left(P_{j, k}^{\prime}-\overline{P_{j}^{\prime}}\right)^{2}}} \\
& \overline{P_{i(j)}^{\prime}}=\frac{1}{M} \sum_{k=1}^{M} P_{i(j), k}^{\prime},
\end{aligned}
$$

where $P_{i, k}^{\prime}=P^{\prime}\left(z_{i}, t_{k}\right) \quad$ and $P_{j, k}^{\prime}=P^{\prime}\left(z_{j}, t_{k}\right), \quad \forall i<j \in$ $[1 \ldots N], k \in[1 \ldots M]$ are discrete representations of $P^{\prime}(z, t)$, $N$ - number of altitude bins, $M$ - number of temporal (or what is the same, spatial) bins. The matrix of interlevel correlation was calculated by considering only a fragment of the signal, corresponding to the height interval of $100-4000 \mathrm{~m}$ $(N=130)$. 
The higher the position of the scattering layer, the weaker its interrelation with underlying layers is, which immediately affects the correlation coefficient. Therefore, with the availability of the vertical profile of the coefficient of interlevel correlation, and after determining a certain threshold value of this coefficient, the vertical extents of BL can be found. The main feature of the method is its low sensitivity to random signal fluctuations; it works even when gradient methods fail. Despite these advantages, there is nonetheless the uncertainty regarding the choice of the critical value of the correlation coefficient. In the given case, the threshold correlation coefficient of 0.55 was determined by comparing the BL heights, measured by ship-based lidar, with the vertical profile of the coefficient of interlevel correlation. The algorithm for data processing consisted of the following stages:

1. selection of data from spatiotemporal window $(M=$ 120 points, $40 \mathrm{~km}$ ) for regions, located over the sea surface;

2. cloud filtering (the data of measurements were removed from the sample if the profiles of attenuated backscattering contained quite intense peaks in this height interval);

3. calculation of BL height (including calculation of the matrix of interlevel correlation, the average profile of interlevel correlation, and height, satisfying the choice criterion);

4. shift of the window by one profile $(\sim 333 \mathrm{~m}$ in the plane of the Earth);

5. return to point 1 .

The method described in several other works (Hennemuth and Lammert, 2006; Vogelezang and Holtslag, 1996; Menut et al., 1999; Troen and Mahrt, 1986) was used to retrieve the boundary layer height according to reanalysis data.

\subsubsection{Spatiotemporal variations in the boundary layer height}

Figure 3 illustrates the temporal and latitudinal variations in the BL height in the period of expedition of RV Professor Khljustin. The BL height $\left(H_{\mathrm{BL}}\right)$ varied in the wide range from 200 to $1200 \mathrm{~m}$. The average height $H_{\mathrm{BL}}$ over the entire cruise was $520 \pm 195 \mathrm{~m}$, and the most probable value was $612 \mathrm{~m}$. The obtained quantitative characteristics correspond to literature data, suggesting that $H_{\mathrm{BL}}$ is on average $420 \mathrm{~m}$ (Wang and Wang, 2004), $800 \mathrm{~m}$ (Bradley and Keimig, 1993), and $934 \pm 300 \mathrm{~m}$ (Nilsson, 1996). The maximum value $H_{\mathrm{BL}}=1200 \mathrm{~m}$ was observed near the port of Pevek throughout 21 August 2013.

As for the latitudinal distribution of $H_{\mathrm{BL}}$ (Fig. 3b), it exhibits periodic regularity. Initially the BL height decreases with latitude up to $55^{\circ} \mathrm{N}$; and then the trend becomes opposite to this. The $\mathrm{BL}$ heights were high in the region of the Bering Strait, and then $H_{\mathrm{BL}}$ decreased somewhat. Similar variations in the BL height were found in the Southern Hemisphere within the framework of the Global Backscatter Experiment (GLOBE) (Menzies and Tratt, 1997). The BL subsidence rate is $25 \mathrm{~m} \mathrm{degree}^{-1}$ on the first $\left(43.1-55^{\circ} \mathrm{N}\right)$ and second $\left(55-65^{\circ} \mathrm{N}\right)$ segments, and it becomes equal to $50 \mathrm{~m}$ degree $^{-1}$ on the third segment $\left(65-70^{\circ} \mathrm{N}\right)$.

The $H_{\mathrm{BL}}$ value behaves analogously in CALIPSO satellite data, with the only difference being that the dispersion of the data is not that high. For the areas considered here (regions of the northeastern part of the Pacific Ocean and the eastern Arctic), the boundary layer height, retrieved according to satellite data, and its latitudinal dependence are in good correspondence with ship-based measurements: the correlation coefficient is 0.5 at 0.95 significance level, and the critical value of the correlation coefficient for this sample is 0.24 . The CALIPSO data also display the characteristic minimum of $H_{\mathrm{BL}}$ in the region of $55^{\circ} \mathrm{N}$, with its subsequent growth in the northern direction.

The latitudinal decrease of the BL height has been confirmed in other works (Zilitinkevich and Esau, 2009); however, further $H_{\mathrm{BL}}$ growth (at latitudes poleward of $55^{\circ} \mathrm{N}$ ) does not fit into the classical concept of the latitudinal BL variations and seems to be due to the specific character of the region (terrain topology, wind and temperature regimes, etc.). Despite the coincidence of $H_{\mathrm{BL}}$, obtained by two methods, the probability remains for its overestimation at northern latitudes by virtue of specific features of the methods used. The method for determining $H_{\mathrm{BL}}$ from satellite data through the critical value of the coefficient of interlevel correlation is implicitly related to $H_{\mathrm{BL}}$, determined according to shipbased lidar measurements.

The problem was resolved by additionally calculating the BL heights according to reanalysis data (the profiles of temperature and wind speed) (Hennemuth and Lammert, 2006; Vogelezang and Holstang, 1996; Menut et al., 1999; Troen and Mahrt, 1986). Since this method is based on modelderived meteorological parameters, it is less subject to the effect of local aerosol sources, land, and low clouds. The main sources of data for reanalysis are the stations of upperair measurements. These stations are sparse in the study region and are completely absent over sea. Therefore, the results of the BL height calculations should be interpreted as averages for this period. From Fig. $3 b$ it can be evident (see the black line with triangles) that the latitudinal distribution of the BL height somewhat differs from analogous data of satellite and ship-based measurements: the $H_{\mathrm{BL}}$ variations are not strongly pronounced, and their amplitude does not exceed $200 \mathrm{~m}$.

Reanalysis data suggest that the BL height decreases from 500 to $400 \mathrm{~m}$ as latitude changes from 40 to $53^{\circ} \mathrm{N}$, and further northward it remains at practically the same level. The maximum differences in $H_{\mathrm{BL}}$, obtained by different methods, are observed in southern $\left(\sim 45^{\circ} \mathrm{N}\right)$ and northern $\left(\sim 67^{\circ} \mathrm{N}\right)$ parts of the region analyzed. In the southern part, the de- 
(a)

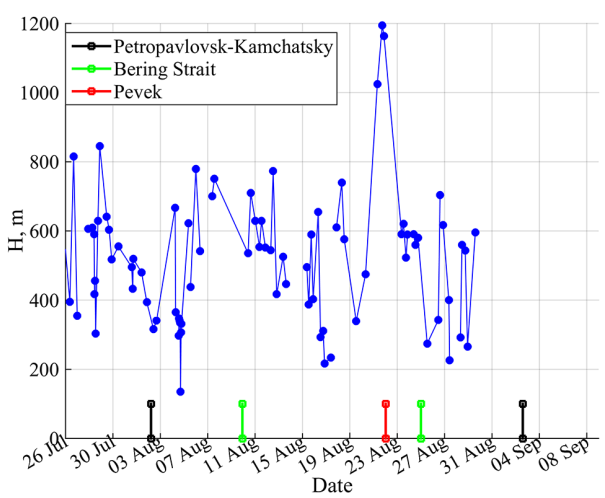

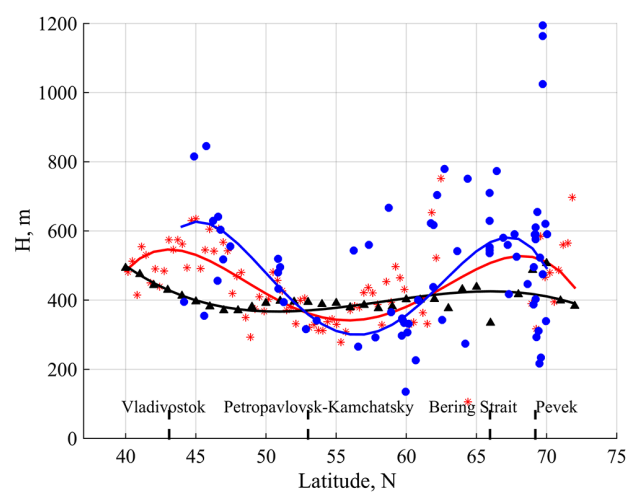

Figure 3. (a) The temporal behavior and (b) the latitudinal dependence of height $H_{\mathrm{BL}}$, calculated according to data of ship-based measurements (blue circles), CALIPSO satellite (red asterisks), and ECMWF reanalysis (black line with rectangles). Solid lines show polynomial fits of the latitudinal dependence of $H_{\mathrm{BL}}$.

creased $H_{\mathrm{BL}}$ values, calculated according to reanalysis data, can be ascribed to the specific character of ECMWF data. At Arctic latitudes, higher $H_{\mathrm{BL}}$ values, calculated according to data of CALIPSO and ship-based lidar, seem to be due to increased influence of land (Chukchi Peninsula).

To understand the reasons for these spatial BL variations, we analyzed the back trajectories of motion of air masses (https://ready.arl.noaa.gov/HYSPLIT.php), calculated for every hour of expedition measurements. Analysis was made for three segments of the route: (1) the region of small $H_{\mathrm{BL}}$ values at the $55^{\circ} \mathrm{N}$ latitude; (2) the region of high $H_{\mathrm{BL}}$ on the territory of the Bering Strait; and (3) the region of extremely high $H_{\mathrm{BL}}$ values in the area of Pevek. The back trajectory analysis gave the following results (Fig. 4).

The boundary layer height was relatively small $(\sim 380-$ $400 \mathrm{~m}$ ) if the wind blew from the direction of the open ocean (Fig. 4a), or if the air masses had passed over the water surface during most of the preceding day (Fig. 4b). Otherwise, if the trajectories of air motion passed over the land (Fig. 4c,d), a higher level of $H_{\mathrm{BL}}$ values $(\sim 800 \mathrm{~m})$ was observed. The largest BL height $(\sim 1200 \mathrm{~m})$ was recorded near the port of Pevek, when air propagated over land from the direction of the city (Fig. 4d). The local temperature field is, on average, $3-4^{\circ}$ higher in the city; therefore, higher $H_{\mathrm{BL}}$ values should be expected on the lee side.

\section{Aerosol and black carbon contents in the near-ground atmospheric layer}

\subsection{Specific features of spatial aerosol variations in Arctic seas}

The routes of expedition cruises of RVs Akademik Fedorov and Professor Khljustin encompass quite a large (no less than $5000 \mathrm{~km}$ ) territory in the Arctic zone, predetermining the need to identify separate regions (and data sets) for interpreting the aerosol microphysical characteristics.

Preliminary analysis of measurements onboard RV Akademik Fedorov showed that the latitudinal and meridional dependences in $N_{\mathrm{A}}, M_{\mathrm{A}}$, and $M_{\mathrm{BC}}$ concentrations were not explicitly present, but separate parameters somewhat decreased in a northeastern direction. That is, the effect of continental aerosol sources weakened with distance from Scandinavian coasts. Based on the findings above, in the Arctic zone we singled out the following four regions (their geographic positions are indicated in Fig. 1):

K. area of the Barents Sea near coasts of the Kola Peninsula;

B. the Barents Sea - western sector of the Arctic;

A. the Arctic Ocean - northern margins of the Kara and Laptev seas;

F. the East Siberian and Chukchi seas - Far East sector of the Arctic.

The statistical characteristics of $N_{\mathrm{A}}, M_{\mathrm{A}}$, and $M_{\mathrm{BC}}$ for these regions, calculated according to diurnally average values, are presented in Table 4. As expected, the highest average concentrations of aerosol and black carbon and the widest variability ranges were observed near Kola Peninsula (region K). The average values of all characteristics decreased with distance from Scandinavia, but differently with respect to separate parameters. The largest changes occurred in absorber content. The average $M_{\mathrm{BC}}$ value in region $\mathrm{B}$ decreased by a factor of 2.5 , and it decreased by another factor of 2.5 in region A (on the whole, $M_{\mathrm{BC}}$ decreased by the factor of 7 as compared to the region $\mathrm{K}$ ).

The number and mass concentrations of aerosol decreased by 15 and $28 \%$, respectively, only in transport from the Kola Peninsula to the high-latitude part of the Barents Sea. The 

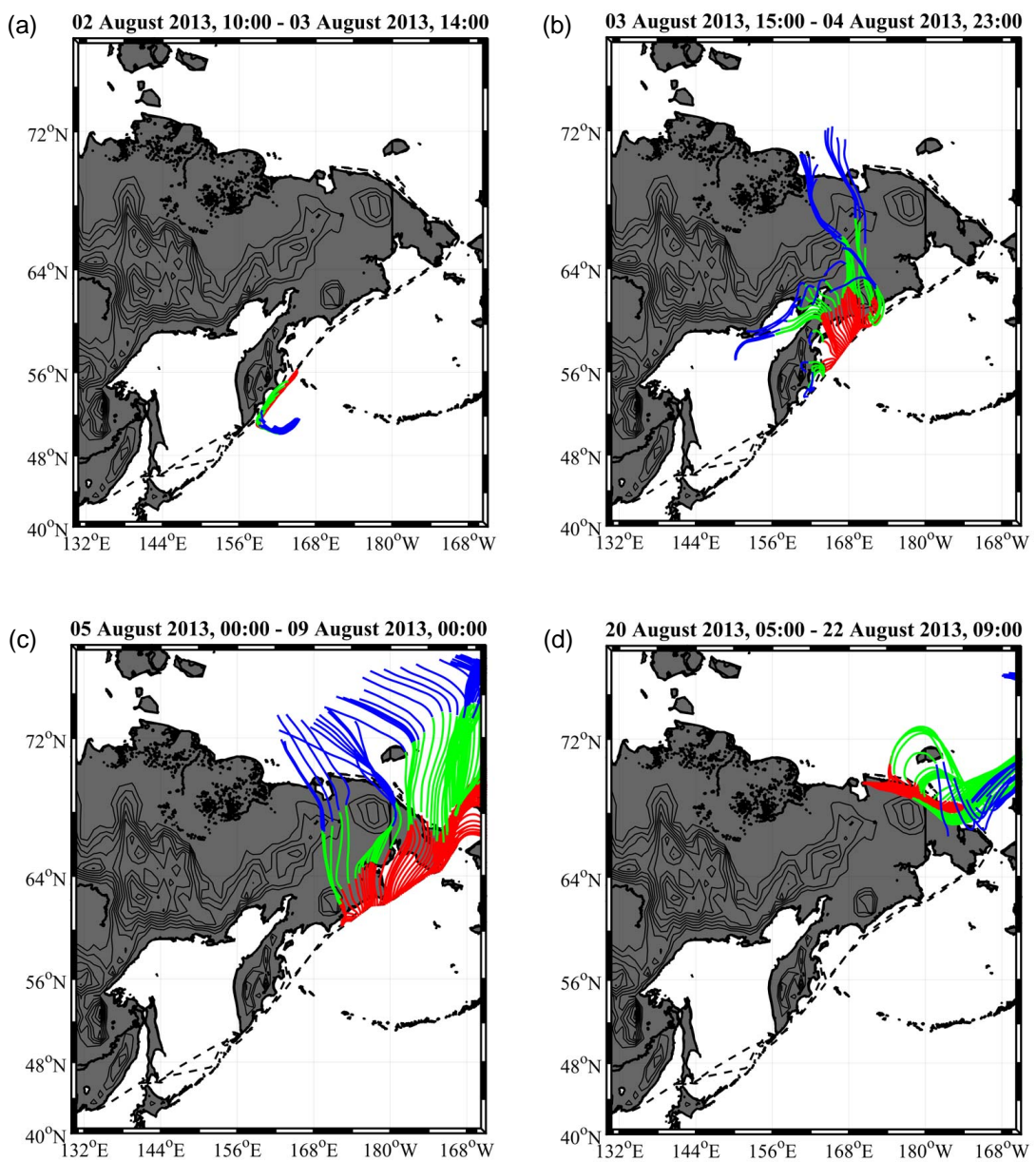

Figure 4. Trajectories of air mass motion: red is for the third day of motion of air masses, green is for the second day, and blue is for the first day.

difference in $N_{\mathrm{A}}$ and $M_{\mathrm{A}}$ concentrations between Arctic regions $\mathrm{B}$ and $\mathrm{A}$ was found to be insignificant, much less than the standard deviation.

Table 4 also presents the statistical characteristics of aerosol and black carbon concentrations, measured onboard RV Professor Khljustin in Far East sector of Arctic (region F). We note the following specific features of aerosol parameters in this region. The average aerosol number concentration in region $\mathrm{F}$ turned out to be the lowest (by more than a factor of 2) among other Arctic regions, while the mass concentration differed insignificantly.

The seeming mismatch between $N_{\mathrm{A}}$ and $M_{\mathrm{A}}$ values in the Far East sector (relative to other regions) is explained by a relatively large content of coarsely dispersed aerosol, which was caused by hydrometeorological conditions. The period of changes in the Chukchi and East Siberian seas was characterized by relatively frequent fogs and stronger sea surface roughness. As is well-known (Reist, 1993; Rasool, 1973), both these factors favor the increase in the content of coarsely dispersed aerosol, which makes a major specific contribution to aerosol mass concentration.
From comparison of the average particle distributions over volumes $\mathrm{d} V / \mathrm{d} r$ (Fig. 5), it can be seen that measurements in region $\mathrm{F}$ were indeed characterized by elevated content of larger particles in the size range $r>0.7 \mu \mathrm{m}$ and by decreased content of small particles $(r<0.3 \mu \mathrm{m})$. Relatively large aerosol concentrations in the entire particle size range were recorded on the segment of the route near the Kola Peninsula. Evidently, this disperse composition was explained by the effect of aerosol outflows from the continent, as well as by the generation of maritime aerosol under the conditions of developed sea roughness.

The smallest-valued and practically identical distributions $\mathrm{d} V / \mathrm{d} r$ were observed in high-latitude Arctic regions $\mathrm{B}$ and A, primarily because of their remoteness from continental aerosol sources, low temperatures, and weak generation of maritime aerosol on largely ice- and snow-covered territories.

Comparison of distributions $\mathrm{d} V / \mathrm{d} r$, obtained during Arctic expeditions in 2013, against the data of preceding studies in the White and Kara seas, and in Tiksi (June 2010) and Barentsburg (July 2011) (Pol'kin et al., 2011a; Sakerin et al., 
Table 4. Statistical characteristics of near-water aerosol in Arctic seas: the numerator indicates mean and standard deviation ( \pm SD); and the denominator indicates the minimum ( $\min )$ and maximum $(\max )$ values, and the number of days of measurements $(n)$.

\begin{tabular}{|c|c|c|c|}
\hline Region and period of measurements & $\begin{array}{l}N_{\mathrm{A}}, \mathrm{cm}^{-3} \\
\frac{\operatorname{mean} \pm \mathrm{SD}}{\min -\max (n)}\end{array}$ & $\begin{array}{l}M_{\mathrm{A}}, \mathrm{ng} \mathrm{m}^{-3} \\
\frac{\operatorname{mean} \pm \mathrm{SD}}{\min -\max (n)}\end{array}$ & $\begin{array}{l}M_{\mathrm{BC}}, \mathrm{ng} \mathrm{m}^{-3} \\
\frac{\operatorname{mean} \pm \mathrm{SD}}{\min -\max (n)}\end{array}$ \\
\hline $\begin{array}{l}\text { K. Barents Sea near Kola Peninsula coasts (68- } \\
71^{\circ} \mathrm{N}, 18-21 \text { Aug, RV Akademik Fedorov) }\end{array}$ & $\frac{6.52 \pm 1.77}{5.39-8.56(3)}$ & $\frac{1290 \pm 70}{1260-1360(3)}$ & $\frac{140 \pm 100}{80-250(3)}$ \\
\hline $\begin{array}{l}\text { B. Barents Sea }\left(71-81^{\circ} \mathrm{N}, 21-23 \text { Aug and 19- }\right. \\
21 \text { Sep, RV Akademik Fedorov) }\end{array}$ & $\frac{5.55 \pm 1.08}{4.83-7.44(5)}$ & $\frac{930 \pm 230}{710-1250(5)}$ & $\frac{60 \pm 20}{30-80(6)}$ \\
\hline $\begin{array}{l}\text { A. Arctic Ocean }\left(77-84^{\circ} \mathrm{N}, 24 \text { Aug-18 Sep, }\right. \\
\text { RV Akademik Fedorov) }\end{array}$ & $\frac{5.76 \pm 2.92}{2.02-11.9(25)}$ & $\frac{880 \pm 540}{230-2610(25)}$ & $\frac{20 \pm 10}{10-50(26)}$ \\
\hline $\begin{array}{l}\text { F. Chukchi and East Siberian seas }\left(69-71^{\circ} \mathrm{N} \text {, }\right. \\
\text { 9-24 Aug, RV Professor Khljustin) }\end{array}$ & $\frac{2.5 \pm 1.5}{0.260-4.30(14)}$ & $\frac{830 \pm 680}{670-2320(14)}$ & $\frac{50 \pm 20}{20-90(15)}$ \\
\hline
\end{tabular}

2012) has led to the following conclusions (see Fig. 5). The average $\mathrm{d} V / \mathrm{d} r$ in high-latitude regions decrease in a northeastern direction (in accordance with the influence degree of the sources of continental aerosol), and the range of their difference reaches 2 orders of magnitude. The maximum values of $\mathrm{d} V / \mathrm{d} r$ in the entire size range are characteristic of subpolar and, virtually, internal White Sea. Intermediate values of $\mathrm{d} V / \mathrm{d} r$ were observed in Kara Sea and on Spitsbergen archipelago (Barentsburg), and the lowest level was observed over the Arctic Ocean and in Tiksi. Low volume concentration of submicron particles in the region of Tiksi (June 2010) can be explained by relatively low air temperature under the conditions when a major part of coastal zone of sea and tundra were still covered by ice and snow (Sakerin et al., 2012).

On the whole, the average values of the concentrations $N_{\mathrm{A}}, M_{\mathrm{A}}$, and $M_{\mathrm{BC}}$, obtained in the regions $\mathrm{K}, \mathrm{B}, \mathrm{A}$, and $\mathrm{F}$, agree with studies by other authors in the Russian sector of Arctic. For instance, the average number concentrations of $4-8 \mathrm{~cm}^{-3}$, i.e., close to our data, were obtained in groundbased measurements on Franz Josef Land (Ziegler Island, spring 1994; Smirnov et al., 1998). However, at the same time, the aerosol mass concentration turned out to be much higher: $(25-50) \times 10^{3} \mathrm{ng} \mathrm{m}^{-3}$. The authors explained the elevated mass concentrations by the presence of soil-derived particles in the region of measurements.

Ship-based measurements of black carbon mass concentration during fall of 1998 in the Barents Sea (Kopeikin et al., 2010) showed that the average values of $M_{\mathrm{BC}}$ varied from $160 \mathrm{ng} \mathrm{m}^{-3}$ during northerly and northeasterly winds to $980 \mathrm{ng} \mathrm{m}^{-3}$ when wind blows from western Siberia. Most probably, relatively high $M_{\mathrm{BC}}$ values were due to severe fires in the boreal zone of western Siberia. Based on aircraft measurements in April 1992 over the East Siberian Sea (Hansen et al., 1997), the average values of $M_{\mathrm{BC}}$ in the nearground layer (height of $\sim 100 \mathrm{~m}$ ) were about $150 \mathrm{ng} \mathrm{m}^{-3}$. Lower black carbon concentrations $\left(8-16 \mathrm{ng} \mathrm{m}^{-3}\right)$ for the summer period have been reported in several works (Sharma

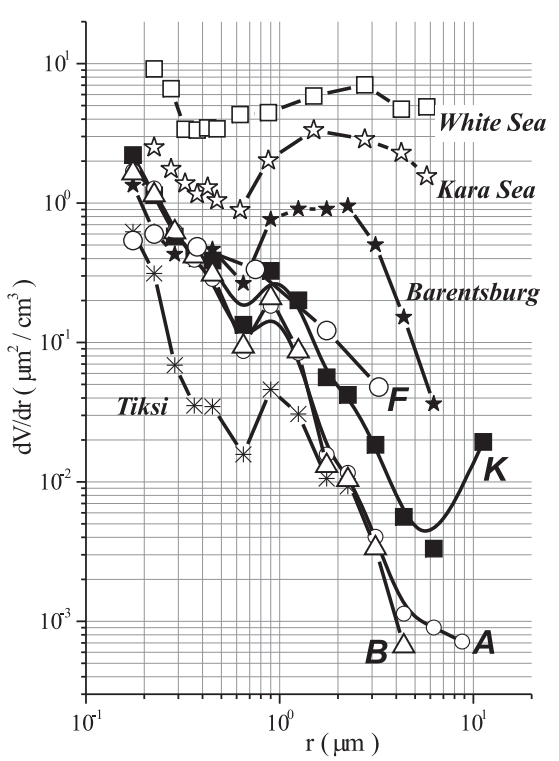

Figure 5. The average volume distributions of aerosol particles $\mathrm{d} V / \mathrm{d} r$ in the regions $\mathrm{K}, \mathrm{B}, \mathrm{A}$, and $\mathrm{F}$ as compared to analogous data in the White and Kara seas, in Tiksi, and Barentsburg (Sakerin et al., 2012).

et al., 2004, 2013; Stone et al., 2014; Eleftheriadis et al., 2009) on the basis of multiyear (1989-2005) measurements at three Arctic sites: Alert (Canada), Barrow (Alaska), and Zeppelin (Svalbard). The average black carbon concentrations at these stations are close to our data, obtained over the Arctic Ocean (region A). It can also be noted that the average $M_{\mathrm{BC}}$ values near the Kola Peninsula (region $\mathrm{K}$ ) agree well with multiyear (1964-2010) average black carbon concentrations $\left(127 \mathrm{ng} \mathrm{m}^{-3}\right)$ at the station nearest to the route, at Kevo in the north of Finland (Dutkiewicz et al., 2014), consistent with the fact that black carbon content in region $\mathrm{K}$ is determined by continental sources. 

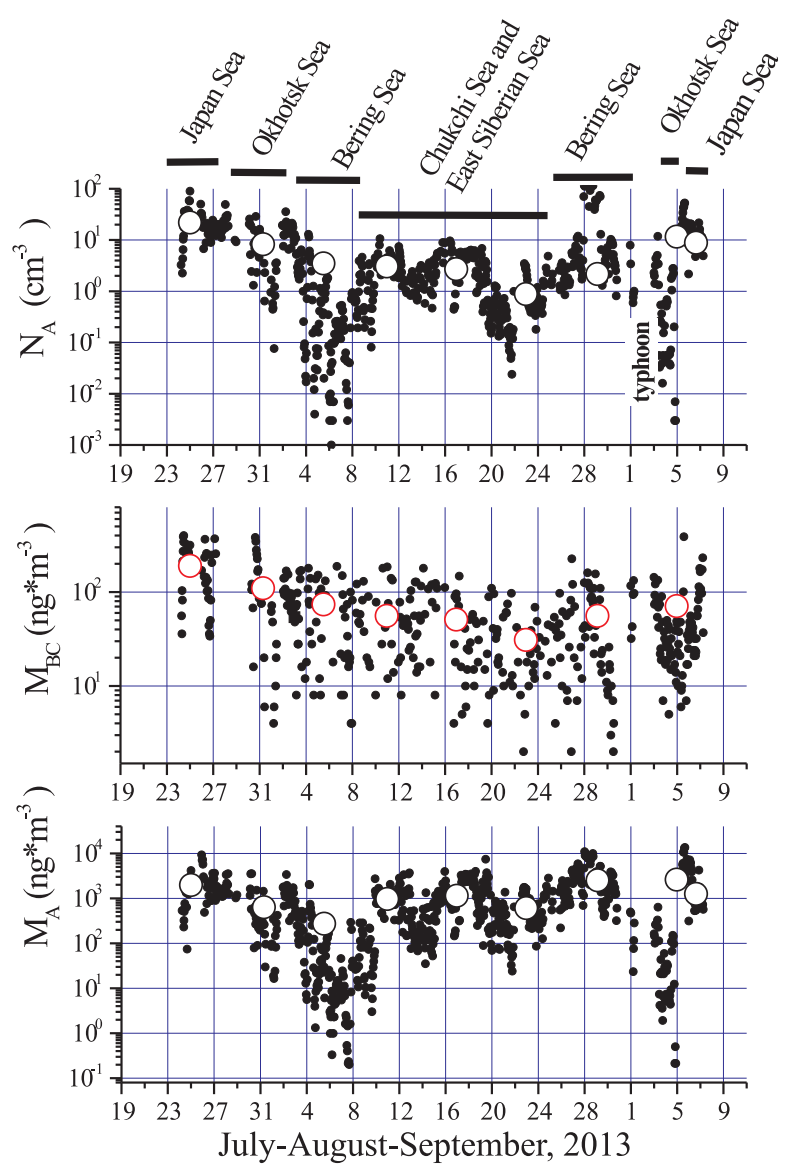

Figure 6. Temporal behavior of the parameters $N_{\mathrm{A}}, M_{\mathrm{A}}$, and $M_{\mathrm{BC}}$ on the route of RV Professor Khljustin (circles indicate the average values of the parameters in water basins of separate seas).

\subsection{Latitudinal dependence of aerosol and black carbon distributions in Far East seas}

The route of RV Professor Khljustin followed predominately in meridional direction from Vladivostok to port of Pevek, through the Japan, Okhotsk, Bering, Chukchi, and East Siberian seas (Fig. 1). The temporal behavior of aerosol and black carbon concentrations for the entire period of expedition is presented in Fig. 6. We should turn attention to strong variations in the parameters $N_{\mathrm{A}}, M_{\mathrm{A}}$, and $M_{\mathrm{BC}}$, which were caused by diurnal and synoptic changes in the hydrometeorological conditions. In all study regions, the variations in each parameter within 1-3 days exceed 1 order of magnitude, and the total variability ranges were from 0.003 to $90.2 \mathrm{~cm}^{-3}$ for $N_{\mathrm{A}}$; from 1 to $13630 \mathrm{ng} \mathrm{m}^{-3}$ for $M_{\mathrm{A}}$; and from 2 to $400 \mathrm{ng} \mathrm{m}^{-3}$ for $M_{\mathrm{BC}}$. Even when the data are averaged over separate sea water basins (shown by circles), the average aerosol characteristics markedly differ between forward and return routes.

In particular, the average values of aerosol number and mass concentrations over the Japan Sea turned out to be

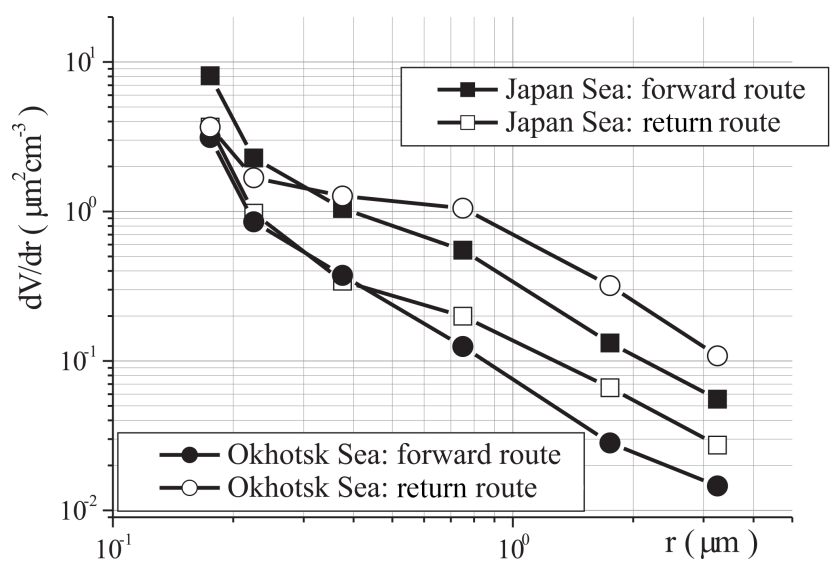

Figure 7. The average volume distributions of aerosol particles over the Japan and Okhotsk seas, obtained on the forward and return routes of RV Professor Khljustin.

about a factor of 2 larger at the beginning of cruise than on the return route. This difference was because of the stronger sea roughness (Beaufort numbers of 3-4) and the corresponding generation of large particles of maritime aerosol. In addition, outflows of submicron aerosol from the direction of continent had a stronger effect at the beginning of cruise. The specific features of the average disperse composition of aerosol on forward and return routes for two seas are illustrated in Fig. 7.

From the figure it can be seen that in the range of large particles, the volume distributions $\mathrm{d} V / \mathrm{d} r$ over the Okhotsk Sea are approximately an order of magnitude larger on the return route than on the forward route, primarily because sea was extremely rough after passage through the typhoon. Because of the substantial predominance of coarsely dispersed particles, the average mass concentration $M_{\mathrm{A}}$ in this case turned out to be the highest $\left(13630 \mathrm{ng} \mathrm{m}^{-3}\right)$ over the entire period of measurements.

Thus, the short periods of measurements in separate water basins on forward and return routes (from 3 to 9 days), given the high variability of the studied parameters, turn out to be insufficient to obtain a reliable information on average characteristics of aerosol in any region. Nonetheless, in the variations of the aerosol parameters we discern a decrease during the first half of the cruise (which followed northward) and an increase in the aerosol and black carbon concentrations on the return.

The aerosol parameters were diurnally averaged to mitigate the effect of short-period variations. Analysis of regression dependences of the diurnally average values of $N_{\mathrm{A}}, M_{\mathrm{A}}$, and $M_{\mathrm{BC}}$ on the geographic latitude $\phi$ (Fig. 8) confirms that these values tend to decrease in the northern direction. The equations of the linear regression of separate parameters are presented in the upper part of the figure, and the correlation coefficients for regression lines are indicated in parentheses. We note that the latitudinal dependences for all aerosol pa- 


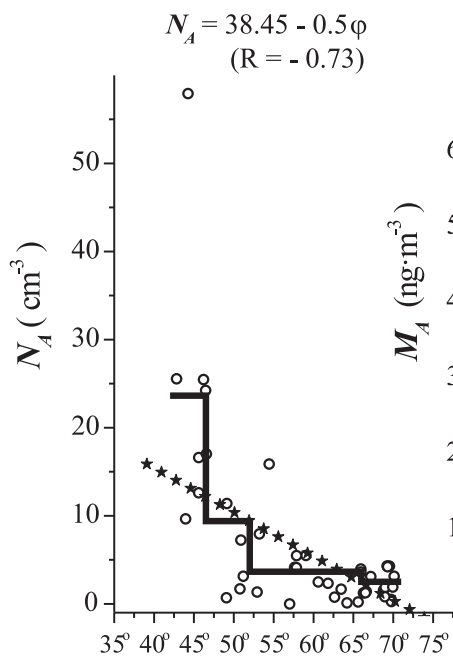

$\varphi$

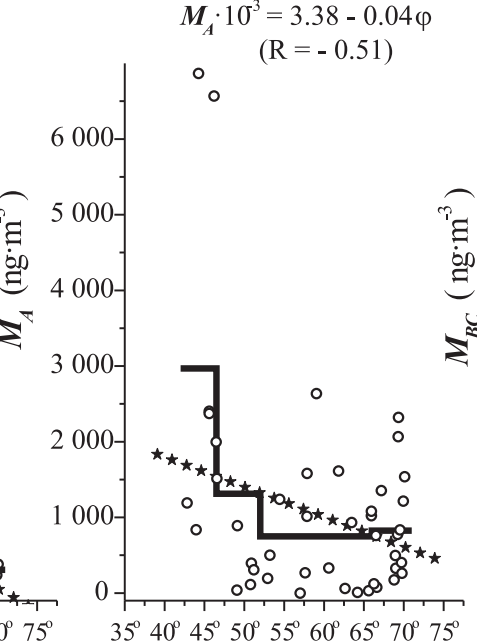

$\varphi$

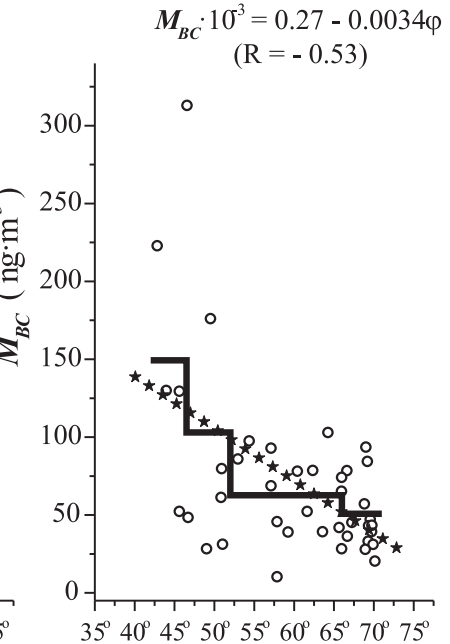

$\varphi$

Figure 8. Latitudinal distribution of parameters $N_{\mathrm{A}}, M_{\mathrm{A}}$, and $M_{\mathrm{BC}}$ in Far East seas: asterisks indicate the linear regression, and thick lines indicate the average values within separate latitude zones.

Table 5. Statistical characteristics of aerosol in Far East seas: the numerator indicates mean and standard deviation ( \pm SD); and the denominator indicates the minimum (min), maximum (max) values, and the number of measurement days $(n)$.

\begin{tabular}{|c|c|c|c|}
\hline Area & $N_{\mathrm{A}}, \mathrm{cm}^{-3}$ & $M_{\mathrm{A}}, \mathrm{ng} \mathrm{m}^{-3}$ & $M_{\mathrm{BC}}, \mathrm{ng} \mathrm{m}^{-3}$ \\
\hline Japan Sea, $42-46.5^{\circ} \mathrm{N}$ & $\frac{23.6 \pm 15.1}{0.56-579(8)}$ & $\frac{2970 \pm 2380}{840-6670(8)}$ & $\frac{150 \pm 100}{50}$ \\
\hline Okhotsk Sea $465-52^{\circ} \mathrm{N}$ & $\begin{array}{l}9.66-57.9(8) \\
9.4 \pm 10.2\end{array}$ & $\begin{array}{c}840-6870(8) \\
1310 \pm 2220\end{array}$ & $\begin{array}{l}50-310(6) \\
100 \pm 100\end{array}$ \\
\hline UKHOLSK Jea, 40.J-JZ IN & $\overline{0.687-25.5(8)}$ & $\overline{40-6570(8)}$ & $\overline{30-310(8)}$ \\
\hline Bering Sea, 52-67 $\mathrm{N}$ & $\frac{3.6 \pm 4.1}{0.117-15.9(18)}$ & $\frac{750 \pm 760}{10-2640(18)}$ & $\frac{60 \pm 30}{10-100(18)}$ \\
\hline Chukchi and East Siberian seas, $67-71^{\circ} \mathrm{N}$ & $\frac{2.5 \pm 1.5}{0.260-4.30(14)}$ & $\frac{830 \pm 680}{670-2320(14)}$ & $\frac{50 \pm 20}{20-100(15)}$ \\
\hline
\end{tabular}

rameters are statistically significant. In this case, the level of statistically significant correlation is 0.3 with 0.95 confidence probability.

To obtain the quantitative data on the spatial distribution of aerosol characteristics, the average values of $N_{\mathrm{A}}, M_{\mathrm{A}}$, and $M_{\mathrm{BC}}$ were additionally calculated within four latitude zones 42-46.5-52-67-71 ${ }^{\circ} \mathrm{N}$, which approximately correspond to separate seas: the Japan, Okhotsk, Bering, Chukchi, and East Siberian seas. The obtained average values of aerosol parameters are presented in Table 5 and shown in Fig. 8 by thick lines. From the figure it can be seen that the latitudinal decrease is more firmly manifested for aerosol number concentration and black carbon mass concentration: $N_{\mathrm{A}}$ decreased from $23.7 \mathrm{~cm}^{-3}$ over the Japan Sea to $2.5 \mathrm{~cm}^{-3}$ over the Chukchi Sea (by about a factor of 9), and $M_{\mathrm{BC}}$ decreased from 149 to $51 \mathrm{ng} \mathrm{m}^{-3}$ (by about a factor of 3 ).

In the variations of aerosol mass concentration $M_{\mathrm{A}}$, there was also first a decrease, followed by a minor growth during transport to higher latitudes. This behavior is explained by the redistribution of contributions of fine and coarse aerosols to $M_{\mathrm{A}}$, primarily due to the specific hydrometeorological conditions during cruise. The large concentration of submi- cron aerosol over the Japan Sea (for a moderate content of large particles) ensured the relatively high average level of $M_{\mathrm{A}}$. In transport to the Okhotsk Sea, and then to the Chukchi and Bering seas, the content of small particles had substantially decreased, so that the value of $M_{\mathrm{A}}$ had been determined only by variations in coarsely dispersed aerosol, generated from the sea surface. Its concentration at high latitudes remained at quite a high level due to wind-driven roughness; therefore, no $M_{\mathrm{A}}$ decrease occurred.

We know nothing about analogous studies by other authors in these regions. Data of our measurements onboard the sailing vessel Nadezhda in the area of the Okhotsk Sea in August 2010 (Polkin et al., 2011b) can only be presented for comparison purposes. The average values of aerosol parameters, obtained in this expedition $\left(N_{\mathrm{A}}=40.6 \mathrm{~cm}^{-3}\right.$; $\left.M_{\mathrm{A}}=8000 \mathrm{ng} \mathrm{m}^{-3} ; \quad M_{\mathrm{BC}}=520 \mathrm{ng} \mathrm{m}^{-3}\right)$, are severalfold larger than the data of measurements onboard RV Professor Khljustin in 2013. The differences in hydrometeorological conditions and routes between the two cruises (regions of measurements) explain these discrepancies. A considerable part of data in August 2010 was obtained near the Kuril Islands chain and the island of Sakhalin, with a larger influ- 
ence of continental sources. In this case, the maximum concentrations reached the following values: $N_{\mathrm{A}}=350 \mathrm{~cm}^{-3}$; $M_{\mathrm{A}}=141000 \mathrm{ng} \mathrm{m}^{-3}$; and $M_{\mathrm{BC}}=19000 \mathrm{ng} \mathrm{m}^{-3}$. In addition, the conditions of measurements were characterized by more frequent fogs and high relative humidity of air. That is, the data of the two expeditions do not contradict each other, but just indicate the strong dependence of aerosol characteristics on the effects of outflows of continental aerosol and meteorological conditions.

\subsection{Effect of meteorological conditions on aerosol number concentration in the RV Professor Khljustin cruise}

As is well known, the concentration of aerosols in the atmosphere is caused not only by the intensity of emissions from different sources, lifetime, and particle transformation, but also by meteorological conditions: wind, humidity, rainfall, characteristics of air flows (trajectories, transport height), etc. These factors differently influence the content of aerosol particles with diverse sizes. Therefore, below we will consider not only the total number concentration $N_{\mathrm{A}}$, but also the concentrations of submicron $N_{\mathrm{f}}(0.3 \mu \mathrm{m} \leq d \leq 1.0 \mu \mathrm{m})$ and coarsely dispersed $N_{\mathrm{c}}(1.0 \mu \mathrm{m}<d \leq 10 \mu \mathrm{m})$ fractions: $N_{\mathrm{A}}=N_{\mathrm{f}}+N_{\mathrm{c}}$.

Figure 9 shows the temporal behavior of characteristics, measured in the period of expedition: number concentrations of submicron and coarsely dispersed aerosol; volume particle size distributions; relative humidity; and wind speed. Also shown in the figure are characteristics, calculated according to 72-h back trajectories of air mass motion (using data at http://ready.arl.noaa.gov/HYSPLIT.php): the total along-trajectory rainfall amount and the fraction of trajectories passing over land.

The relative air humidity was close to $100 \%$ in the period of expedition; nonetheless, dips, caused by arrival of dryer continental air masses at the region of measurements, can be periodically seen on the plot. The wind speed varied in a wide range, from perfect calm to $20 \mathrm{~m} \mathrm{~s}^{-1}$. The particle number concentration is most dynamical variable among aerosol microphysical parameters (Figs. 6a and 9a, b). The range of $N_{\mathrm{A}}$ variations over the entire period of expedition was more than 4 orders of magnitude. The mass concentrations $M_{\mathrm{A}}$ and $M_{\mathrm{BC}}$ varied less strongly (Fig. 6b, c), approximately in the range of 3 and 2 orders of magnitude respectively.

The specific features of variations in the concentrations of separate fractions $N_{\mathrm{f}}$ and $N_{\mathrm{c}}$ in different regions will be analyzed below; and first we will estimate the effect of the meteorological parameters on the total concentration $N_{\mathrm{A}}$ over the entire period of measurements. For this, we considered a regression model with the use of available data on wind speed (WS), water temperature, air temperature $(T)$, rainfall amount $(\mathrm{RF})$, and fraction of trajectories passing over land. To construct the regression equation, we used an iteration algorithm which sought the approximation coefficients and discrepancy at each step by least squares method. Data (bursts) were excluded from the initial sample if the discrepancy exceeded three standard deviations (SD). The calculations continued until no bursts remained. As a result, we obtained a model which depended on just three parameters:

$N_{\mathrm{A}}=0.645+0.209 \cdot \mathrm{WS}-0.104 \cdot T+0.018 \cdot \mathrm{RF}$.

Classical equation that relates $N_{\mathrm{A}}$ and wind speed looks like $\log N_{\mathrm{A}}=a \cdot \mathrm{WS}+b$ (Bigg et al., 1995; Andreas, 1998). In our case of multiple regression, we used a linear dependence of particle concentration on wind speed because this relationship gives better least squares approximation. The first term of (Eq. 5) corresponds to background aerosol concentration under calm conditions and at an air temperature of $0{ }^{\circ} \mathrm{C}$. The second term is associated with wind-driven aerosol generation. It is positive, meaning that the greater the wind speed, the larger the aerosol number concentration. The third term is connected with temperature effects on aerosol number concentration. It is negative, indicating that the greater the temperature, the lower the aerosol number concentration is. The last term shows how $N_{\mathrm{A}}$ depends on rainfall amount during the previous 3 days. It is negative, implying that the greater the RF amount, the lower the $N_{\mathrm{A}}$ is. This is due to the washing-out effect.

Comparison of results of model calculations with $N_{\mathrm{A}}$ measurements (Fig. 10) showed good agreement in the cases when: the effect of continental sources was weak; the wind speed was relatively low $\left(0.5<\mathrm{WS}<10 \mathrm{~m} \mathrm{~s}^{-1}\right)$, which ensured a linear relationship with aerosol concentration; air temperature was in the range of $-2.5<T<16^{\circ} \mathrm{C}$; and rainfall was in the range $0<\mathrm{RF}<44 \mathrm{~mm} \mathrm{~h}^{-1}$. The correlation coefficient of regression model is 0.71 under these conditions (the number of points is 330). That is, Eq. (5) can be used to estimate the particle number concentration, based on three meteorological parameters: WS, $\cdot T$, and RF. The model gives incorrect results when the data of trajectory analysis and ion composition of aerosol samples indicate the effect of continent, as well as in the proximity to large-scale atmospheric vortices (cyclones). It should be noted that regression (Eq. 5) is only valid for data from the route of RV Professor Khljustin. Because of the limited amount of data available for the regression analysis, the same fitting parameters may not be ideal for future measurements.

According to the total set of the average meteorological conditions and the intensity of sources of continental aerosol, the middle and Arctic latitudes exhibit differences which could not help being reflected in specific features of behavior of the number concentrations of submicron (Fig. 9a) and coarsely dispersed (Fig. 9b) aerosol fractions in these regions. The $N_{\mathrm{f}}$ concentration substantially changed at the beginning and end of the expedition (mid-latitudes); while in the middle part (high latitudes), the variability range and the average level of $N_{\mathrm{f}}$ decreased by approximately a factor of 3. Except on the first day of measurements, the concentra- 
a)

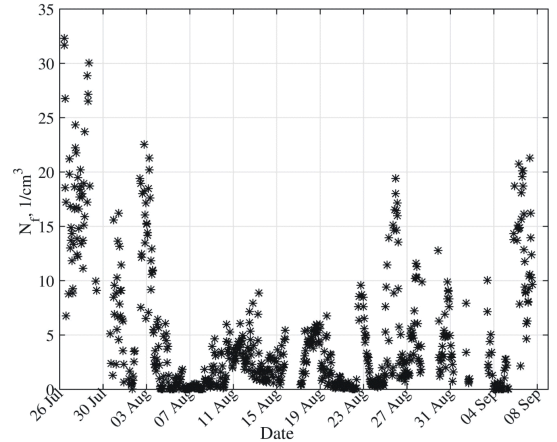

c)

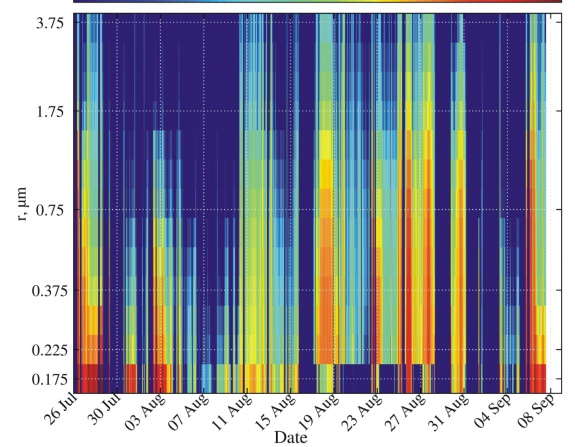

e)

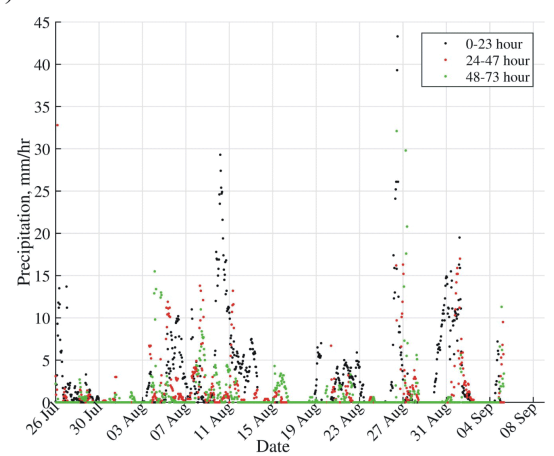

b)

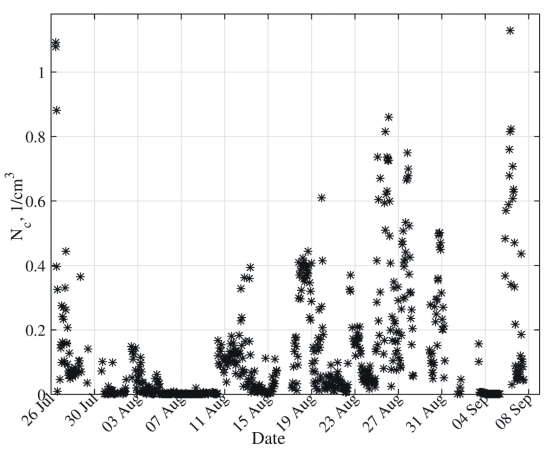

d)

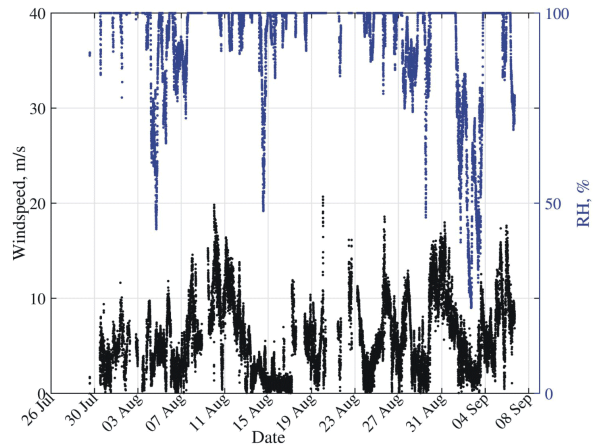

f)

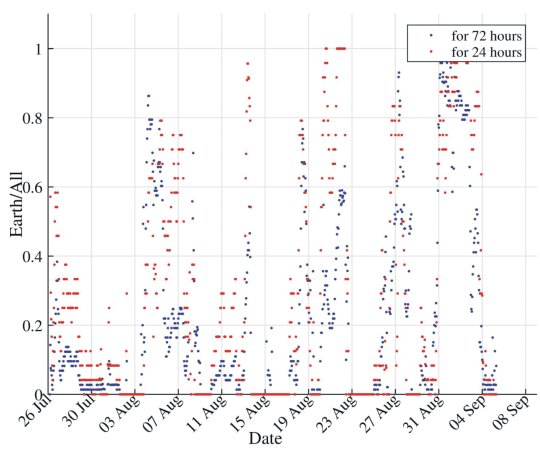

Figure 9. Temporal behavior of the (a) number concentrations of submicron $N_{\mathrm{f}}$ and (b) coarsely dispersed $N_{\mathrm{c}}$ aerosol fractions; (c) the volume particle size distributions $\mathrm{d} V / \mathrm{d} r$; (d) the wind speed (black) and the relative air humidity (blue); (e) the along-trajectory rainfall amount; and (f) the fraction of trajectories passing over land.

tion of coarsely dispersed fraction remained at low level until 10 August, and increased afterward.

These same features are also traced according to the character of change in the aerosol disperse composition (Fig. 9c). The highest $\mathrm{d} V / \mathrm{d} r$ values, with predominance of submicron aerosol, were observed at the beginning and end of cruise, when the vessel was at mid-latitudes, in proximity to, and surrounded by, the land. That is, the aerosol content was formed under the influence of outflows of finely dispersed aerosol from relatively well-developed regions. The remaining period, especially when the vessel was in the Arctic zone, was characterized by a low content of aerosol, with a larger contribution of coarsely dispersed fraction.
Thus, the relative contents of large and small particles are redistributed in the aerosol in transport from middle to high latitudes. The observed increase in the relative role of large particles in subarctic and Arctic regions was noted as early as in O'Dowd and Smith (1993) and is explained by predominance of maritime air masses.

The division of data into two groups (zones) according to the relative contents of two aerosol fractions is clearly confirmed by a scatter diagram of $N_{\mathrm{f}}$ and $N_{\mathrm{c}}$ values (Fig. 11) in the zones of mid-latitude (red) and Arctic (blue) latitudes. The slope coefficient of regression line for the first group of data, obtained in the period from 24 July to 10 August and 37 September, is $\gamma=N_{\mathrm{c}} / N_{\mathrm{f}}=10^{-2}$. A less slope of regression line is caused by the dominating contribution of sub- 


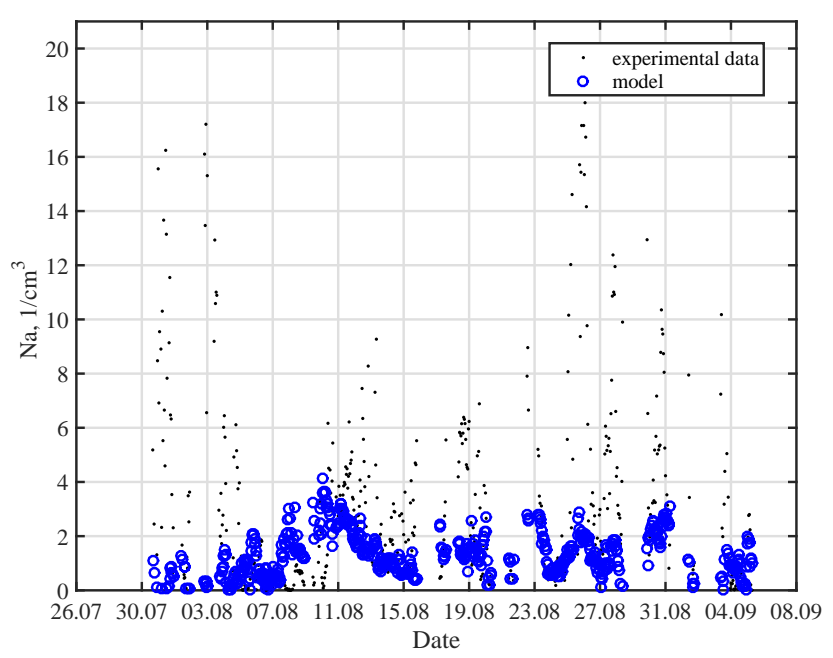

Figure 10. The measured and model (calculated) values of the aerosol number concentration.

micron aerosol at mid-latitudes. A low content of coarsely dispersed maritime aerosol (see Fig. 9b) also explained why the values of the parameter $\gamma$ were low at the beginning of the expedition (until 10 August). This aerosol was weakly generated because of small wind speed (Fig. 9d).

These measurements in Arctic and subarctic regions (on 10-31 August) were characterized by low values of the number concentration and a relative importance of coarsely dispersed fraction, indicating the predominance of maritime aerosol (Bigg et al., 1995; Nilsson et al., 2001). The slope coefficient of regression line is $\gamma=4.5 \times 10^{-2}$ in this case.

The lowest concentrations of the two fractions were observed from 5 to 10 August (the Bering Strait and the Chukchi Sea): the average value of $N_{\mathrm{f}}$ was $0.65 \mathrm{~cm}^{-3}$; and coarsely dispersed particles, despite wind strengthening, were practically absent. This was favored by the washing-out action of rainfall (see Fig. 9e) and supply of clean Arctic air from the direction of Chukchi Peninsula (Fig. 4c). Here, it is important to note that the effect of outflows of continental air is diverse in different regions. At mid-latitudes, the outflows considerably enrich the marine atmosphere by finely dispersed aerosol (most characteristically, the outflows of Asian aerosol to the Japan Sea). In the poorly developed continental Arctic, the aerosol sources are substantially weakened or absent. Therefore, the outflows of air masses from the direction of land (Fig. 4c and d) do not lead to increase of aerosol content in sea water basins.

\section{Chemical composition of the atmosphere on the route of RV Akademik Fedorov and Professor Khljustin}

In addition to the measurements of the optical and microphysical characteristics of aerosol, on the route of two expeditions (Fig. 1) we collected air samples for a subsequent

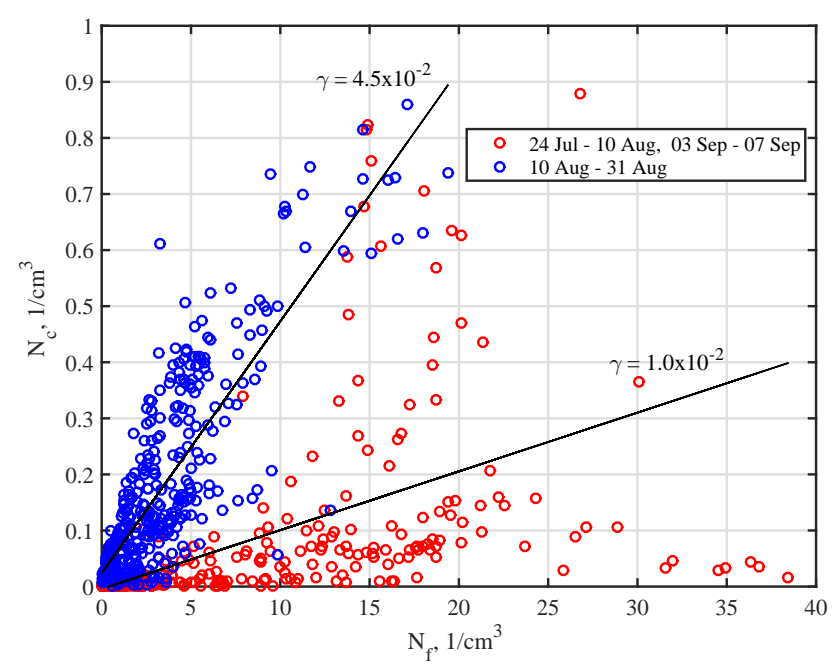

Figure 11. The scatter diagrams of number concentrations of submicron $N_{\mathrm{f}}$ and coarsely dispersed $N_{\mathrm{c}}$ aerosol at middle (red) and high (blue) latitudes.

analysis of ion and elemental composition of aerosol, as well as the content of gas-phase species. In the preliminary analysis of the chemical composition of samples on the route of RV Akademik Fedorov, we considered data for the area of the Barents Sea (region B), as well as three subregions in the high-latitude part of the route (within the region A): (1) area northward of Severnaya Zemlya and Franz Josef Land archipelagos $\left(81-84^{\circ} \mathrm{N}, 68-111^{\circ} \mathrm{E}\right)$; (2) the northwestern part of the Laptev Sea $\left(77-80^{\circ} \mathrm{N}, 107-126^{\circ} \mathrm{E}\right)$; and (3) the northeastern margins of the Laptev Sea $\left(78-81^{\circ} \mathrm{N}\right.$, $\left.127-155^{\circ} \mathrm{E}\right)$. In analysis below, the average characteristics of chemical composition of aerosol will be considered for the region $\mathrm{A}$ as a whole.

The chemical composition of aerosol in the RV Professor Khljustin cruise was determined according to samples, collected on the filters PTFE for five Far East seas: the Japan, Okhotsk, Bering, Chukchi, and East Siberian seas. The last two seas, though adjoining the Far East of Russia, refer to Arctic seas. We will use this name in the current paper simply for brevity of the general name. Taking into account the difference in meteorological conditions over Far East seas, the average characteristics of the chemical composition of aerosol were estimated separately for the forward and return routes of the vessel and for each region as a whole. 
Table 6. Average characteristics of ion composition of atmospheric aerosol on the route of RV Akademik Fedorov and Professor Khljustin (the numerator indicates the average ion content in $\mu \mathrm{g} \mathrm{m}^{-3}$ and standard deviations; the denominator indicates the average values on the forward and return routes; $n$ is the number of samples; and $\sum_{\text {ions }}$ is the summed ion content).

\begin{tabular}{|c|c|c|c|c|c|c|}
\hline \multirow[t]{2}{*}{ Ions } & \multicolumn{6}{|c|}{ Area } \\
\hline & $\begin{array}{c}\text { Region A } \\
(n=14)\end{array}$ & $\begin{array}{c}\text { East Siberian Sea } \\
\quad(n=1 / 1)\end{array}$ & $\begin{array}{l}\text { Chukchi Sea } \\
\quad(n=6 / 2)\end{array}$ & $\begin{array}{c}\text { Bering Sea } \\
(n=3 / 4)\end{array}$ & $\begin{array}{l}\text { Okhotsk Sea } \\
(n=3 / 2)\end{array}$ & $\begin{array}{l}\text { Japan Sea } \\
(n=4 / 1)\end{array}$ \\
\hline $\mathrm{Na}^{+}$ & $0.34 \pm 0.24$ & $\frac{0.27 \pm 0.13}{0.18 / 0.38}$ & $\frac{0.62 \pm 0.98}{0.29 / 1.58}$ & $\frac{0.62 \pm 0.62}{0.38 / 0.80}$ & $\frac{1.00 \pm 1.66}{0.34 / 1.99}$ & $\frac{0.65 \pm 0.40}{0.49 / 1.30}$ \\
\hline $\mathrm{NH}_{4}^{+}$ & $0.13 \pm 0.07$ & 0.00 & 0.00 & $\frac{0.02 \pm 0.02}{0.01 / 0.02}$ & $\frac{0.01 \pm 0.02}{0.02 / 0.00}$ & $\frac{0.05 \pm 0.01}{0.05 / 0.04}$ \\
\hline $\mathrm{K}^{+}$ & $0.04 \pm 0.06$ & $\frac{0.18 \pm 0.11}{0.10 / 0.26}$ & $\frac{0.08 \pm 0.11}{0.04 / 0.19}$ & $\frac{0.26 \pm 0.41}{0.06 / 0.41}$ & $\frac{0.28 \pm 0.43}{0.39 / 0.11}$ & $\begin{array}{l}0.05 / 0.04 \\
0.48 \pm 0.20 \\
0.45 / 0.61\end{array}$ \\
\hline $\mathrm{Mg}^{2+}$ & $0.03 \pm 0.02$ & $\frac{0.02 \pm 0.01}{0.02 / 0.03}$ & $\frac{0.07 \pm 0.11}{0.03 / 0.18}$ & $\frac{0.06 \pm 0.05}{0.04 / 0.08}$ & $\frac{0.13 \pm 0.24}{0.03 / 028}$ & $\frac{0.05 \pm 0.02}{0.05}$ \\
\hline $\mathrm{Ca}^{2+}$ & $0.04 \pm 0.02$ & $\frac{0.04 \pm 0.01}{0.03 / 0.053}$ & $\frac{0.05 \pm 0.06}{0.03 / 0.10}$ & $\frac{0.07 \pm 0.06}{0.03 / 0.10}$ & $\frac{0.10 \pm 0.10}{0.10 / 0.11}$ & $\frac{0.12 \pm 0.05}{0.13 / 0.10}$ \\
\hline $\mathrm{Cl}^{-}$ & $0.66 \pm 0.36$ & $\frac{0.48 \pm 0.25}{0.31 / 0.66}$ & $\frac{0.80 \pm 0.91}{0.53 / 1.60}$ & $\frac{1.09 \pm 1.14}{0.66 / 1.41}$ & $\frac{1.63 \pm 2.57}{0.58 / 3.21}$ & $\frac{1.10 \pm 0.67}{0.82 / 2.23}$ \\
\hline $\mathrm{Br}^{-}$ & $0.01 \pm 0.01$ & $\begin{array}{c}0.001 \pm 0.0 \\
0.001009\end{array}$ & $\frac{0.002 \pm 0.004}{0.001}$ & $\frac{0.002 \pm 0.002}{0.001}$ & $\frac{0.005 \pm 0.010}{0.001}$ & $\frac{0.004 \pm 0.004}{0.004 / 0.003}$ \\
\hline $\mathrm{NO}_{3}^{-}$ & $0.03 \pm 0.04$ & $\frac{0.001}{0.001}$ & $\begin{array}{r}0.005 \pm 0.010 \\
0.00007 .00\end{array}$ & $\begin{array}{l}0.011 \pm 0.020 \\
0.010\end{array}$ & $\begin{array}{r}0.001 / 0.011 \\
0.005 \pm 0.011 \\
00.012\end{array}$ & $\begin{array}{l}0.004 / 0.003 \\
0.110 \pm 0.085 \\
\end{array}$ \\
\hline $\mathrm{SO}_{4}^{2-}$ & $0.11 \pm 0.07$ & $\frac{0.069 \pm 0.003}{0.060310 .071}$ & $\frac{0.25 \pm 0.35}{0.13 / 0.60}$ & $\begin{array}{l}0.0 / 0.019 \\
0.84 \pm 0.89 \\
034 / 122\end{array}$ & $\begin{array}{l}0.0 / 0.013 \\
0.42 \pm 0.47 \\
0.29 / 0.61\end{array}$ & $\begin{array}{c}0.103 / 0.140 \\
\frac{0.58 \pm 0.21}{0.66 / 0.28}\end{array}$ \\
\hline$\Sigma_{\text {ions }}$ & $1.39 \pm 0.75$ & $\frac{1.06 \pm 0.52}{0.72 / 1.45}$ & $\frac{1.88 \pm 2.50}{1.06 / 4.26}$ & $\frac{2.97 \pm 1.96}{1.52 / 4.06}$ & $\frac{3.58 \pm 5.07}{1.75 / 6.33}$ & $\frac{3.14 \pm 1.09}{2.75 / 4.67}$ \\
\hline
\end{tabular}

\subsection{Ion composition of aerosol}

Preliminary analysis of aerosol samples, collected in the high-latitude part of the route of RV Akademik Fedorov (region A) showed that most ions had higher concentrations in the northwestern part of the Laptev Sea (the mean concentrations $\Sigma_{\text {ions }}=1.71 \mu \mathrm{g} \mathrm{m}^{-3}$ ). However, the existing differences in concentrations are not large and much smaller than the standard deviations. Therefore, the average characteristics of the chemical composition of aerosol were calculated for the region A as a whole (Table 6).

A much larger difference in ion composition is observed for two samples, collected in the area of the Barents Sea (region B): both summed content (the average $\Sigma_{\text {ions }}=$ $0.61 \mu \mathrm{g} \mathrm{m}^{-3}$ ), and concentrations of individual ions (except $\mathrm{K}^{+}$) are about 2 times smaller than the average concentrations over the Arctic Ocean. The data in region B had insufficiently representative statistics and, as such, were excluded from further analysis.

From comparison with our previous data in other Arctic regions we can draw the following conclusions. The averaged summed ion content in region A agrees well with data obtained in July-August 2011 in Barentsburg (Svalbard archipelago, $\sim 78^{\circ} \mathrm{N}$ ) (Golobokova et al., 2013): the average $\Sigma_{\text {ions }}=1.41 \mu \mathrm{g} \mathrm{m}^{-3}$. In more southern seas, in the adjoining continent, the ion content is much larger (Polkin et al., 2011a): by about an order of magnitude $\left(17.1 \mu \mathrm{g} \mathrm{m}^{-3}\right)$ over the subarctic White Sea, and by almost a factor of 6 $\left(8.9 \mu \mathrm{g} \mathrm{m}^{-3}\right)$ over the Kara Sea. Clearly, the atmosphere of these seas is under a stronger influence of continental aerosol sources, contributing about $38 \%$ in the White Sea, $30 \%$ in central regions of the Kara Sea, and 60-80\% in coastal water basins of the Kara Sea (Polkin et al., 2011a).
The average ion concentrations in aerosol composition over Far East seas vary in quite a wide range (see Table 6). The average ion concentrations differ not only among separate seas, but also in the same regions on the forward and return routes of RV Professor Khljustin. The ions $\mathrm{Na}^{+}, \mathrm{Mg}^{2+}$, $\mathrm{K}^{+}, \mathrm{Cl}^{-}$and $\mathrm{SO}_{4}^{2-}$ exhibit the strongest variations. For the first half of the cruise, the total sum of ions and contents of individual ions distinctly show a tendency of their latitudinal distribution (Fig. 12). As the ship moved from low to high latitudes, the total concentration of ions in the near-water aerosol decreased by approximately $30 \%$. A little weaker gradient (a decrease by $13 \%$ ) was observed during transit from the Okhotsk to Bering Sea.

Data that were collected on the return route of the vessel exhibited stronger spatiotemporal variations in ion content, and the regularity of their latitudinal growth was not distinctly manifested. This was primarily because, on the return route, in the aerosol composition there was a much larger (a factor of 2-9) contribution from sea-derived ions, i.e., $\mathrm{Na}^{+}, \mathrm{Mg}^{2+}$ and $\mathrm{Cl}^{-}$, the generation of which was caused by stronger sea surface roughness, rather than by the geographic position of the region.

Despite the strong variations and difference in the data between the forward and return routes of RV Professor Khljustin, the average (over regions) ion concentrations nonetheless exhibit a tendency of their northward decrease.

We also note that the average ion concentrations in the Far East sector of the Russian Arctic (Chukchi and East Siberian seas) are close in value to the average data in the central part (region A). That is, the variations and differences in ion composition over Arctic seas were mainly caused not by spatial inhomogeneities, but, rather, by weather features in the periods of measurements. 
The maritime component of sodium and chloride ions predominated in aerosol composition on the route of both expeditions (Akademik Fedorov and Professor Khljustin). Their maximal percentages of the total sum of ions were $70.8 \%$ over the Arctic Ocean and $57.9 \%$ over Far East seas. This agrees with data from Chinese National Arctic Research Expedition (FCNARE, 1999-2003) (Sun, 2002; Xu et al., 2005), performed along a route close to that of RV Professor Khljustin. Percentage of sea-derived ions was $60.2 \%$ in FCNARE expeditions.

For other ions (except for $\mathrm{Na}^{+}$and $\mathrm{Cl}^{-}$) the concentrations can be lined up as follows (in order of decreasing): $\mathrm{NH}_{4}^{+}>\mathrm{K}^{+}, \mathrm{Mg}^{2+}>\mathrm{Ca}^{2+}$ in high-latitude regions of Arctic; $\mathrm{K}^{+}>\mathrm{Mg}^{2+}>\mathrm{Ca}^{2+}>\mathrm{NH}_{4}^{+}$in the Bering, Chukchi, and East Siberian seas; and $\mathrm{K}^{+}>\mathrm{Ca}^{2+}>\mathrm{Mg}^{2+}>\mathrm{NH}_{4}^{+}$in the Japan and Okhotsk seas. The $\mathrm{SO}_{4}^{2-}$ concentrations are larger than $\mathrm{NO}_{3}^{-}$concentrations in all regions of the Northern Sea Route.

A characteristic feature of ion composition of aerosol over the Japan and Okhotsk seas is very high concentrations of $\mathrm{K}^{+}$, exceeding those over Arctic seas by about an order of magnitude. This is possibly due to the effect of active volcanoes of the Kamchatka Peninsula and Kuril Islands, which predominately release moderate-potassium-type magmas (Ponomareva et al., 2012). In contrast to our data, no elevated percentage of $\mathrm{K}^{+}$was observed in FCNARE expedition (Sun, 2002; $\mathrm{Xu}$ et al., 2005); with respect to average percentage composition, $\mathrm{NH}_{4}^{+}$and $\mathrm{SO}_{4}^{2-}$ ions (summing to $27 \%$ ) were ranked next behind $\mathrm{Na}^{+}$and $\mathrm{Cl}^{-}$in this case.

Still another salient feature is higher $\mathrm{NO}_{3}^{-}$concentrations obtained in FCNARE: $0.94 \mu \mathrm{g} \mathrm{m}^{-3}$ for the Japan Sea, and $0.11 \mu \mathrm{g} \mathrm{m}^{-3}$ for the Okhotsk and Bering seas. Sun (2002) and $\mathrm{Xu}$ et al. (2005) suggest that the $\mathrm{NO}_{3}^{-}$ions are indicators of anthropogenic impact, and their elevated content over the Japan Sea was also reported elsewhere (see, e.g., Sasakawa and Uematsu, 2002). The $\mathrm{NO}_{3}^{-}$concentrations over the Japan Sea, measured in our expedition, were much lower than in FCNARE data, but they were also higher than over other seas. Presumably, our measurements were performed only in the northern part of the Japan Sea, less subject to anthropogenic outflows, explaining smaller $\mathrm{NO}_{3}^{-}$concentrations. It should be also be remembered that, given limited number of samples collected in separate regions, chemical analysis results may substantially differ among diverse expeditions, reflecting not the specific character of the region, but rather specific features of meteorological conditions (and, primarily, air transports) in particular periods of measurements.

We used the well-known formulas to calculate the percentages of sea-salt (ss-) and non-sea-salt (nss-) sulfates (EMEP, 1996):

$$
\begin{aligned}
{\left[\mathrm{nss}-\mathrm{SO}_{4}^{2-}\right] } & =\left[\mathrm{SO}_{4}^{2-}\right]-0.06028\left[\mathrm{Na}^{+}\right] \\
{\left[\mathrm{ss}^{+} \mathrm{SO}_{4}^{2-}\right] } & =\left[\mathrm{SO}_{4}^{2-}\right]-\left[\mathrm{nss}-\mathrm{SO}_{4}^{2-}\right],
\end{aligned}
$$

where $\left[\mathrm{SO}_{4}^{2-}\right]$ is the sulfate concentration, $\left[\mathrm{Na}^{+}\right]$is the sodium concentration in aerosol; 0.06028 is the relationship of concentrations $\mathrm{SO}_{4}^{2-} / \mathrm{Na}^{+}$for ions of seawater; the initial content of components is represented in molar concentration (mol L ${ }^{-1}$ ).

The calculations showed that seawater was the main source of sulfates on the routes of two expeditions. Among the high-latitude regions, the high percentage (up to $100 \%$ ) of ss- $\mathrm{SO}_{4}^{2-}$ was observed mainly over the Laptev Sea, where air came from the central part of the Arctic Ocean. The minimal percentage of $\mathrm{ss}^{-\mathrm{SO}_{4}^{2-}}$ in aerosol was recorded on 13-17 September 2013 northward of Severnaya Zemlya archipelago. The percentage of non-sea-salt sulfates (nss$\mathrm{SO}_{4}^{2-}$ ) reached $74 \%$ in this region.

On the route of RV Professor Khljustin, the maximal percentage $(100 \%)$ of $\mathrm{ss}_{-} \mathrm{SO}_{4}^{2-}$ in aerosol was observed over the East Siberian, Bering, and Japan seas on the return route of the vessel under the conditions of growing wind speed (15$20 \mathrm{~m} \mathrm{~s}^{-1}$ ) and sea roughness (Beaufort numbers of 3-4). The large percentage (up to $88.7 \%$ ) of non-sea-salt sulfates was recorded over the Japan Sea during an extended vessel drift in the region of Sakhalin Island.

It is well known that series of concentrations of elements in seawater and maritime aerosol coincide. According to the Dittmar law, the quantitative relationships between principal components of the main salt composition are always constant in seawater samples. We quantitatively estimated the differences in relationships of the $\mathrm{Ca}^{2+}, \mathrm{K}^{+}, \mathrm{Mg}^{2+}, \mathrm{Cl}^{-}, \mathrm{SO}_{4}^{2-}$ concentrations with respect to sodium ion in aerosol (aer) and seawater (sw):

$K_{i}=\left[\left(C_{i} / \mathrm{Na}^{+}\right)_{\mathrm{aer}}\right] /\left[\left(C_{i} / \mathrm{Na}^{+}\right)_{\mathrm{sw}}\right]$,

where $\left(C_{i} / \mathrm{Na}^{+}\right)$is the concentration of the $i$ th element with respect to $\mathrm{Na}^{+}$, and $K$ is the enrichment coefficient (Tsunogai et al., 1972).

The ratios $\left(\mathrm{K}^{+} / \mathrm{Na}^{+}\right)_{\text {aer }}$ and $\left(\mathrm{Na}^{2+} / \mathrm{Na}^{+}\right)_{\text {aer }}$ larger than in seawater were recorded on the route of RV Akademik Fedorov. Maximal enrichment of aerosol, especially by potassium (by up to a factor of 18), was observed on 23-24 August 2013 at northern margins of the Kara Sea (in the region of Severnaya Zemlya islands). Analysis of 10-day trajectories of motion of air masses showed that, in this period, they formed and came (at $3 \mathrm{~km}$ level) to the region of measurements from the following directions: from western $\mathrm{Eu}-$ rope across Kola Peninsula on 23 August; and over the area of the Arctic Ocean along the trajectory of Svalbard-Franz Josef-New Siberian Islands-Taimyr on 24 August. At lower heights, the air masses moved within the Arctic Ocean. Thus, using these data, it is difficult to identify the sources or causes for such potassium-rich substances. 


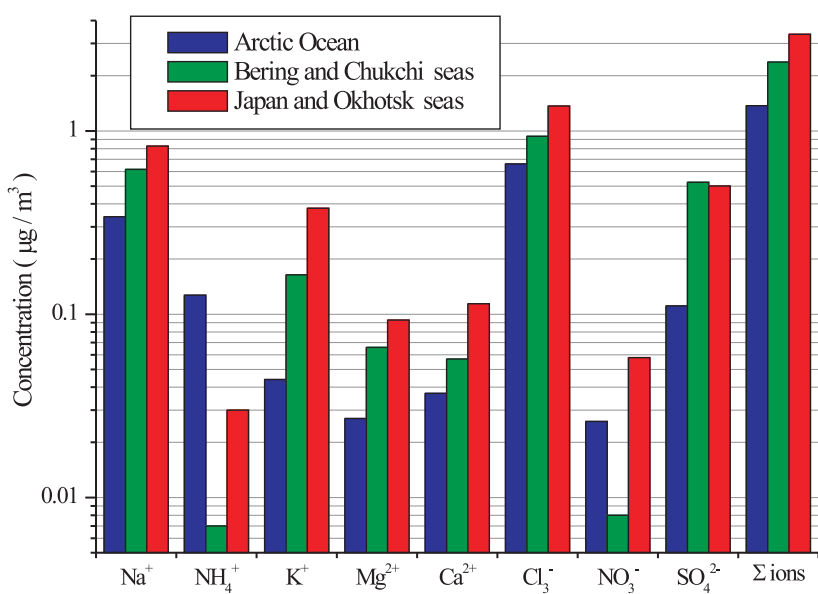

Figure 12. Average ion content in aerosol over Arctic and Far East seas.

The literature, available to us, provides no unambiguous data on the sources of $\mathrm{K}$ - and Ca-enriched substances in this region of the Arctic Ocean, located hundreds to thousands of kilometers away from the continent. Fractionation of sea salts from snow and ice is known to be one of the mechanisms by which aerosol particles are enriched, especially by sulfates and sodium (Domine et al., 2004; Hara et al., 2012). Ship emissions usually influence the arrival of pollutants to the Arctic atmosphere (Zhan et al., 2014); however, ships usually cruise southward of the regions considered here. Far-range transport of pollutants from the northern margins of the continent may also have an effect. For instance, observations at the coastal station of Kevo, northern Finland (from 1964 to 1978), revealed, together with nonferrous metals in mosses (indicators of atmospheric air pollution), also a tenfold increase in potassium, which is the main marker of biomass burning. In addition, $\mathrm{Na}, \mathrm{K}$, and $\mathrm{Ca}$ arrive at this region from different Kola industrial areas (Yli-Tuomi et al., 2003). Enrichment of sphagnum mosses by components of aerotechnogenic pollution is observed in polar regions of Russia (Shevchenko, 2006). Supply of pollutants to the central regions of Arctic together with air masses from northern Europe and industrial centers of Russia was repeatedly indicated in Vinogradova and Ponomareva (2007) and Vinogradova (2014).

On the route of RV Professor Khljustin, maximal enrichment ( $K=13-34$ ) was revealed, as expected, for $\mathrm{K}^{+}$ions over water basins of the Japan and Okhotsk seas. The enrichment coefficient was also high for calcium: the ratio $\left(\mathrm{Ca}^{2+} / \mathrm{Na}^{+}\right)_{\text {aer }}$ exceeded $\left(\mathrm{Ca}^{2+} / \mathrm{Na}^{+}\right)_{\mathrm{sw}}$ by a factor of $2-$ 15. Maximal enrichment of sulfates in aerosol was observed over the Bering Sea on 28 August: $\left(\mathrm{SO}_{4}^{2-} / \mathrm{Na}^{+}\right)_{\text {aer }}$ exceeded $\left(\mathrm{SO}_{4}^{2-} / \mathrm{Na}^{+}\right)_{\mathrm{sw}}$ by as much as the factor of 67 . On that day, air masses passed across Kamchatka Peninsula before reaching the sampling point. Maximal enrichment of aerosol by sulfates is observed occasionally in the Bering Sea and, as such, is atypical for this region.

The excess of $\left(\mathrm{SO}_{4}^{2-} / \mathrm{Na}^{+}\right)$aer was, on average, a factor of 5 over the Japan Sea and a factor of 2-3 over other seas. Emissions of sulfur-containing gases from magmas are one of the sources of sulfates in the region of active volcanoes (Ponomareva et al., 2012). Moreover, as compared to northern seas, the atmosphere of the Japan and Okhotsk seas experiences stronger anthropogenic impact, not only due to regional sources, but also as a consequence of trans-boundary transport of pollutants from China, Korea, and Japan (Luangjame, 2013; Toyama et al., 2013). Our studies of aerosol components, performed in the Japan and Okhotsk seas in 2009 and 2010 (Pol'kin and Golobokova, 2011), showed that dust, anthropogenic, and smoke outflows from Asian continent were responsible for up to a factor of 136 enrichment of aerosol particles in the Japan Sea by sulfates and for up to the factors of 60 and 81 enrichment by potassium and calcium.

Because of the considerable dependence of aerosol characteristics on hydrometeorological conditions, given the limited time and the number of samples taken, we could not determine the average chemical composition, characteristic of separate seas. Therefore, we will conclude this section by presenting ion concentrations averaged over three larger sea water basins, where no fewer than ten aerosol samples were collected:

1. remote regions of the Arctic (region A, $n=14$ ), which are less subject to the effect of continental aerosol outflows, while their own sources are weak;

2. polar and subpolar seas (Chukchi and Bering seas, $n=15$ ), which, although located near Asian coasts, are nonetheless characterized by low-intensity aerosol sources;

3. Far East seas at mid-latitudes (the Japan and Okhotsk seas, $n=10$ ), most subject to the effect of continental aerosol outflows.

From these results (see Fig. 12) it follows that the average concentrations of most ions and their sum increase in the above-mentioned sequence of three regions. For instance, the summed concentration of ions, as compared to the Arctic Ocean, increases by $73 \%$ over the Bering and Chukchi seas, and by a factor of 2.5 over the Japan and Okhotsk seas. Exceptions are the ions $\mathrm{NH}_{4}^{+}$and $\mathrm{NO}_{3}^{-}$, the average concentration of which is lowest over the Bering and Chukchi seas (smaller than in remote regions of the Arctic Ocean). Another salient feature is characteristic of ions $\mathrm{SO}_{4}^{2-}$, the concentration of which is nearly the same in southern and northern Far East seas.

\subsection{Elemental composition of aerosol}

First measurements of elemental composition in solid-phase aerosol, performed in 1985-1988 on the Wrangel and Sever- 
Table 7. Average values $( \pm \mathrm{SD})$ of concentrations $\left(\mathrm{ng} \mathrm{m}^{-3}\right)$ of water-soluble elements in aerosol along the route of RV Akademik Fedorov and Professor Khljustin (July-September 2013).

\begin{tabular}{|c|c|c|c|c|c|c|}
\hline \multirow[t]{2}{*}{ Element } & \multicolumn{6}{|c|}{ Area } \\
\hline & $\begin{array}{l}\text { Arctic Ocean } \\
\text { (A) }\end{array}$ & $\begin{array}{c}\text { East Siberian } \\
\text { Sea }\end{array}$ & Chukchi Sea & Bering Sea & Okhotsk Sea & Japan Sea \\
\hline $\mathrm{Fe}$ & $6.06 \pm 4.22$ & $0.55 \pm 0.061$ & $2.1 \pm 1.5$ & $2.0 \pm 1.0$ & $2.6 \pm 3.1$ & $6.1 \pm 5.0$ \\
\hline $\mathrm{Zn}$ & $8.71 \pm 4.81$ & $10.3 \pm 5.8$ & $20.3 \pm 13.7$ & $11.0 \pm 2.1$ & $35.5 \pm 31.4$ & $36.1 \pm 11.6$ \\
\hline $\mathrm{Al}$ & $0.70 \pm 1.33$ & $0.29 \pm 0.032$ & $1.6 \pm 2.3$ & $5.1 \pm 7.2$ & $5.6 \pm 6.7$ & $2.2 \pm 0.8$ \\
\hline $\mathrm{Cu}$ & $1.08 \pm 0.72$ & $3.0 \pm 1.6$ & $2.9 \pm 1.1$ & $3.9 \pm 2.1$ & $5.2 \pm 5.2$ & $8.1 \pm 3.1$ \\
\hline $\mathrm{Sr}$ & $0.65 \pm 0.38$ & $1.06 \pm 0.72$ & $0.61 \pm 0.74$ & $0.64 \pm 0.54$ & $1.10 \pm 1.29$ & $1.03 \pm 0.31$ \\
\hline $\mathrm{Mn}$ & - & $0.20 \pm 0.18$ & $1.19 \pm 1.04$ & $0.11 \pm 0.16$ & $1.40 \pm 1.99$ & $1.51 \pm 1.71$ \\
\hline $\mathrm{Ba}$ & $0.99 \pm 0.44$ & $1.05 \pm 0.076$ & $1.0 \pm 0.4$ & $1.0 \pm 0.3$ & $0.97 \pm 0.50$ & $2.1 \pm 0.3$ \\
\hline $\mathrm{Ni}$ & $0.27 \pm 0.25$ & $0.21 \pm 0.08$ & $0.62 \pm 1.13$ & $0.32 \pm 0.35$ & $0.41 \pm 0.51$ & $0.98 \pm 0.46$ \\
\hline $\mathrm{Cd}$ & $0.36 \pm 0.19$ & $0.050 \pm 0.030$ & $0.074 \pm 0.029$ & $0.14 \pm 0.21$ & $0.09 \pm 0.05$ & $0.11 \pm 0.06$ \\
\hline $\mathrm{Cr}$ & $0.100 \pm 0.074$ & $0.031 \pm 0.031$ & $0.078 \pm 0.076$ & $0.37 \pm 0.41$ & $0.14 \pm 0.13$ & $0.24 \pm 0.06$ \\
\hline $\mathrm{Se}$ & $0.141 \pm 0.068$ & $0.23 \pm 0.07$ & $0.10 \pm 0.13$ & $0.050 \pm 0.078$ & $0.06 \pm 0.08$ & $0.22 \pm 0.14$ \\
\hline $\mathrm{Pb}$ & $0.086 \pm 0.038$ & $0.16 \pm 0.03$ & $0.22 \pm 0.06$ & $0.25 \pm 0.16$ & $0.28 \pm 0.23$ & $0.41 \pm 0.12$ \\
\hline $\mathrm{V}$ & $0.024 \pm 0.010$ & $0.15 \pm 0.03$ & $1.22 \pm 2.84$ & $0.093 \pm 0.069$ & $0.16 \pm 0.17$ & $0.74 \pm 0.67$ \\
\hline Mo & $0.047 \pm 0.019$ & $0.024 \pm 0.010$ & $0.023 \pm 0.014$ & $0.016 \pm 0.016$ & $0.023 \pm 0.024$ & $0.039 \pm 0.025$ \\
\hline $\mathrm{Ti}$ & $0.064 \pm 0.189$ & 0.00 & $0.009 \pm 0.023$ & $0.003 \pm 0.007$ & 0.00 & $0.026 \pm 0.036$ \\
\hline $\mathrm{Co}$ & $0.003 \pm 0.013$ & $0.007 \pm 0.010$ & $0.005 \pm 0.010$ & $0.002 \pm 0.006$ & $0.007 \pm 0.010$ & $0.015 \pm 0.011$ \\
\hline $\mathrm{Sb}$ & $0.126 \pm 0.438$ & $0.014 \pm 0.001$ & $0.023 \pm 0.016$ & $0.013 \pm 0.004$ & $0.046 \pm 0.048$ & $0.065 \pm 0.049$ \\
\hline $\mathrm{Li}$ & $0.0049 \pm 0.0079$ & $0.044 \pm 0.041$ & $0.049 \pm 0.053$ & $0.023 \pm 0.022$ & $0.040 \pm 0.040$ & $0.077 \pm 0.037$ \\
\hline As & $0.0057 \pm 0.0042$ & $0.014 \pm 0.013$ & $0.012 \pm 0.017$ & $0.005 \pm 0.012$ & $0.023 \pm 0.042$ & $0.034 \pm 0.035$ \\
\hline $\mathrm{Be}$ & 0.00 & $0.0012 \pm 0.0021$ & $0.0002 \pm 0.0005$ & $0.0001 \pm 0.0002$ & $0.0002 \pm 0.0004$ & $0.0002 \pm 0.0003$ \\
\hline$\Sigma_{\mathrm{TE}}$ & 19.42 & 17.39 & 32.13 & 25.04 & 53.65 & 60.10 \\
\hline
\end{tabular}

naya Zemlya islands, made it possible to obtain information on aerosol composition and sources in the Russian sector of the Arctic. Subsequent studies determined the mineral and chemical composition of solid-phase aerosol, the aerosol particle size distribution, the transport pathways of eolian material, and the degree of pollution of the Arctic atmosphere by anthropogenic pollutants; also, these data were used to identify the groups of elements associated with terrigenous (Fe, $\mathrm{Al}, \mathrm{Mn})$, marine $(\mathrm{Na}, \mathrm{Cl})$, and anthropogenic $(\mathrm{Co}, \mathrm{Sb}, \mathrm{Zn}, \mathrm{Pb})$ sources (Shevchenko, 2006; Vinogradova and Ponomareva, 2007).

In oceanic waters, practically all elements are in dissolved form and play an important role in formation of the chemical composition of maritime aerosol. Analysis of elemental composition of the water-soluble aerosol fraction (see Table 7 and Fig. 13) demonstrated the variety and wide (reaching 4-5 orders of magnitude) variability range of absolute concentrations of elements. The highest concentrations of most elements were characteristic of aerosol over the Sea of Japan, and the lowest concentrations for aerosol over the East Siberian Sea. The concentrations of $\mathrm{Fe}, \mathrm{Cd}, \mathrm{Sb}, \mathrm{Ti}$, and Mo over the Arctic Ocean (region A) are equal to or higher than those over Far East seas. The situation was opposite for $\mathrm{Cu}, \mathrm{Al}, \mathrm{V}, \mathrm{Ni}, \mathrm{Pb}$, and $\mathrm{Li}$, the concentrations of which were smaller in region $\mathrm{A}$.
For the average summed content of elements, a common tendency is northward decrease: $\Sigma_{\mathrm{TE}}$ ranges from 54 to $60 \mathrm{ng} \mathrm{m}^{-3}$ over mid-latitude seas and from 17 to $32 \mathrm{ng} \mathrm{m}^{-3}$ over polar and subpolar Far East seas, and $\Sigma_{\mathrm{TE}}$ is about $19 \mathrm{ng} \mathrm{m}^{-3}$ in the high-latitude area of the Arctic Ocean.

With respect to content of water-soluble elements in the aerosol composition, we can single out three groups: (1) with concentrations from several tens to several tenths of $\mathrm{ng} \mathrm{m}^{-3}$, (2) from several tenths to several hundredths of $\mathrm{ng} \mathrm{m}^{-3}$, and (3) from several thousandths to analytical zero. Metals of predominately terrigenous origin, i.e., $\mathrm{Fe}, \mathrm{Zn}, \mathrm{Al}$, Ba, as well as $\mathrm{Cu}$ and $\mathrm{Sr}$, refer to the first group. The elements in the first group totaled $93.4 \%$ of all analyzed microelements. The second group included $\mathrm{Ni}, \mathrm{Cd}, \mathrm{Cr}, \mathrm{Se}, \mathrm{Pb}, \mathrm{V}$, Mo $(5.6 \%$ of the total composition), which are mostly the markers of anthropogenic pollution. The third group consists of $\mathrm{Ti}, \mathrm{Co}, \mathrm{Sb}$, $\mathrm{Li}$, and As ( $0.6 \%$ of the total composition). Elements in this group originate from both natural and anthropogenic sources.

For insoluble fraction of Arctic aerosols, Shevchenko (2006) showed that the content of most terrigenous chemical elements $(\mathrm{Na}, \mathrm{Al}, \mathrm{K}, \mathrm{Ca}, \mathrm{Fe}, \mathrm{Co}$, and $\mathrm{Ba}$ ) in aerosol composition is lower than the average values, characteristic of Earth's crust; while the content of such elements as $\mathrm{Cr}, \mathrm{Cu}, \mathrm{Zn}, \mathrm{As}, \mathrm{Se}, \mathrm{Br}, \mathrm{Ag}, \mathrm{Sb}, \mathrm{Ni}$, and $\mathrm{Pb}$ is much higher, suggesting their predominately anthropogenic origins. Moreover, it is indicated that some 


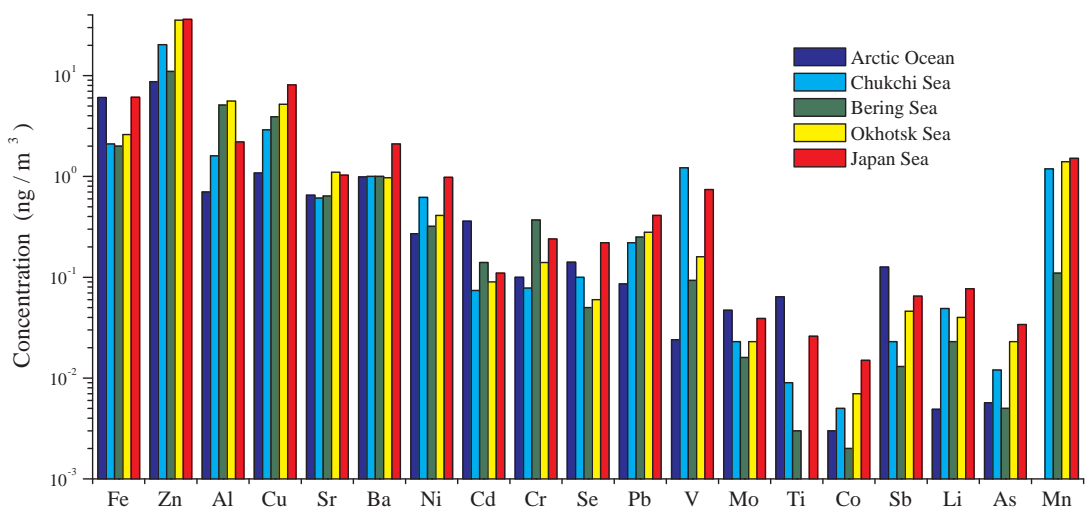

Figure 13. Average concentrations of elements in aerosol composition over Arctic and Far East seas.

elements with high concentrations $(\mathrm{Zn}, \mathrm{Se}$, and $\mathrm{Fe})$ may be both anthropogenic and coming from natural sources.

The data obtained were used to estimate the relative content of soluble elements in the total sum of ions (Table 6) and elements (Table 7) of the water-soluble aerosol fraction. The calculations showed that the average content of elements decreases in the northern direction (except in the Bering Sea): $1.9 \%$ in the Japan Sea, $1.5 \%$ in the Okhotsk Sea, $0.8 \%$ in the Bering Sea, $1.7 \%$ in the Chukchi Sea, $1.6 \%$ in the East Siberian Sea, and $1.4 \%$ in region A. In the Far East sector, the maximal percentage of soluble elements was recorded on 30 July over the Okhotsk Sea (up to $13.8 \%$ ) and on $14 \mathrm{Au}-$ gust over the Chukchi Sea (up to 8.6\%). In region A (RV Akademik Fedorov) the percentage of soluble elements was maximal at the northeastern margins of the Laptev Sea.

Deficient information on measurements of elemental composition of the water-soluble aerosol fraction in these regions (and especially over the Arctic Ocean) complicates the data comparison. Therefore, the composition of the water-soluble aerosol fraction in region A was compared with that of solid aerosol suspensions (soluble and insoluble particles) in the western part of the Russian Arctic during summer-fall period of 2006 (Goryunova and Shevchenko, 2008). The comparison showed that the $\mathrm{Na}, \mathrm{Ca}, \mathrm{Co}, \mathrm{Ni}, \mathrm{Se}, \mathrm{As}, \mathrm{Sr}, \mathrm{Sb}$, and $\mathrm{Ba}$ concentrations in water-soluble fraction (our data) are smaller than in solid-phase aerosol suspension. The soluble percentage was, on average, $11.4-19.2 \%$ for sodium, 7.9$18.8 \%$ for calcium, and about $4 \%$ for barium. The soluble percentages for other elements vary in wider ranges. The maximal percentages were found to be $39.7-60 \%$ for selenium, $0.5-30 \%$ for nickel, and about $5 \%$ (4.8-6.2) for antimony. Other percentages were $0.1-4.2 \%$ for cobalt, $1.0-1.6$ for arsenic, and $0.1-4.3 \%$ for strontium. Despite their low concentrations, these elements play a very important role in wildlife. When entering the environment, the elements penetrate trophic chains, accumulate in plant and animal organisms, become involved in metabolic cycles, and cause diverse physiological distortions.
In analogy to the main ions in aerosol, we also calculated the enrichment coefficients of concentrations of elements with respect to sodium $\left(K=\left(C_{i} / \mathrm{Na}\right)_{\mathrm{aer}} /\left(C_{i} / \mathrm{Na}\right)_{\mathrm{sw}}\right.$. On the whole, on both routes, the enrichment of particles for most chemical elements in soluble aerosol fraction was lower than the average values, characteristic of seawater. High enrichment is revealed for seven elements, namely, $\mathrm{Zn}, \mathrm{Cu}, \mathrm{Al}$, $\mathrm{Fe}, \mathrm{Mn}, \mathrm{Cr}$, and $\mathrm{Cd}$. With respect to intensity of pollution of aerosol by these elements, the study regions can be lined up as follows: Okhotsk Sea, Arctic Ocean, Chukchi Sea, Japan Sea, Bering Sea, and East Siberian Sea.

The aerosol component with enriched elements was recorded on the entire route of RV Akademik Fedorov. The enrichment coefficients for the elements varied in the following ranges: $K=8.8-794$ for Cd, $K=1.2-264$ for $\mathrm{Cr}, K=$ 4.8-72.8 for $\mathrm{Zn}, K=2.0-34.4$ for $\mathrm{Cu}, K=1.1-1.6$ for $\mathrm{Ni}$, $K=0.1-45.3$ for Al, and $K=2.7-88.8$ for Fe. The maximal enrichment of particles was observed northward of the Severnaya Zemlya archipelago from 11 to 18 September. According to several studies (Yli-Tuomi et al., 2003; Shevchenko, 2006; Vinogradova and Ponomareva, 2007; Vinogradova, 2014), the main suppliers of heavy metals to the central Arctic are the Murmansk region $(\mathrm{Ni}, \mathrm{Cu}, \mathrm{Cd})$, the Arkhangelsk region ( $\mathrm{Zn}, \mathrm{Cr})$, Nenets Autonomous Okrug $(\mathrm{Zn}, \mathrm{Pb}, \mathrm{Cr}, \mathrm{Cu})$, the Sverdlovsk region $(\mathrm{Cd}, \mathrm{As}, \mathrm{Zn}, \mathrm{Cr})$, the Norilsk industrial region $(\mathrm{Ni}, \mathrm{Pb})$, and the Kola Peninsula ( $\mathrm{Zn}, \mathrm{Sb}, \mathrm{As}, \mathrm{In})$.

We note that high enrichment of aerosol particles by elements may also be observed in regions farther removed from anthropogenic sources. For instance, enrichment by Al, Fe, $\mathrm{Mn}, \mathrm{Ni}, \mathrm{Cd}$, and $\mathrm{Se}$ was revealed in the eastern sector of the coastal part of Antarctica between China's Zhongshan Station and Australia's Casey Station (Xu and Yuan Gao, 2014). The coefficients of enrichment by $\mathrm{Al}, \mathrm{Fe}$, and Ni near the stations $(K<10)$ turned out to be comparable to or lower than data, which we obtained in the Arctic region A $(K=1-100)$. High enrichments by $\mathrm{Cd}$ in the southern and northern polar regions are in the same range of values $(100<K<1000)$. The two high-latitude regions showed considerable difference in the coefficients of enrichment by Se: the average 
$K=1.3$ in region $\mathrm{A}$, and $K$ is greater than $10^{4}$ in the region of Antarctic stations.

On the route of RV Professor Khljustin, high enrichment coefficients, reaching 3-4 orders of magnitude, were recorded for $\mathrm{Zn}$ and $\mathrm{Cr}$. For zinc, the largest enrichment coefficients were observed over water basins of the Okhotsk ( $K=36-1204)$ and Chukchi seas $(K=17-352)$. Over other Far East seas, the enrichment coefficients for $\mathrm{Zn}$ varied in the range of 2 orders of magnitude $(K=10-97)$. The maximal pollution by chromium compounds was recorded in the atmosphere of the Bering Sea $(K=10-1143)$. Over other seas, the enrichment coefficients for $\mathrm{Cr}$ had the following values: $K=73-181$ for the Japan Sea, $K=90-224$ for the Okhotsk Sea, $K=23-412$ for the Chukchi Sea, and $K=77$ for the East Siberian Sea. High enrichment for $\mathrm{Cu}$ (by 23 orders of magnitude) was revealed over water basins of all Far East seas $(K=13-351)$, for Cd over the Okhotsk ( $K=15-305)$ and Chukchi seas $(K=10-171)$, and for $\mathrm{Al}$ over the Okhotsk Sea $(K=42-328)$. We note that $\mathrm{Cu}$ and $\mathrm{Cd}$ mainly represent markers of anthropogenic emission; while $\mathrm{Al}$ is more indicative of terrigenous particle supply to the atmosphere. Maximal enrichment of aerosol by manganese was detected over the Okhotsk ( $K=194-217)$ and Chukchi $(K=20-198)$ seas. An elevated intensity of aerosol enrichment by iron was observed over the Japan $(K=13-34)$, Okhotsk $(K=9-40)$, and Chukchi $(K=1-80)$ seas.

An important role in determining the pollution level of atmospheric air is played by processes of trans-boundary transport of suspended particles and pollutants from adjoining territories. Far East seas are on the pathway of pollutant transport both from Eurasia and North America (see, e.g., Hov et al., 2007; Rudis, 2010; Vinogradova, 2014). In the contemporary period, pollutant outflows from China exert an ever-growing effect (Streets and Waldhof, 2000; Ohara et al., 2007). However, in this work we did not pursue the trajectory analysis of motion of air masses and the quantitative estimation of the effect some or other pollution sources have on samples collected in separate seas.

\subsection{Small gas-phase species}

Small gas-phase species and, especially, acid-forming gases, strongly influence the Earth's radiation budget, oxidizing or self-cleaning capacity of the atmosphere, aerosol formation, growth, and properties, and air quality. The average concentrations of gas-phase species $\left(\mathrm{HCl}, \mathrm{HNO}_{3}, \mathrm{SO}_{2}, \mathrm{NH}_{3}\right)$ in the study regions are presented in Table 8.

In the atmosphere of Far East seas, on average, the concentrations of acid-forming gases $\mathrm{HCl}, \mathrm{SO}_{2}$, and $\mathrm{HNO}_{3}$ decreased when going from warm (Okhotsk and Japan seas) to Arctic seas (East Siberian and Chukchi seas). Concentrations of $\mathrm{HCl}$ had decreased by approximately a factor of $4, \mathrm{SO}_{2}$ concentrations by a factor of 11 , and $\mathrm{HNO}_{3}$ concentrations from $0.45 \mu \mathrm{g} \mathrm{m}^{-3}$ to analytical zero, consistent with other research (Sun, 2002; Xu et al., 2005). The regularity of north- ward decrease in concentration largely showed up owing to data acquired on the forward route. This was also favored by meteorological conditions over the Chukchi Sea on 12 20 August (see Fig. 9d, e): high relative humidity, wind decline into a perfect calm, washing-out effect of precipitation, etc. On the return route, the $\mathrm{HCl}, \mathrm{SO}_{2}$, and $\mathrm{HNO}_{3}$ concentrations varied with latitude in different ways, with a lower level of mean concentrations being observed in mid-latitude seas. Seemingly, this divergence was due to different weather conditions and air mass types, as well as to smaller number of samples collected on the return route (e.g., only one sample was taken in the Japan Sea).

The $\mathrm{NH}_{3}$ concentrations were characterized by a relatively low and a very similar level - less than $0.1 \mu \mathrm{g} \mathrm{m}^{-3}$ on average, on the most part of the route of RV Professor Khljustin. The $\mathrm{NH}_{3}$ concentrations were only higher at polar latitudes on the return route, up to $0.21 \mu \mathrm{g} \mathrm{m}^{-3}$ over the Chukchi Sea.

Comparison with content of gas-phase species, obtained during preceding expeditions (Pol'kin and Golobokova, 2011) in the Japan Sea during spring 2009 and in the Okhotsk Sea during August 2010 allowed us to make the following conclusions. The average $\mathrm{HNO}_{3}$ concentrations are in best agreement with new data: they were $0.6 \mu \mathrm{g} \mathrm{m}^{-3}$ in 2009 and $0.66 \mu \mathrm{g} \mathrm{m}^{-3}$ in 2010. Average $\mathrm{HCl}$ concentrations, obtained earlier (1.7 and $4.3 \mu \mathrm{g} \mathrm{m}^{-3}$ ), are close to average data for return route of RV Professor Khljustin. Much larger $\mathrm{SO}_{2}$ and $\mathrm{NH}_{3}$ concentrations were observed in 2009 and 2010 expeditions. For instance, the average $\mathrm{SO}_{2}$ concentrations were 39.7 and $10.8 \mu \mathrm{g} \mathrm{m}^{-3}$ over the Japan and Okhotsk seas, respectively. The fact that the average concentrations of gas-phase species strongly differ between forward and return routes (see discussion above) and among diverse expeditions indicates that these abundances vary in wide range and depend strongly on direction of air transport. Despite their averaging over individual seas, the obtained compositions of the samples reflect the specific features of a particular period of measurements more, rather than peculiarities of the region of measurements.

With respect to content of gas-phase species, the atmosphere of the high-latitude region A (RV Akademik Fedorov) is somewhat different from Far East seas. The $\mathrm{HCl}$ concentrations in the high-latitude region are much lower and in good correspondence with latitudinal decrease of this gasphase species over Far East seas. The average $\mathrm{HNO}_{3}$ content turned out to be about the same as that over the Japan and Okhotsk seas. The $\mathrm{SO}_{2}$ and $\mathrm{NH}_{3}$ concentrations had been surprisingly high in the remote regions of the Arctic Ocean, though severalfold smaller than over the Japan and Okhotsk seas during 2009/2010 expeditions (Pol'kin and Golobokova, 2011). It is especially difficult to explain such a strong difference in gas-phase species content between region A and the East Siberian and Chukchi seas, which are close both in latitude and in climatic conditions.

In the absence of other data for Arctic region A, we performed a comparison with (a) measurements of gas-phase 
Table 8. Average concentrations of gas-phase species in the atmosphere $\left(\mu \mathrm{g} \mathrm{m}^{-3}\right)$ on the route of RV Akademik Fedorov and Professor Khljustin (the numerator indicates the total average in the region and standard deviations; the denominator indicates the average in the forward and return directions).

\begin{tabular}{lcccc}
\hline Area & $\mathrm{HCl}$ & $\mathrm{HNO}_{3}$ & $\mathrm{SO}_{2}$ & $\mathrm{NH}_{3}$ \\
\hline Arctic Ocean (A) & $0.91 \pm 0.46$ & $0.46 \pm 0.16$ & $4.31 \pm 2.55$ & $0.73 \pm 0.28$ \\
East Siberian Sea & $\frac{4.8 \pm 2.9}{2.7 / 6.8}$ & 0.00 & $\frac{0.06 \pm 0.00}{0.06 / 0.06}$ & $\frac{0.07 \pm 0.08}{0.01 / 0.13}$ \\
Chukchi Sea & $\frac{5.8 \pm 3.5}{6.3 / 4.6}$ & 0.00 & $\frac{0.13 \pm 0.14}{0.11 / 0.20}$ & $\frac{0.12 \pm 0.09}{0.09 / 0.21}$ \\
Bering Sea & $\frac{9.5 \pm 6.5}{15.7 / 4.8}$ & $\frac{0.11 \pm 0.19}{0.26 / 0.00}$ & $\frac{0.15 \pm 0.15}{0.26 / 0.07}$ & $\frac{0.04 \pm 0.02}{0.0330 .04}$ \\
Okhotsk Sea & $\frac{16.3 \pm 11.7}{24.7 / 3.6}$ & $\frac{0.40 \pm 0.36}{0.66 / 0.00}$ & $\frac{0.45 \pm 039}{0.70 / 0.09}$ & $\frac{0.04 \pm 0.02}{0.05 / 0.04}$ \\
Japan Sea & $\frac{20.9 \pm 12.4}{24.5 / 6.4}$ & $\frac{0.45 \pm 0.44}{0.56 / 0.01}$ & $\frac{0.66 \pm 037}{0.81 / 0.05}$ & $\frac{0.05 \pm 0.03}{0.05 / 0.03}$ \\
\hline
\end{tabular}

species in Ny-Ålesund at Svalbard during spring 2003 (Ianniello et al., 2007); (b) results of monitoring in mid-latitude background region of Lake Baikal (Golobokova et al., 2011). The gas-phase species concentrations in region A turned out to be even larger than maximal values in Ny-Ålesund: by a factor of 1.6 for $\mathrm{HNO}_{3}$ and by more than a factor of 6 for $\mathrm{HCl}$ and $\mathrm{SO}_{2}$. However, this comparison is not quite correct because of the difference in sampling techniques. It is more unambiguous to perform comparison with data for Lake Baikal, where the same methods and instruments were used for measurements. The average concentrations in the Lake Baikal during different periods of time vary from 0.6 to $4.8 \mu \mathrm{g} \mathrm{m}^{-3}$ for $\mathrm{SO}_{2}$, from 0 to $0.07 \mu \mathrm{g} \mathrm{m}^{-3}$ for $\mathrm{HNO}_{3}$, and are about $0.8 \mu \mathrm{g} \mathrm{m}^{-3}$ for $\mathrm{NH}_{3}$. That is, the average $\mathrm{SO}_{2}, \mathrm{HNO}_{3}$, and $\mathrm{NH}_{3}$ concentrations in region A are comparable with data in the background continental region.

This, of course, leaves the question as to why gas-phase species in region A have elevated content and needs confirmation (which is also true for other characteristics). We hope that measurements in a new Arctic expedition NABOS2015 (August-September 2015) along an analogous route will help to clarify the question.

In addition to individual analysis of content of gas-phase species, we also considered their joint variations with concentration of sum of ions. Interrelation between summed concentrations of gas-phase species and ions (with correlation coefficient of 0.68) manifested on the route of RV Akademik Fedorov. Over Far East seas (RV Professor Khljustin), the $\mathrm{SO}_{2}$ concentrations correlate well with the concentrations of methanesulfonic acid (correlation coefficient of 0.77), probably because dimethyl sulfide oxidizes to form $\mathrm{SO}_{2}$. Moreover, there was a weak negative correlation between concentrations of $\mathrm{NH}_{3}$ and sum of gases $\mathrm{HCl}, \mathrm{SO}_{2}$, and $\mathrm{HNO}_{3}$. These interrelations may indicate that chemical processes flow between these components. However, the available information is still insufficient to make firm conclusions.

\subsection{Deposition of chemical substances to sea surface}

The obtained results (see Tables 6-8) were used to estimate the vertical deposition of water-soluble substances to the sea surface. In the deposition calculations in the Arctic zone (region A; East Siberian, Chukchi, and Bering seas), we used the values, known from literature data: dry deposition velocity geometric mean, equaling $1.9 \times 10^{-3} \mathrm{~m} \mathrm{~s}^{-1}$ for the open sea (Nilsson et al., 2001); and deposition velocity of particles, equaling $2 \times 10^{-2} \mathrm{~m} \mathrm{~s}^{-1}$ for coastal regions (Duce et al., 1991; Shevchenko, 2006). Table 9 presents deposition calculations for two groups of marine water basins: Arctic seas and Far East seas at temperate latitudes.

The deposition of substances, coming from the atmosphere together with different ions (under heading "Ions" in Table 9), were determined for the sum of $\mathrm{Na}, \mathrm{K}, \mathrm{Mg}, \mathrm{Ca}, \mathrm{Cl}$, $\mathrm{N}$, and $\mathrm{S}$. Nitrogen was recalculated in the sum of nitrates and ammonium ions, and sulfur was recalculated from sulfates. Deposition of trace elements (TE) were calculated for the sum of $\mathrm{Al}, \mathrm{Ti}, \mathrm{V}, \mathrm{Cr}, \mathrm{Fe}, \mathrm{Co}, \mathrm{Ni}, \mathrm{Cu}, \mathrm{Zn}$, As, Se, Mo, Cd, Sb, $\mathrm{Pb}, \mathrm{Ba}, \mathrm{Be}, \mathrm{B}, \mathrm{Li}, \mathrm{Mn}$, and $\mathrm{Sr}$ concentrations. In the calculation of substances, supplied together with gas-phase species (GI), we took the sum of the $\mathrm{Cl}, \mathrm{N}$, and $\mathrm{S}$ concentrations, calculated from gaseous species $\mathrm{HCl}, \mathrm{HNO}_{3}, \mathrm{NH}_{3}$, and $\mathrm{SO}_{2}$ respectively. In the calculations, we used the maximal deposition velocities of gases over water surface for each of the gasphase species: $2.6 \times 10^{-2} \mathrm{~m} \mathrm{~s}^{-1}$ for $\mathrm{HNO}_{3}, 2.2 \times 10^{-2} \mathrm{~m} \mathrm{~s}^{-1}$ for $\mathrm{NH}_{3}, 2.1 \times 10^{-2} \mathrm{~m} \mathrm{~s}^{-1}$ for $\mathrm{SO}_{2}$ (Zhang et al., 2003), and $1.3 \times 10^{-2} \mathrm{~m} \mathrm{~s}^{-1}$ for $\mathrm{HCl}$ (Clark et al., 1984).

Use in the calculations of particle deposition velocities, differing by an order of magnitude $\left(1.9 \times 10^{-3}\right.$ and $2 \times$ $10^{-2} \mathrm{~m} \mathrm{~s}^{-1}$ ), naturally translates to a difference in deposition of an order of magnitude. In this regard, when comparing the vertical deposition of substances, supplied together with aerosol substance and gas-phase species, we will use, as was conventional in a number of research studies (Duce et al., 1991; Shevchenko, 2006), the aerosol particle deposition velocity of $2 \times 10^{-2} \mathrm{~m} \mathrm{~s}^{-1}$. From these data it follows that, both in Arctic and Far East seas, a maximal amount of substance is supplied to the surface together with gas-phase 
Table 9. Diurnally average vertical fluxes of water-soluble substances together with aerosol and gas-phase species $\left(\mathrm{mg} \mathrm{m}^{-2} \mathrm{day}^{-1}\right)$ according to data of measurements in Arctic and Far East seas (RV Akademik Fedorov and RV Professor Khljustin).

\begin{tabular}{|c|c|c|c|c|c|}
\hline \multirow[t]{3}{*}{ Area } & \multicolumn{4}{|c|}{ Deposition velocity } & \multirow[b]{3}{*}{ GI } \\
\hline & \multicolumn{2}{|c|}{$1.9 \times 10^{-3} \mathrm{~ms}^{-1}$} & \multicolumn{2}{|c|}{$2.0 \times 10^{-2} \mathrm{~m} \mathrm{~s}^{-1}$} & \\
\hline & Ions & TE & Ions & TE & \\
\hline \multicolumn{6}{|l|}{ Arctic seas } \\
\hline Arctic Ocean (region A) & 0.21 & 0.003 & 2.17 & 0.034 & 6.28 \\
\hline East Siberian Sea & 0.17 & 0.003 & 1.75 & 0.030 & 5.41 \\
\hline Chukchi Sea & 0.28 & 0.005 & 2.94 & 0.056 & 6.64 \\
\hline \multicolumn{6}{|c|}{ Far East seas (mid-latitudes) } \\
\hline Bering Sea & - & - & 4.14 & 0.043 & 10.64 \\
\hline Okhotsk Sea & - & - & 5.68 & 0.093 & 18.48 \\
\hline Japan Sea & - & - & 4.59 & 0.104 & 23.74 \\
\hline
\end{tabular}

species. On average, deposited ions accounted for about $24.7 \%$, trace elements accounted for $0.4 \%$, and small gasphase species accounted for $74.9 \%$ of the total amount of substances (Ions + TE + GI), coming from the atmosphere. The maximal deposition of substances together with ions was observed in the areas of the Chukchi and Bering seas (28 and 30\%), and minimal deposition was observed over the Japan Sea (16\%). Among the ions, maximal contribution (66-83\%) to substance deposition comes from maritime component, i.e., $\mathrm{Na}$ and $\mathrm{Cl}$. Depositions of substances, supplied together with ions to the surface of the Arctic seas, are quite close to analogous data from the monitoring station Primorskaya (2.11 $\mathrm{mg} \mathrm{m}^{-2} \mathrm{day}^{-1}$ ) (EANET, 2011).

A different relationship is observed in the distribution of depositions of gas-phase species in these regions. Over the Arctic Ocean (region A), $\mathrm{HCl}$ accounts for about $16 \%$, the sum $\left(\mathrm{NH}_{3}+\mathrm{HNO}_{3}\right)$ accounts for about $22 \%$, and $\mathrm{SO}_{2}$ accounts for $62 \%$. Over Far East seas, the main contribution (up to $97 \%$ ) to the substance deposition is due to $\mathrm{Cl}$.

In the total sum (Ions $+\mathrm{TE}+\mathrm{GI}$ ), the average substance depositions over the Japan and Okhotsk seas are 3 times larger than over Arctic seas. As was already noted in Sect. 5.1-5.3, these regions experience a strong effect of continental sources of aerosol and gases. The substance depositions over the Bering Sea occupy an intermediate position between Arctic seas and more southern seas.

For comparison purposes, we present estimates (Shevchenko, 2006), according to which the average vertical aerosol deposition in the Arctic is about $600 \mathrm{mg} \mathrm{m}^{-2}$ year $^{-1}$ (or $1.64 \mathrm{mg} \mathrm{m}^{-2} \mathrm{day}^{-1}$ ) and incorporates salt, terrigenous, and organic parts. The elemental composition of insoluble fraction is reported by the author to be, on average, $0.39 \mathrm{mg} \mathrm{m}^{-2}$ day $^{-1}$, i.e., $1 / 4$ part. Hence, the remaining part $\left(1.25 \mathrm{mg} \mathrm{m}^{-2} \mathrm{day}^{-1}\right)$ is accounted for by salt and organic parts of aerosol. According to our estimates (see Table 9), soluble-part depositions alone (Ions $+\mathrm{TE}$ ) are
$2.2 \mathrm{mg} \mathrm{m}^{-2}$ day $^{-1}$, almost a factor of 2 larger. The discrepancy seems to be because the method for deposition estimation (Shevchenko, 2006) used a number of model assumptions. Our calculations are based on real measurements, but they characterize just a separate period and region of measurements; therefore, they may differ from average depositions for the entire Arctic.

We considered separately the vertical depositions of sulfur and nitrogen, deposited together with aerosol substances $\left(S_{\text {aer }}, N_{\text {aer }}\right)$ and gas-phase species $\left(S_{\text {gas }}, N_{\text {gas }}\right)$ (see Table 10$)$. A tendency for deposition intensity to decrease from south to north is apparent in the delivery of sulfur together with aerosol substance $\left(S_{\mathrm{aer}}\right)$. Other components of sulfur and nitrogen depositions $\left(N_{\text {aer }}, S_{\text {gas }}, N_{\text {gas }}\right)$ keep latitudinal decrease in north direction only as far as East Siberian Sea, and over the Arctic Ocean (A) they sharply increase (by more than an order of magnitude). This jump is a consequence of anomalously high $\mathrm{NH}_{4}^{+}, \mathrm{SO}_{2}$, and $\mathrm{NH}_{3}$ concentrations (see Sect. 5.1 and 5.3) in the high-latitudes of region A, which are not explained yet.

Using available literature data, we performed a comparison with vertical sulfur and nitrogen depositions in the northeastern part of the Atlantic Ocean near Bermuda (Sievering et al., 1989) and with data from continental region, i.e., from Primorskaya monitoring station (EANET, 2011). The comparison showed that the deposition of the summed sulfur $\left(S_{\text {aer }}+S_{\text {gas }}\right)$ in the area of Bermuda $\left(0.43-0.52 \mathrm{mg} \mathrm{m}^{-2}\right.$ day $\left.^{-1}\right)$ satisfactorily agrees with our data for Bering and Okhotsk seas. The average intensities of deposition of sulfur $\left(0.68 \mathrm{mg} \mathrm{m}^{-2} \mathrm{day}^{-1}\right)$ and nitrogen $\left(0.37 \mathrm{mg} \mathrm{m}^{-2} \mathrm{day}^{-1}\right)$ at Primorskaya station are close to our data for Far East seas at mid-latitudes.

The intensity of nitrogen deposition in soluble aerosol fraction $\left(N_{\text {aer }}\right)$ was compared with data, obtained by Jung et al. (2013) in the subarctic western North Pacific Ocean $\left(0.25 \mathrm{mg} \mathrm{m}^{-2} \mathrm{day}^{-1}\right)$. This value is comparable with $N_{\text {aer }}$ de- 
Table 10. Diurnally average vertical fluxes of sulfur and nitrogen together with aerosol and gas-phase species $\left(\mathrm{mg} \mathrm{m}^{-2} \mathrm{day}^{-1}\right)$ according to data of measurements in Arctic and Far East seas (RV Akademik Fedorov and Professor Khljustin).

\begin{tabular}{lrrrrrr}
\hline Area & $\begin{array}{r}S_{\text {aer }} \\
\left(\mathrm{SO}_{4}^{2-}\right)\end{array}$ & $\begin{array}{r}N_{\text {aer }} \\
\left(\mathrm{NH}_{4}^{+}+\mathrm{NO}_{3}^{-}\right)\end{array}$ & $\begin{array}{r}S_{\text {gas }} \\
\left(\mathrm{SO}_{2}\right)\end{array}$ & $\begin{array}{r}N_{\text {gas }} \\
\left(\mathrm{NH}_{3}+\mathrm{HNO}_{3}\right)\end{array}$ & $S_{\text {aer }}+S_{\text {gas }}$ & $N_{\text {aer }}+N_{\text {gas }}$ \\
\hline Arctic seas & & & & & & \\
\hline Arctic Ocean (region A) & 0.06 & 0.19 & 3.91 & 1.37 & 3.97 & 1.56 \\
East Siberian Sea & 0.04 & 0.00 & 0.05 & 0.11 & 0.09 & 0.11 \\
Chukchi Sea & 0.14 & 0.002 & 0.12 & 0.19 & 0.26 & 0.192 \\
\hline Far East seas (mid-latitudes) & & & & & & 0.15 \\
\hline Bering Sea & 0.48 & 0.03 & 0.14 & 0.12 & 0.62 & 0.28 \\
Okhotsk Sea & 0.24 & 0.02 & 0.41 & 0.26 & 0.65 & 0.41 \\
Japan Sea & 0.33 & 0.11 & 0.60 & 0.30 & 0.99 & 0.15 \\
\hline
\end{tabular}

position in the high-latitude Arctic (region A), but is severalfold larger than over Far East seas.

We conclude by noting once again that these results rely on a small number of samples collected for separate regions, and reflect the chemical composition of the aerosol atmosphere in specific periods of measurements. Therefore, these characteristics are estimative in character and need a confirmation and further interpretation.

\section{Conclusions}

In summer 2013, we carried out the integrated studies of the atmospheric aerosol in two cruises of RV Akademik Fedorov and RV Professor Khljustin, the routes of which covered the most part of the Northern Sea Route from the Barents to Japan Sea. The data obtained were used to analyze the optical and microphysical characteristics and chemical composition of aerosol of the Arctic Ocean and Far East seas. It should be noted that the results and regularities, discussed here, are estimative in character because of high spatiotemporal variations of atmospheric aerosol for relatively short periods of observations in separate regions. Like in other marine expeditions, the aerosol characteristics were determined by the specific features of hydrometeorological conditions in measurement periods, to some or another degree. At the same time, we underline the importance of acquiring the new information on specific features of physical-chemical aerosol composition in hard-to-reach and poorly studied regions of the planet.

The studies performed make it possible to draw the following main conclusions.

a. The atmospheric AOD in Siberian sector of Arctic and in the subpolar Bering Sea was characterized by small and nearly identical values: the average AOD values at the wavelength of $0.5 \mu \mathrm{m}$ were 0.03 ; in particular, the finely dispersed component was 0.021 , and the coarsely dispersed component was 0.009 . For a comparison, we note that AOD values over Arctic seas turned out to be 5 times smaller than in background mid-latitude regions, and a factor of 1.5-2 smaller than in the region of Spitsbergen in this same time period. The growth in the southern direction is manifested in the spatial distribution of aerosol turbidity of the atmosphere over Far East seas. The AOD characteristics over the Bering Sea are almost the same as in Arctic; and AOD over the Japan Sea increases by more than a factor of 5 in the visible spectral range and by up to a factor of 3 in IR range.

b. The average boundary layer height $\left(H_{\mathrm{BL}}\right)$, measured by ship-based lidar on the RV Professor Khljustin cruise, was $520 \mathrm{~m}$; and the maximal boundary layer height (near the Arctic port of Pevek) was $1200 \mathrm{~m}$. In the latitudinal distribution, the height $H_{\mathrm{BL}}$ first decreased, and then increased northward of $55^{\circ} \mathrm{N}$. The elevated values of the height $H_{\mathrm{BL}}$ at subarctic latitudes seem to be due to increased effect of continent (Chukchi Peninsula) and predominating winds from the direction of the land. (The $H_{\mathrm{BL}}$ values are generally lower when air masses are carried from the direction of the ocean.)

c. The local measurements of disperse composition of aerosol and concentration of black carbon in the nearground layer showed their high variability even in the clean atmosphere of Arctic. Nonetheless, on average, the aerosol and black carbon contents can be traced to decrease in the northeastern direction along the route of RV Akademik Fedorov. The largest average concentrations were observed in the southern part of the Barents Sea: $N_{\mathrm{A}}=6.5 \mathrm{~cm}^{-3} ; M_{\mathrm{A}}=1290 \mathrm{ng} \mathrm{m}^{-3}$; and $M_{\mathrm{BC}}=$ $140 \mathrm{ng} \mathrm{m}^{-3}$. As the separation from the Kola Peninsula grew, the aerosol number and mass concentrations decreased on average by $10-30 \%$, down to $N_{\mathrm{A}}=2.5-$ $5.7 \mathrm{~cm}^{-3}$ and $M_{\mathrm{A}}=830-930 \mathrm{ng} \mathrm{m}^{-3}$. The differences in aerosol concentrations over other regions of the Arctic Ocean were mainly determined by the specific character of hydrometeorological conditions, and not by 
the degree of separation from the continent. A stronger and longer-term decrease (with increasing distance from Scandinavian Peninsula) was found for the mass concentration of black carbon. The average $M_{\mathrm{BC}}$ value decreased by a factor of $\sim 6$ down to $22 \mathrm{ng} \mathrm{m}^{-3}$ in the northern part of the route (region A).

d. As expected, the range of the spatiotemporal variations in aerosol and black carbon concentrations along the Far East route of RV Professor Khljustin $\left(42-71^{\circ} \mathrm{N}\right)$ turned out to be much wider: $N_{\mathrm{A}}$ varied from 0.003 to $90.2 \mathrm{~cm}^{-3} ; M_{\mathrm{A}}$ varied from 1 to $13630 \mathrm{ng} \mathrm{m}^{-3}$; and $M_{\mathrm{BC}}$ varied from 2 to $400 \mathrm{ng} \mathrm{m}^{-3}$. The averaging of aerosol parameters within four latitude zones, corresponding to separate seas, made it possible to identify the tendency toward their latitudinal decrease from south to north. The aerosol number concentration decreased from $23.7 \mathrm{~cm}^{-3}$ over the Japan Sea to $2.5 \mathrm{~cm}^{-3}$ over the Chukchi Sea (by about a factor of 9), the black carbon mass concentration decreased from 150 to $50 \mathrm{ng} \mathrm{m}^{-3}$ (by about a factor 3 ), and the aerosol mass concentration decreased by almost a factor of 4 .

The obtained results indicate that the number concentrations of fine and coarse aerosols show opposite latitudinal variations; as a consequence, the relative contribution of coarsely dispersed fraction in the Arctic zone increased by a factor of 4.5. This was favored not only by weakening of outflows of small-sized continental aerosol, but also by increase in generation of large-sized maritime aerosol under the influence of strong wind and sea roughness at high latitudes. It is shown that with respect to relative contents of two aerosol fractions, we can quite distinctly single out two zones: mid-latitudes (southward of $64^{\circ} \mathrm{N}$ ), where fine aerosol predominates and the mean ratio $\left(N_{\mathrm{c}} / N_{\mathrm{f}}\right)=10^{-2}$; and Arctic latitudes, where the role of large particles increases and the ratio $\left(N_{\mathrm{c}} / N_{\mathrm{f}}\right)$ grows to $4.5 \times 10^{-2}$.

Based on analysis of aerosol number concentrations and meteorological parameters for the entire period of measurements, we obtained regression model (Eq. 5), which reflects the linear dependence of $N_{\mathrm{A}}$ on wind speed, air temperature, and rainfall amount. Good agreement between the actual and model-calculated $N_{\mathrm{A}}$ values is observed in the following range of meteorological conditions: wind speed $0.5<\mathrm{WS}<10 \mathrm{~m} \mathrm{~s}^{-1}$, air temperature $-2.5<T<16^{\circ} \mathrm{C}$, and rainfall $0<\mathrm{RF}<44 \mathrm{~mm} \mathrm{~h}^{-1}$.

e. Based on results of the chemical analysis of samples, collected in cruises of RV Akademik Fedorov and Professor Khljustin, we determined the average contents of ions and water-soluble elements in aerosol. The sodium ions and chloride ions predominated in aerosol composition throughout the route. Data averaging over three larger water basins (the Arctic Ocean and northern and southern Far East seas) showed that the average concen- trations of most ions increase in the southern direction. As a result, the summed concentration of ions, as compared to the Arctic Ocean, increased by $73 \%$ over the Bering and Chukchi seas and by a factor of 2.5 at midlatitudes.

The concentrations of water-soluble elements in aerosol composition varied from several tens to several thousandths. Despite certain differences, the concentrations of elements over the Arctic Ocean and Far East seas are grouped in the same way. Members in the first highconcentration group are metals: $\mathrm{Zn}, \mathrm{Cu}, \mathrm{Al}, \mathrm{Fe}, \mathrm{Ba}, \mathrm{Mn}$, and Sr. Their percentage was $93.7 \%$ of the sum of all microelements in region A and $94.4 \%$ over Far East seas. The second group included $\mathrm{Ni}, \mathrm{Cd}, \mathrm{Cr}, \mathrm{Se}, \mathrm{Pb}$, and $\mathrm{V}$ (5.4 and $5.2 \%$ of the total composition). The third group was represented by $\mathrm{Mo}, \mathrm{Ti}, \mathrm{Co}, \mathrm{Sb}, \mathrm{Li}, \mathrm{As}$, and $\mathrm{Be}(0.9$ and $0.3 \%$ of the total composition). The average percentage of elements in the total sum of soluble components increases in the southern direction from $1.4 \%$ in region A to $1.9 \%$ in the Japan Sea (except in the Bering Sea, where the average percentage of elements had been $0.8 \%$ ). With respect to intensity of enrichment of aerosol particles by the elements $\mathrm{Zn}, \mathrm{Cu}, \mathrm{Al}, \mathrm{Fe}, \mathrm{Mn}$, $\mathrm{Cr}$, and $\mathrm{Cd}$, the study regions can be lined up in the following order: Okhotsk Sea, Arctic Ocean, Chukchi Sea, Japan Sea, Bering Sea, and East Siberian Sea.

We determined the average content of small gas-phase species $\left(\mathrm{HCl}, \mathrm{HNO}_{3}, \mathrm{SO}_{2}, \mathrm{NH}_{3}\right)$ in the atmosphere for separate seas on the Northern Sea Route. From comparison with data of cruises of RV Akademik Fedorov and Professor Khljustin it follows that the concentration of gaseous $\mathrm{HCl}$ is severalfold higher, and the concentrations of $\mathrm{SO}_{2}$ and $\mathrm{NH}_{3}$ are severalfold lower, over Far East seas. Analysis of variations in the content of small gas-phase species and variations in the sum of ions over the Arctic Ocean showed the presence of their interrelation with the correlation coefficient of 0.68 . The variations in the $\mathrm{SO}_{2}$ and methanesulfonic acid (MSA) concentrations over Far East seas are found to be closely interrelated, with a correlation coefficient of 0.77 , possibly indicating that dimethyl sulfide (DMS) was oxidized to give $\mathrm{SO}_{2}$.

The vertical depositions of water-soluble substances to marine surface are estimated. On average, deposited ions accounted for about $24.7 \%$, trace elements accounted for $0.4 \%$, and small gas-phase species accounted for $74.9 \%$ of the total amount of substances (Ions $+\mathrm{TE}+\mathrm{GI}$ ), coming from the atmosphere. The maximal depositions of substances together with ions were observed in the areas of the Chukchi and Bering seas (28 and $30 \%$ ), and minimal depositions were observed over the Japan Sea (16\%). The largest contribution $(66-83 \%)$ to the deposition of substances was made by the maritime component, i.e., $\mathrm{Na}$ and $\mathrm{Cl}$. 
Among the gaseous species in the Arctic Ocean (region $\mathrm{A}$ ), chlorine $(\mathrm{HCl})$ accounts for about $16 \%$, nitrogen $\left(\mathrm{NH}_{3}+\mathrm{HNO}_{3}\right)$ accounts for about $22 \%$, and sulfur $\left(\mathrm{SO}_{2}\right)$ accounts for $62 \%$. Over Far East seas, up to $97 \%$ of deposition of substances were accounted for by $\mathrm{Cl}$.

Acknowledgements. Authors thank the crews of RV Akademik Fedorov and Professor Khljustin for assistance and support in the expedition studies. For an opportunity to incorporate additional information, which was used in our publication, we also gratefully acknowledge scientific organizations such as:

- Tiksi meteorological observatory and GSFC/NASA for data of AERONET observations in the region of Tiksi;

- NOAA Air Resources Laboratory (ARL) for the possibility of using the HYSPLIT transport model (ECMWF Interim data);

- NASA/LaRC Science Data Center and the CALIPSO Search and Subsetting web application (https://www-calipso.larc. nasa.gov) for providing access to the CALIPSO data;

- IACP FEB RAS Multiple Access Center "Laser methods of investigating condensed media and biological objects and environmental monitoring" for providing access to experimental facilities.

This work was supported by the Program of Basic Research of Presidium of the Russian Academy of Sciences no. 23 and projects of partnership basic research of the Siberian Branch of the Russian Academy of Sciences no. 25. The planetary boundary layer studies were supported by the Russian Science Foundation (Project No. 14-50-00034). The studies of variations of aerosol microphysical properties throughout the eastern Pacific were also supported by the Russian Science Foundation (Project No. 14-19-00589).

Edited by: J. G. Murphy

\section{References}

Albrecht, B.: Aerosols, cloud microphysics, and fractional cloudiness, Science, 245, 1227-1230, 1989.

Alekseev, G. V., Ivanov, N. E., Pnyushkov, A. V., and Kharlanenkova, N. E.: Climate change in the marine Arctic in the beginning of 21st century, in: Meteorological and Geophysical Researches, edited by: Alekseev, G. V., Paulsen, Moscow, Saint Petersburg, Russia, 352 pp., 2011 (in Russian).

Andreas, E. L.: A new Sea Spray Generation Function for Wind Speeds up to $32 \mathrm{~m} \mathrm{~s}^{-1}$, J. Phys. Oceanogr., 28, 2175-2184, 1998.

Andreev, S. Y., Afonin, S. V., Bedareva, T. V., Beresnev, S. A., Bukin, O. A., Golobokova, L. P., Gorbarenko, E. V., Gorda, S. Y., Gribanov, K. G., Eremina, T. A., Zhamsueva, G. S., Zhuravleva, T. B., Zakharov, V. I., Zayakhanov, A. S., Kabanov, D. M., Kozlov, V. S., Kornienko, G. I., Lomakina, N. Y., Luzhetskaya, A. P., Maior, A. Y., Markelov, Y. I., Nagovitsyna, E. S., Naguslaev, S. A., Nasrtdinov, I. M., Netsvetaeva, O. G., Nikolashkin S. V., Obolkin, V. A., Onishchuk, N. A., Pavlov, A. N., Panchenko, M. V., Poddubnyi, V. A., Pol'kin, V. V., Potemkin, V. L., Rasskazchikova, T. M., Rokotyan, N. V., Rostov, A. P.,
Sakerin, S. M., Salyuk, P. A., Smirnov, A. V., Sklyadneva, T. K., Stolyarchuk, S. Y., Tashchilin, M. A., Terpugova, S. A., Turchinovich, S. A., Turchinovich, Y. S., Filippova, U. G., Khodzher, T. V., Holben, B. N., Tsydypov, V. V., Chesnokova, T. Y., Shmargunov, V. P., Shmirko, K. A., and Engel, M. V.: Study of radiative characteristics of aerosol in Asian part of Russia, edited by: Sakerin, S. M., Publishing House of Institute of Atmospheric Optics SB RAS, Tomsk, Russia, 484 pp., 2012 (in Russian).

Balin, Y. S., Ershov, A. D., and Penner, I. E.: Shipborne lidar investigations of aerosol fields in the atmosphere over Lake Baikal Part 1: Longitudinal sections, Atmos. Ocean. Opt., 16, 402-410, 2003 (in Russian).

Bigg, E. K., Grass, J. L., and Mossop, D. J. C.: Wind-produced submicron particles in the marine atmosphere, Atmos. Res., 36, 5568, 1995

Boé, J., Hall, A., and Qu, X.: Current GCMs' unrealistic negative feedback in the arctic, J. Climate, 22, 4682-4695, 2009.

Bradley, R. S. and Keimig, F. T.: Recent changes in the North American Arctic boundary layer in winter, J. Geophys. Res., 98, 88518858, 1993.

Bukin, O. A., Pavlov, A. N., Saluk, P. A., Kulchin, Y. N., Shmirko, K. A., Stolyarchuk, S. Y., and Bubnovskii, A. Y.: Peculiarities of the aerosol vertical distribution during the passage of dust storms over the Peter the Great Bay in 2006 and their influence on phytoplankton communities in the Japan Sea, Atmos. Ocean. Opt., 20, 306-312, 2007.

Bukin, O. A., Kulchin, Y. N., Pavlov, A. N., Stolyarchuk, S. Y., and Shmirko, K. A.: Characteristics of structure and dynamics of the planetary boundary layer in the transitional "oceancontinent” zone-Part 1: Winter period, Atmos. Ocean. Opt., 26, 60-67, 2013.

Chubarova, N., Nezval', Ye., Sviridenkov, I., Smirnov, A., and Slutsker, I.: Smoke aerosol and its radiative effects during extreme fire event over Central Russia in summer 2010, Atmos. Meas. Tech., 5, 557-568, doi:10.5194/amt-5-557-2012, 2012.

Clark, P. A., Fletcher, I. S., Kallend, A. S., McElroy, W. J., Marsh, A. R. W., and Webb, A. H.: Observations of cloud chemistry during longrange transport of power plant plumes, Atmos. Environ., 18, 1849-1858, 1984.

Deser, C., Tomas, R., Alexander, M., and Lawrence, D.: The seasonal atmospheric response to projected Arctic sea ice loss in the late twenty-first century, J. Climate, 23, 333-351, 2010.

Domine, F., Sparapani, R., Ianniello, A., and Beine, H. J.: The origin of sea salt in snow on Arctic sea ice and in coastal regions, Atmos. Chem. Phys., 4, 2259-2271, doi:10.5194/acp-4-2259-2004, 2004.

Duce, R. A., Liss, P. S., Merrill, J. T., Atlas, E. L., Buat-Menard, P., Hicks, B. M., Miller, B. J., Prospero, R., Arimoto, J. M., Church, T. M., Ellis, W., Galloway, J. N., Hansen, L., Jickells, T. D., Knap, A. H., Reinhardt, K. H., Schneider, B., Soudine, A. J., Tokos, J., Tsunogai, S., Wollast, R., and Zhou, M.: The atmospheric input of trace species to the world ocean, Global Biogeochem. Cy., 5, 193-259, 1991.

Dutkiewicz, V. A., DeJulio, A. M., Ahmed, T., Laing, J., Hopke, P. K., Skeie, R. B., Viisanen, Y., Paatero, J., and Husain, L.: Forty-seven years of weekly atmospheric black carbon measurements in the Finnish Arctic: Decrease in black carbon with declining emissions, J. Geophys. Res.-Atmos., 119, 7667-7683, doi:10.1002/2014JD021790, 2014. 
EANET: Second Periodic Report on the State of Acid Deposition in East Asia. Part II: National Assessments, Niigata, Japan: Acid Deposition Monitoring Network in East Asia (EANET), 305 pp., 2011.

Eck, T. F., Holben, B. N., Reid, J. S., Sinyuk, A., Hyer, E. J., O’Neill, N. T., Shaw, G. E., Vande Castle, J. R., Chapin, F. S., Dubovik, O., Smirnov, A., Vermote, E., Schafer, J. S., Giles, D., Slutsker, I., Sorokine, M., and Newcomb, W. W.: Optical properties of boreal region biomassburning aerosols in central Alaska and seasonal variation of aerosol optical depth at an Arctic coastal site, J. Geophys. Res., 114, D11201, doi:10.1029/2008JD010870, 2009.

Eisenman, I., Untersteiner, N., and Wettlaufer, J. S.: On the reliability of simulated Arctic sea ice in global climate models, Geophys. Res. Lett., 34, L10501, doi:10.1029/2007GL029914, 2007.

Eleftheriadis, K. Vratolis S., and Nyeki, S.: Aerosol black carbon in the European Arctic: Measurements at Zeppelin Station, NyÅlesund, Svalbard from 1998-2007, Geophys. Res. Lett., 36, L02809, doi:10.1029/2008GL035741, 2009.

EMEP: Manual for sampling and chemical analysis, Norwegian Institute for Air Research, EMEP/CCC-Report 1/95, O-7726, 176 pp., 1996.

Golobokova, L. P., Filippova, U. G., Marinaite, I. I., Belozerova, O. Yu., Gorshkov, A. G., Obolkin, V. A., Potemkin, V. L., and Khodzher, T. V.: Chemical composition of atmospheric aerosol above the Lake Baikal area, Atmos. Ocean. Opt., 24, 236-241, 2011 (in Russian).

Golobokova, L. P., Polkin, V. V., Kabanov, D. M., Khodzher, T. V., Terpugova, S. A., Chernov, D. G., Chipanina, E. V., Panchenko, M. V., and Sakerin, S. M.: Studies of atmospheric aerosol in the Arctic regions of Russia, Journal Ice and Snow/Led i Sneg, 122, 129-136, 2013 (in Russian).

Gorchakov, G. I., Sitnov, S. A., Sviridenkov, M. A., Semoutnikova, E. G., Emilenko, A. S., Isakov, A. A., Kopeikin, V. M., Karpov, A. V., Gorchakova, I. A., Verichev, K. S., Kurbatov, G. A., and Ponomareva, T. Ya.: Satellite and ground-based monitoring of smoke in the atmosphere during the summer wildfires in European Russia in 2010 and Siberia in 2012, Int. J. Remote Sens., 35, 5698-5721, 2014.

Goryunova, N. V. and Shevchenko, V. P.: Study of aerosols and particulate matter in snow on drifting ice in the western part of the Russian Arctic in August-September 2006, Problems of the Arctic and Antarctic/Problemy Arktiki i Antarktiti, 78, 112-117, 2008 (in Russian).

Grimm, H. and Eatough, D. J.: Aerosol measurement: the use of optical light scattering for the determination of particulate size distribution, and particulate mass, including the semi-volatile fraction, J. Air Waste Manage., 59, 101-107, 2009.

Hansen, A. D. A., Polissar, A. V., and Schnell, R. C.: Airborne aerosol and black carbon measurements over the East Siberian Sea, spring 1992, Atmos. Res., 44, 153-165, 1997.

Hara, K., Osada, K., Yabuki, M., and Yamanouchi, T.: Seasonal variation of fractionated sea-salt particles on the Antarctic coast, Geophys. Res. Lett., 39, L18801, doi:10.1029/2012GL052761, 2012.

Haywood, J. and Boucher, O.: Estimates of the direct and indirect radiative forcing due to tropospheric aerosols: a review, Rev. Geophys., 38, 513-543, 2000.
Hennemuth, B. and Lammert, A.: Determination of the atmospheric boundary layer height from radiosonde and lidar backscatter, Bound.-Lay. Meteorol., 120, 181-200, 2006.

Herber, A., Thomason, L. W., Gernandt, H., Leiterer, U., Nagel, D., Schulz, K., Kaptur, J., Albrecht, T., and Notholt, J.: Continuous day and night aerosol optical depth observations in the Arctic between 1991 and 1999, J. Geophys. Res., 107, 4097, doi:10.1029/2001JD000536, 2002.

Holben, B. N., Eck, T. F., Slutsker, I., Tanre, D., Buis, J. P., Setzer, A., Vermote, E., Reagan, J. A., Kaufman, Y. J., Nakadjima, T., Lavenu, F., Jankowiak, I., and Smirnov, A.: AERONET - a federated instrument network and data archive for aerosol characterization, Remote Sens. Environ., 66, 1-16, 1998.

Hov, Ø., Shepson, P. B., and Wolff, E. W.: The chemical composition of the polar atmosphere - the IPY contribution, WMO Bull., 56, 263-270, 2007.

Huang, L., Gong, S. L., Sharma, S., Lavoué, D., and Jia, C. Q.: A trajectory analysis of atmospheric transport of black carbon aerosols to Canadian high Arctic in winter and spring (19902005), Atmos. Chem. Phys., 10, 5065-5073, doi:10.5194/acp10-5065-2010, 2010.

Ianniello, A., Beine, H. J., Landis, M. S., Stevens, R. K., Esposito, G., Amoroso, A., and Allegrini, I.: Comparing field performances of denuder techniques in the high Arctic, Atmos. Environ., 41, 1604-1615, 2007.

ICS-3000 Ion: Chromatography System Operator's Manual, Dionex Corporation, Document No. 065031, 392 pp., 2008.

IPCC: Climate Change 2007: Synthesis Report, Intergovernmental Panel on Climate Change, 52 pp., available at: http:// www.ipcc.ch/pdf/assessment-report/ar4/syr/ar4_syr.pdf (last access: May 2012), 2007.

IPCC: Climate Change 2013: The Physical Science Basis, Intergovernmental Panel on Climate Change, 1552 pp., available at: http://www.climatechange2013.org/images/report/ WG1AR5_ALL_FINAL.pdf (last access: August 2014), 2013.

Johnson, B., Shine, K., and Forster, P.: The semi-direct aerosol effect: impact of absorping aerosols on marine stratocumulus, Q. J. Roy. Meteor. Soc., 130, 1407-1422, 2004.

Jung, J., Furutani, H., Uematsu, M., Kim, S., and Yoon, S.: Atmospheric inorganic nitrogen input via dry, wet, and sea fog deposition to the subarctic western North Pacific Ocean, Atmos. Chem. Phys., 13, 411-428, doi:10.5194/acp-13-411-2013, 2013.

Kabanov, D. M., Veretennikov, V. V., Voronina, Y. V., Sakerin, S. M., and Turchinovich, Y. S.: Information system for network sunphotometers, Atmos. Ocean. Opt., 22, 121-127, doi:10.1134/S1024856009010187, 2009.

Kay, J. E., Raeder, K., Gettelman, A., and Anderson, J.: The boundary layer response to recent arctic sea ice loss and implications for high-latitude climate feedbacks, J. Climate, 24, 428-447, 2011.

Kondratyev, K. Y.: Aerosol as a climate-forming component of the atmosphere. 2. Direct and indirect impact on climate, Atmos. Ocean. Opt., 15, 267-284, 2002.

Kondratyev, K. Y.: Aerosol and climate studies: current state and prospects. 3. Aerosol radiative forcing, Atmos. Ocean. Opt., 19, 505-513, 2006.

Kopeikin, V. M., Repina, I. A., Grechko, E. I., and Ogorodnikov, B. I.: Measurements of the soot aerosol content in the near-water 
layer in Southern and Northern Hemispheres, Atmos. Ocean. Opt., 23, 444-450, 2010 (in Russian).

Kozlov, V. S., Shmargunov, V. P., and Polkin, V. V.: Spectrometers to study the properties of light absorption by aerosol particles, Instrum. Exp. Tech., 5, 155-157, 2008 (in Russian).

Kozlov, V. S., Polkin, V. V., Panchenko, M. V., Golobokova, L. P., Turchinovich Y. S., and Khodzher, T. V.: Results of integrated aerosol experiment in the continent-ocean transition zone (Primorye and the Sea of Japan). Part 3. Microphysical characteristics and ion compo-sition of aerosol in the near-ground and near-water layers, Atmos. Ocean. Opt., 23, 967-977, 2010 (in Russian).

Kozlov, V. S., Yausheva, E. P., Terpugova, S. A., Panchenko, M. V., Chernov, D. G., and Shmargunov, V. P.: Optical-microphysical properties of smoke haze from Siberian forest fires in summer 2012, Int. J. Remote Sens., 35, 5722-5741, 2014.

Law, K. S., Stohl, A., Quinn, P. K., Brock, C., Burkhart, J., Paris, J.D., Ancellet, G., Singh, H. B., Roiger, A., Schlager, H., Dibb, J., Jacob, D. J., Arnold, S. R., Pelon, J., and Thomas, J. L.: Arctic air pollution: New insights from POLARCAT-IPY, B. Am. Meteorol. Soc., 95, 1873-1895, doi:10.1175/bams-d-13-00017.1, 2014.

Luangjame, J.: Recent Information of the EANET Network Center from the Editor, Eanet Science Bulletin, 3, 3-21, 2013.

Manual AZ-10: Research and Production Division "ECOINTECH", Moscow, available at: http://www.eco-intech.com/ img/AVimg/Brochure/AZ10.pdf (last access: 5 April 2014), 2010.

Menut, L., Flamant, C., Pelon, J., and Flamant, P. H.: Urban boundary-layer height determination from lidar measurements over the Paris area, Appl. Optics, 38, 945-954, 1999.

Menzies, R. T. and Tratt, D. M.: Airborne lidar observations of tropospheric aerosols during the Global Backscatter Experiment (GLOBE) Pacific circumnavigation missions of 1989 and 1990, J. Geophys. Res., 102, 3701-3714, 1997.

Nilsson, E. D.: Planetary boundary layer structure and airmass transport during the International Arctic Ocean Expedition 1991, Tellus B, 48, 178-196, 1996.

Nilsson, E. D., Rannik, U., Swietlicki, E., Leck, C., Aalto, P. P., Zhou, J., and Norman, M.: Turbulent aerosol fluxes over the Arctic Ocean. 2. Wind-driven sources from the sea, J. Geophys. Res., 106, 32139-32154, 2001.

O'Dowd, C. D. and Smith, M. H.: Physicochemical properties of aerosols over the northeast Atlantic: evidence for wind-speedrelated submicron sea-salt aerosol production, J. Geophys. Res., 98, 1137-1149, 1993.

Ohara, T., Akimoto, H., Kurokawa, J., Horii, N., Yamaji, K., Yan, $\mathrm{X}$., and Hayasaka, T.: An Asian emission inventory of anthropogenic emission sources for the period 1980-2020, Atmos. Chem. Phys., 7, 4419-4444, doi:10.5194/acp-7-4419-2007, 2007

Pavlov, A. N., Shmirko, K. A., and Stolyarchuk, S. Y.: Characteristics of structure and dynamics of the planetary boundary layer in the "Ocean-Continent" zone - Part 2: Summer period, Atmos. Ocean. Opt., 26, 285-292, 2013.

Peters, T. M., Ott, D., and O'Shaughnessy, P. T.: Comparison of the Grimm 1.108 and 1.109 portable aerosol spectrometer to the TSI 3321 aerodynamic particle sizer for dry particles, Ann. Occup. Hyg., 50, 1-8, doi:10.1093/annhyg/mel067, 2006.
Pol'kin, V. V. and Golobokova, L. P.: A comparative analysis of aerosol chemical compositions in complex experiments in Primorye, Atmos. Ocean. Opt., 24, 554-565, 2011.

Pol'kin, V. V., Panchenko, M. V., and Golobokova, L. P.: Ion composition of near-water aerosol over White Sea in Augusts of 2003-2006, Atmos. Ocean. Opt., 20, 911-916, 2007.

Polkin, V. V., Panchenko, M. V., Golobokova, L. P., Filippova, U. G., Khodzher, T. V., Lisitzin, A. P., and Shevchenko, V. P.: Aerosols in the marine boundary layer over the White and Kara seas in August-September 2007, in: Contribution of Russia to International Polar Year 2007/08, Meteorological and Geophysical Researches, Paulsen Editions, Moscow, Saint Petersburg, 199214, 2011a (in Russian).

Polkin, V. V., Kozlov, V. S., Turchinovich, Y. S., and Shmargunov, V. P.: Comparative analysis of the microphysical characteristics of aerosol in the marine and coastal areas of Primorye, Atmos. Ocean. Opt., 24, 538-546, 2011b (in Russian).

Ponomareva, V. V., Portnyagin, M. V., and Melnikov, D. V.: Composition of tephra from modern (2009-2011) eruptions of the Kamchatka and Kurile islands volcanoes, HERALD Kamchatka regional organization "Scientific training center", Series: Earth sciences, Earth sciences, 20, 23-37, 2012 (in Russian).

Powell, K., Vaughan, M. A., Winker, D., Lee, K.-P., Pitts, M., and Trepte, C.: Cloud-Aerosol LIDAR Infrared Pathfinder Satellite Observations. Data Management System. Data Products Catalog, National Aeronautics and Space Administration, Langley Research Center, Hampton, Virginia, USA, 23681-2199, 122, 2013.

Radionov, V. F. and Marshunova, M. S.: Long-term variations in the turbidity of the Arctic atmosphere in Russia, Atmos. Ocean, 30, 531-549, 1992.

Radionov, V. F., Marshunova, M. S., Rusina, E. N., LuboLesnichenko, K. E., and Pimanova, Y. E.: Atmospheric aerosol turbidity in polar regions, Izv. Atmos. Ocean. Phy., 30, 797-801, 1994 (in Russian).

Rahn, K. A.: Relative importances of North America and Eurasia as sources of Arctic aerosol, Atmos. Environ., 15, 1447-1455, 1981.

Rasool, S. I.: Chemistry of the Lower Atmosphere, Plenum Press, New York, USA, London, UK, 335 pp., 1973.

Reist, P. C.: Aerosol Scienc and Technology, 2nd Edn., McGrawHill, New York, USA, 379 pp., 1993.

Roiger, A., Thomas, J. L., Schlager, H., Law, K. S., Kim, J., Schäfler, A., Weinzierl, B., Dahlkötter, F., Krisch, I., Marelle, L., Minikin, A., Raut, J.-C., Reiter, A., Rose, M., Scheibe, M., Stock, P., Baumann, R., Bouarar, I., Clerbaux, C., George, M., Onishi, T., and Flemming, J.: Quantifying Emerging Local Anthropogenic Emissions in the Arctic Region: The ACCESS Aircraft Campaign Experiment, B. Am. Meteorol. Soc., 906, 441460, doi:10.1175/BAMS-D-13-00169.1, 2015.

Rudis, D. D.: Alaska Maritime National Wildlife Refuge - Bering Sea Unit Contaminant Assessment, US Fish and Wildlife Service, Juneau Field Office, Alaska, 56 pp., 2010.

Sakerin, S. M. and Kabanov, D. M.: Spatial inhomogeneities and the spectral behavior of atmospheric aerosol optical depth over the Atlantic Ocean, J. Atmos. Sci., 59, 484-500, 2002.

Sakerin, S. M., Kabanov, D. M., Panchenko, M. V., Polkin, V. V., Holben, B. N., Smirnov, A. V., Beresnev, S. A., Gorda, S. Y., Kornienko, G. I., Nikolashkin, S. V., Poddubnyi, V. A., and Tashchilin, M. A.: Monitoring of atmospheric aerosol in the 
Asian part of Russia in 2004 within the framework of AEROSIBNET program, Atmos. Ocean. Opt., 18, 871-878, 2005.

Sakerin, S. M., Kabanov, D. M., Smirnov, A. V., and Holben, B. N.: Aerosol optical depth of the atmosphere over ocean in the wavelength range 0.37-4 $\mu \mathrm{m}$, Int. J. Remote Sens., 29, 2519-2547, doi:10.1080/01431160701767492, 2008.

Sakerin, S. M., Chernov, D. G., Kabanov, D. M., Kozlov, V. S., Panchenko, M. V., Polkin, V. V., and Radionov, V. F.: Preliminary results of studying the aerosol characteristics of the atmosphere in the region of Barentsburg, Spitsbergen, Problemy Arktiki i Antarktiki, 1, 20-31, 2012 (in Russian).

Sakerin, S. M., Kabanov, D. M., Rostov, A. P., Turchinovich, S. A., and Knyazev, V. V.: Sun Photometers for measuring spectral air transparency in stationary and mobile conditions, Atmos. Ocean. Opt., 26, 352-356, 2013.

Sakerin, S. M., Andreev, S. Y., Kabanov, D. M., Nikolashkin, S. V., Prahov, A. N., Radionov, V. F., Turchinovich, Y. S., Chernov, D. G., Holben, B. N., Smirnov, A., and Sorokin, M. G.: On results of studies of atmospheric aerosol optical depth in Arctic regions, Atmos. Ocean. Opt., 27, 517-528, 2014.

Sasakawa, M. and Uematsu, M.: Chemical composition of aerosol, sea fog, and rainwater in the marine boundary layer of the northwestern North Pacific and its marginal seas, J. Geophys. Res., 107, 4783, doi:10.1029/2001JD001004, 2002.

Sharma, S., Lavoue, D., Cachier, H., Barrie, L. A., and Gong, S. L.: Long-term trends of the black carbon concentrations in the Canadian Arctic, J. Geophys. Res., 109, D15203, doi:10.1029/2003JD004331, 2004.

Sharma, S., Ishizawa, M., Chan, D., Lavoué, D., Andrews, E., Eleftheriadis, K., and Maksyutov, S.: 16-year simulation of Arctic black carbon: Transport, source contribution, and sensitivity analysis on deposition, J. Geophys. Res.-Atmos., 118, 943-964, doi:10.1029/2012JD017774, 2013.

Shevchenko, V. P.: The influence of aerosols on the oceanic sedimentation and environmental conditions in the Arctic, Publishing House "Nauka", Moscow, Russia, 226 pp., 2006 (in Russian).

Shevchenko, V. P., Lisitsin, A. P., Vinogradova, A. A., Smirnov, V. V., Serova, V. V., and Stein, R.: Arctic aerosols. Results of tenyear investigations, Atmos. Ocean. Opt., 13, 510-533, 2000.

Shmirko, K. A., Pavlov, A. N., Stolyarchuk, S. Y., Salyuk, P. A., and Bukin, O. A.: Radiative components dynamics at the Far East region, Proceedings of SPIE, 7860, Lidar Remote Sensing for Environmental Monitoring XI, 78600S, 11 November 2010, doi:10.1117/12.869619, 2010.

Shmirko, K. A., Pavlov, A. N., Stolyarchuk, S. Y., Mayor, A. Y., and Bukin, O. A.: Typical patterns of PBL structure and dynamics in transitional ocean-continent zone in summer and winter in Far East region, Proceedings of SPIE, 8526, Lidar Remote Sensing for Environmental Monitoring XIII, 85260U, 19 November 2012, doi:10.1117/12.977387, 2012.

Sievering, H., Boatman, J., Luria, M., and Valin, C. C.: Sulfur dry deposition over the western North Atlantic: the role of coarse aerosol particles, Tellus B, 41, 338-343, 1989.

Smirnov, V. V., Savchenko, A. V., Pronin, A. A., Kuusk, V. V., and Radionov, V. F.: Variability in aerosol and air ion composition in the Arctic spring, Atmos. Res., 49, 163-176, 1998.

Stohl, A., Andrews, E., Burkhart, J. F., Forster, C., Herber, A., Hoch, S. W., Kowal, D., Lunder, C., Mefford, T., Ogren, J. A., Sharma, S., Spichtinger, N., Stebel, K., Stone, R., Ström, J., Tørseth, K.,
Wehrli, C., and Yttri, K. E.: Pan-Arctic enhancements of light absorbing aerosol concentrations due to North American boreal forest fires during summer 2004, J. Geophys. Res., 111, D22214, doi:10.1029/2006JD007216, 2006.

Stohl, A., Klimont, Z., Eckhardt, S., Kupiainen, K., Shevchenko, V. P., Kopeikin, V. M., and Novigatsky, A. N.: Black carbon in the Arctic: the underestimated role of gas flaring and residential combustion emissions, Atmos. Chem. Phys., 13, 8833-8855, doi:10.5194/acp-13-8833-2013, 2013.

Stone, R. S., Anderson, G. P., Shettle, E. P., Andrews, E., Loukachine, K., Dutton, E. G., Schaaf, C., and Roman III, M. O.: Radiative impact of boreal smoke in the Arctic: Observed and modeled, J. Geophys. Res., 113, D14S16, doi:10.1029/2007JD009657, 2008.

Stone, R. S., Sharma, S., Herber, A., Eleftheriadis, K., and Nelson D. W.: A characterization of Arctic aerosols on the basis of aerosol optical depth and black carbon measurements, Elementa, Science of the Anthropocene, 2, 000027, doi:10.12952/journal.elementa.000027, 2014.

Streets, D. G. and Waldhof, S. T.: Present and future emissions of pollutants in China: $\mathrm{SO}_{2}, \mathrm{NO}_{x}$ and $\mathrm{CO}$, Atmos. Environ., 34, 363-374, 2000.

Sun, J.: Soluble Species in Aerosols Collected on the Route of the First Chinese National Arctic Research Expedition, J. Glaciology and Geocryology, 24, 744-749, 2002.

Tomasi, C., Vitale, V., Lupi, A., Di Carmine, C., Campanelli, M., Herber, A., Treffeisen, R., Stone, R. S., Andrews, E., Sharma, S., Radionov, V. F., von Hoyningen-Huene, W., Stebel, R., Yansen, G. H., Myhre, C. L., Wehrli, C., Aaltonen, V., Lihavainen, Y., Virkkula, A., Hillamo, R., Ström, J., Toledano, C., Cachorro, V. E., Ortiz, P., de Frutos, A. M., Blindheim, S., Frioud, M., Gausa, M., Zeielinski, T., Petelski, T., and Yamanouchi, T.: Aerosol in polar regions: a historical overview based on optical depth and in situ observations, J. Geophys. Res., 112, D16205, doi:10.1029/2007JD008432, 2007.

Tomasi, C., Lupi, A., Mazzola, M., Stone, R. S., Dutton, E. G., Herber, A., Radionov, V. F., Holben, B., Sorokin, M., Sakerin, S. M., Terpugova, S. A., Lanconelli, C., Petkov, B., and Vitale, V.: An update of the long-term trend of aerosol optical depth in the polar regions using POLAR-AOD measurements performed during International Polar Year, Atmos. Environ., 52, 29-47, 2012.

Toyama, K., Zhang, J., and Satake, H.: Long-range transportation and deposition of chemical substances over the Northern Japan Alps mountainous area, Geochem. J., 47, 683-692, 2013.

Troen, I. and Mahrt, L.: A simple model of the atmospheric boundary layer: Sensitivity to surface evaporation, Bound.-Lay. Meteorol., 37, 129-148, 1986.

Tsunogai, S., Saito, O., Yamada, K., and Nakay, S.: Chemical composition of oceanic aerosol, J. Geophys. Res., 77, 5283-5292, 1972.

Twomey, S.: The influence of pollution on the shortwave albedo of clouds, J. Atmos. Sci., 34, 1149-1152, 1977.

Vinogradova, A. A.: Seasonal and long-term variations in atmospheric circulation indices and air mass transport to the Russian Arctic, Atmos. Ocean. Opt., 27, 463-472, 2014 (in Russian).

Vinogradova, A. A. and Ponomareva, T. Y.: Sources and sinks of anthropogenic microelements in the Arctic atmosphere: tendencies in variations from 1981 to 2005, Atmos. Ocean. Opt., 20, 433-441, 2007. 
Vinogradova, A. A. and Veremeichik, A. O.: Model estimates of anthropogenic black carbon concentration in the Russian Arctic atmosphere, Atmos. Ocean. Opt., 26, 443-451, 2013 (in Russian).

Vogelezang, D. H. P. and Holtslag, A. A. M.: Evaluation and model impacts of alternative boundary-layer height formulations, Bound.-Lay. Meteorol., 81, 245-269, 1996.

Wang, Q. and Wang, S.: Turbulent and thermodynamic structure of the autumnal Arctic boundary layer due to embedded clouds, Bound.-Lay. Meteorol., 113, 225-247, 2004.

Wang, Q., Jacob, D. J., Fisher, J. A., Mao, J., Leibensperger, E. M., Carouge, C. C., Le Sager, P., Kondo, Y., Jimenez, J. L., Cubison, M. J., and Doherty, S. J.: Sources of carbonaceous aerosols and deposited black carbon in the Arctic in winter-spring: implications for radiative forcing, Atmos. Chem. Phys., 11, 1245312473, doi:10.5194/acp-11-12453-2011, 2011.

$\mathrm{Xu}, \mathrm{G}$. and Yuan Gao, Y.: Atmospheric trace elements in aerosols observed over the Southern Ocean and coastal East Antarctica, Polar Res., 33, 23973, doi:10.3402/polar.v33.23973, 2014.

Xu, J., Sun, J., Ren, J., and Qin, D.: Soluble Species in the Aerosols Collected on the Route of the Second Chinese National Arctic Research Expedition, Journal of Glaciology and Geocryology, 27, 205-212, 2005.
Yli-Tuomi, T., Venditte, L., Hopke, P. K., Basunia, M. S., Landsberger, S., Viisanen, Y., and Paatero J.: Composition of the Finnish Arctic aerosol: collection and analysis of historic filter samples, Atmos. Environ., 37, 2355-2364, 2003.

Zhan, J., Gao, Y., Li, W., Chen, L., Lin, H., and Lin, Q.: Effects of ship emissions on summertime aerosols at $\mathrm{Ny}$-Alesund in the Arctic, Atmospheric Pollution Research, 5, 500-510, 2014.

Zhang, L., Brook, J. R., and Vet, R.: A revised parameterization for gaseous dry deposition in air-quality models, Atmos. Chem. Phys., 3, 2067-2082, doi:10.5194/acp-3-2067-2003, 2003.

Zilitinkevich, S. and Esau, I.: Planetary boundary layer feedbacks in climate system and triggering global warming in the night, in winter and at high latitudes, Geography, Environment, Sustainability, 1, 20-34, 2009. 